\title{
Places of Pain and Shame: Adaptive Reuse of Negatively Connotated Places
}

By

Gemma Winstanley

\author{
A 120 point thesis \\ submitted to the Victoria University of Wellington \\ in partial fulfilment of the requirements for the \\ Master of Architecture (Professional)
}

Victoria University of Wellington

School of Architecture 



\begin{abstract}
Our landscape is a patchwork of scars, remnants of a painful past. A range of homes, sites and institutions with a history of confinement, racial discrimination or an involvement in war, massacre and genocide. These places, which often walk the thin line between our constant need to remember and the overwhelming urge to forget, often invoke pain, shame, guilt and ultimate futility because of the events that occurred and the ideologies they represent.

These places, defined here as negative heritage - conflictual sites that become the repository of negative memory in the collective imaginary, have become prolific the world over as we redefine what inheritance we preserve in our landscape for current use and to pass on to future generations. What this suggests is that, with the passing of time, what we consider to be heritage can become highly malleable - shaped to fit the parameters of local or national value systems and perceptions of identity.

The aim of this thesis is to examine the political, cultural or social conditions attributed to these stigmatised spaces that enable one site to be reused while another is condemned. It asks how does this influence of collective memory and perception affect how we design for the possible reuse of these sites?

The findings of this research inform the design of a process for the adaptive reuse of some of our most potent places of pain and shame. The development of this process drew on the specific history of memory, erasure and preservation in the architecture of Levin's dilapidated Kimberley Centre, once New Zealand's largest state-run institution. The process will allow for the development of strategies for managing stigmatised spaces, where the tendency to obliterate traumatic sites, whether materially or psychologically, must be rationalised with an effort to frame architecture as containers of sets of events, a multifaceted collection of histories in context.
\end{abstract}





\section{Acknowledgements}

To my supervisor, Christine McCarthy, for your knowledge and expertise on heritage and architecture and the inspiring effect it had on this portfolio. I am immensely appreciative of your constant encouragement and moulding of this, at times harrowing research, into this book.

To my friends and colleagues for providing distraction and laughter and for making sure I never lost sight of my passion during all the highs and lows of this research, thank you for going through this with me.

And to Ma and Pa Winstanley, who without, none of this would be possible, thank you, for just, everything.

An early version of Chapter 2 , the case study analysis and methodological approach was presented at the Place of Memory and Memory of Place Conference at Cambridge University in October 2017. 



\section{Contents}

Abstract

Acknowledgements

iii

List of Illustrations

1. Introduction

Aims \& Objectives

Methodology

2. Literature Review

History and The Forming of Heritage 5

Negative Heritage \& The Heritage of Atrocity 6

The Management of Negative Heritage 8

Consuming Negative Heritage or Dark Tourism 10

3. Case Study Review 13

Methods 14

Case Studies - Categories Analysis 16

Analysis: Building Types $\quad 45$

Analysis: Site Management $\quad 51$

Feasibility 58

4. Design Process 59

Design Process 60

Stage 1: Case Study Analysis 63

Stage 2: Site Analysis 65

Kimberley Centre $\quad 67$

5. Design Test 79

Stage 3: Design Test 81

Design Brief 83

Erasure Techniques 84

Layering Process 86

Initial Design 88

6.Conclusion 101

Reference List 109

Appendix A: Case Study Data 113

Appendix B: Erasure Techniques 189 



\section{List of Illustrations}

Images were produced by author unless otherwise indicated

Page 2 - Fig. 1 - Kimberley Centre - Former Air Force Barracks

Page 58 - Fig. 2 - Site Usability Evaluation Diagram

Page 62 - Fig. 3-5 - Draft Design Process Diagram

Page 69 - Fig. 6 - Kimberley Centre - Former Air Force Barracks

Page 71 - Fig. 7 - Levin - Aerial Image

- LINZ Data Service, https://data.linz.govt.nz/set/4702-nz-aerial-imagery/, Downloaded 07.11.17

Page 73 - Fig. 8 - Aerial Site Plan

- Drawn by Author, adapted from LINZ Aerial Image, LINZ Data Service, https://data.linz.govt.nz/set/4702-nz-aerial-imagery/, 07.11.17

Page 75 - Fig. 9 - Kimberley Centre - Monowai Ward

Page 78 - Fig.10 - Master Plan - Identity

Page 79 - Fig. 11 - Ward 7 Floor Plan

- Authors own Image, adapted from original Ministry of Works drawings provided by Horowhenua District Council. 21.11.17

Page 88 - Fig. 14 - Erasure Techniques - Abandonment, Burning - Axonometric

Page 89 - Fig. 14.1 - Erasure Techniques - Entombment, Filling in, Demolition, Re-Surfacing - Axonometric

Page 90 - Fig. 15: - Layering in Plan

Page 91 - Fig. 16 - Layering in Section

Page 93 - Fig.17 - Initial Design

Page 95 - Fig. 18 - Site Plan

Page 97 - Fig. 19 - Sleep Therapy Clinic - Plan, Elevation, Section

Page 99 - Fig. 20 - Substance Abuse Clinic - Plan, Elevation, Section

Page 101 - Fig. 21 - Depression and Anxiety Counselling Centre - Plan, Elevation, Section

Page 103 - Fig. 22 - Personality and Mood Disorder Clinic - Plan, Elevation, Section 



\section{Introduction}

Our heritage landscape is different than it was half a century ago. Despite the argument that heritage is selected 'to celebrate the past and bolster the present', sites representing the legacy of a painful past have become a common part of our heritage vernacular ${ }^{1}$. Heritage, once overwhelmingly concerned with protecting the great and beautiful creations of the past, is now just as concentrated on the reverse, the destructive and cruel side of history.

However determining the point when memories can be allowed to fade, memorialisation end, and life continue on a site is complex and difficult. In practice pain and shame has seen the destruction of horror houses, the creation of prison museums, the desecration of graves, the removal of statues and intense public debate on reconstruction and the placement of memorials. Collective memory and the reverberation of certain events in the public discourse mean that some sites are so potent with memory that they cannot be rehabilitated and put back to use. Other sites, while invoking a strong reaction, may be able to be put back to use with the right level of social and political involvement. In this thesis, I aim to diagnose what political, social and cultural conditions allow for some sites to be reused while others are erased and how this knowledge can inform a design process for the adaptive reuse of negatively connotated places.

While literature on trauma, memorialization, memory and heritage is vast and will underpin much of this research, the lack of work that highlights the consequences for reuse that traumatic or negative associations have on architecture will guide the focus of this thesis. This research marries the vast psychological and anthropological literature on heritage preservation with architectural reuse discourse, and addresses the potential conflict between the compulsion to preserve the historic and obliterate the traumatic. 


\section{Aims \& Objectives}

This research sets out to explore and understand the ethics, socio-politics, cultural dissonances and perceptions of traumatic and shameful memory inherent to places of negative heritage that lead to either its preservation, demolition, memorialisation or conversion to a new use.

The aim is to use this understanding to design a process for the adaptive reuse of places of pain and shame. The process will consider the fading and rejuvenation of collective memory over time as a key driver when assessing the potency of material remnants of sites, what they may be reused for, and how design can ease the process between obsolescence and usability.

\section{Methodology}

This project uses collected data, identification of erasure techniques and drawing methods to develop a design process, using the Kimberley Centre site as fertile ground to test these processes and techniques. The analysed case study data is a central reference point to reading this thesis. It is initially used to inform the literature review and then as a point of reference for the process design, site selection and thesis reflection, grounding the process and test design to derive feasible design techniques, processes and outcomes.

Case studies and past practice are used to establish patterns and correlations between conditions present on various sites and their final architectural outcomes. The analysis allows an understanding of how the conditions present on a site such as building type and event lead to a particular architectural outcome and the various ways that this may manifest.

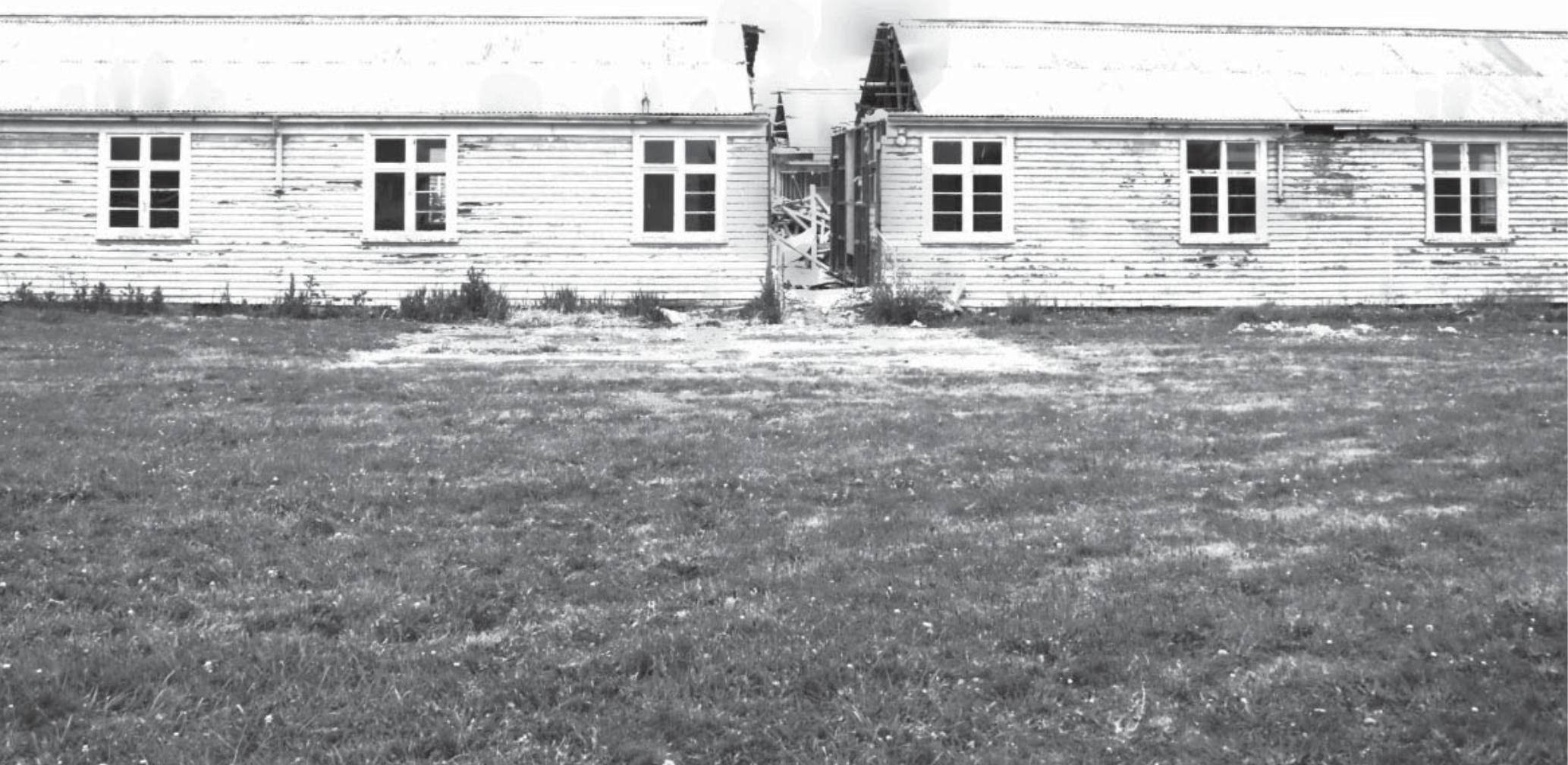


The analysis identifies patterns and themes that form a basis for the design process that allows a stigmatised space to be rehabilitated in the public eye and put to a new use. The analysis reveals various physical mechanisms for the erasure of memory. These are developed to inform an iterative design process on the test site (The Kimberley Centre,) which juxtaposes erasure and preservation by layering the new function over the action of the erasure of negative memory. This process is both an evidence-based reflection on current practice and a mechanism to engage proactively with negative heritage

The architecturalising of various stages of the design process will allow the critical reflection of these management strategies for stigmatised spaces, where the tendency to obliterate traumatic sites, whether materially or psychologically, must be rationalised with the effort to frame architecture as a container of sets of events, a multifaceted collection of histories in context.

\section{Thesis Outline}

The thesis is divided into six chapters, 1. Introduction, 2. Literature Review, 3. Case Study Review, 4. Design Process, 5. Design Test and 6. Conclusion.

The literature review situates this research in the current context of how heritage and memory are understood and how heritage places are managed and used. It uses the current literature to define the types of sites that will be selected as case studies and the ways that these sites can be measured and compared, considering how these sites have been managed and used in the past.

Chapter three analyses the case study data (which is located in Appendix A). The analysis feeds into a discussion of the management of these sites, and how the building type, event and site outcome influence how types of negative heritage sites have been managed over time.

Chapter four documents the development of a draft design process. This process is then tested on the Kimberley Centre site in Levin. This testing of the process is continued in chapter five with the development of a brief to create an initial design proposal.

In chapter six I conclude by analysing the applicability of the design experiment to other sites. I will use this analysis to discuss how management of negative heritage sites might bridge the gap between obsolescence and usability. 



\section{Literature Review}

The design and adaptive reuse of stigmatised space is an under researched area of modern heritage discourse. In order to understand how these places have been defined, managed and used, a large cross section of literature across subjects such as psychology, geography, history and architecture has been reviewed within the scope of heritage, trauma, memorialization and memory. The aim of the first section of this literature review is to define heritage, how it is formed, changed and perceived. The second section connects this to negative heritage, how it is characterised and defined in the literature and its rise to prominence. This section will also be used to define negative heritage and therefore identify sites to be included in the case study analysis in chapter three. The final two sections of the literature review will analyse how stigmatised space has been managed and used, considering memorialization and demolition, as well as the rise of dark tourism as an industry which can make these sites economically viable to reuse.

\section{History \& The Forming of Heritage}

A modern culture that promotes civic engagement with memory and identity has seen the mass preservation of sites of cultural heritage collected together in recent history to form a piecemeal landscape of things identified as being worth remembering. Monuments, city quarters and landscapes with historically meaningful 'clout' make up an ever greater proportion of the physical environment'. As Lynn Meskell puts it, 'the material world is a constant reminder of an ever present past and yet certain decisions by particular individuals and organisations render particular places as valuable, important, aesthetic and meaningful. Heritage inhabits spatial, temporal, cultural and economic domains'2.

However heritage is more than merely places and things, but, is also as Smith argues, 'an intangible process in which social and cultural values are identified, negotiated, rejected or affirmed'3. By conceptualising heritage as a socially contested process we can see how contemporary perceptions and needs come to influence the past, and how heritage is defined and managed in the present. Heritage in context has the ability to be continuously constructed and reconstructed beyond its physical elements by the communities and individuals it belongs to. 
Tunbridge and Ashworth in Dissonant Heritage state that 'all heritage is someone's heritage and that someone determines that it exists's. Although both history and heritage make selective use of the past for current purposes, and transform the past through interpretation, heritage is a product of the present purposefully developed in response to current demands and shaped by current requirements ${ }^{5}$. As Tunbridge and Ashworth explain, 'the present selects an inheritance from an imagined past for current use and decides what should be passed on to an imagined future'6. 'Heritage', by this definition, is locally defined and highly malleable - shaped to fit the parameters of local or national value systems and perceptions of identity. By interacting with their heritage, a community continuously creates and refines cultural identity, meaning and memory?

What this suggests is that what constitutes heritage is neither static nor predictable. It is a continuous negotiation with the tangible and intangible past. This heritage is not always rose-tinted, not always an uplifting accumulation of memories. On the contrary it can be made up of the consequences of violence, destruction, and death that, for an abundance of reasons, people feel the need to monumentalize. As Joshi and Ballal state in their article on the 'Bhopal Gas Tragedy', 'to view history as a sanitised, linear, celebratory narrative is an insular, elitist perspective that inhabits the present and prevents us from engaging with the past's.

\section{Negative Heritage \& the Heritage of Atrocity}

Sites with a negative cultural association, which will be known in this thesis as 'negative heritage', have been assimilated into the global framework of heritage places $^{9}$. Trinidad Rico defines negative heritage as sites that may be interpreted by a group as commemorating conflict, trauma and disaster, while Meskell identifies it as:

Conflictual sites that become the repository of negative memory in the collective imaginary. As a site of memory, negative heritage occupies a dual role: it can be mobilized for positive didactic purposes or alternatively be erased if such places cannot be culturally rehabilitated and thus resist incorporation into the national imaginary ${ }^{10}$.

Many other authors are hesitant to use the term 'negative' however, for fear of invoking the existence of a positive heritage. Sharon Macdonald uses the term 'difficult heritage' and defines it in her book of the same name as:

A past that is recognised as meaningful in the present but that is also contested and awkward for public reconciliation with a positive, self-affirming contemporary identity. Difficult heritage may also be troublesome because it threatens to break through into the present in disruptive ways, opening up social divisions, perhaps by playing into imagined, even nightmarish futures ${ }^{11}$.

In the literature, sites with negative associations are characterised by an array of other terms including 'sites of conscious', 'dark histories', 'death spaces' or 'ambivalent' 'ambiguous' or 'dissonant heritage"12.

\footnotetext{
4 Tunbridge \& Ashworth, 1996, p. 57

5 Meskell, 2002, p. 570

6 Tunbridge \& Ashworth, 1996, p. 6

7 Field-Murray, et al. 2011, p. 469

8 Joshi \& Amritha, 2012, p. 11

9 Rico, 2013, p. 346

10 Meskell, 2002, p. 570

11 Macdonald, 2009, p. 1

12 See, Chadha 2006; El Richani 2015; McAtackney 2014, Tunbridge \& Ashworth 1996, Burstrom \&

Gelderblom 2011; and Anderson 2006
} 
Negative heritage has over time become highly malleable coming to serve a variety of purposes in contemporary society such as educational, didactic or symbolic ${ }^{13}$. In 2016 Macdonald asked 'Is Difficult Heritage still Difficult?' She describes a 'fundamental - though far from universal' shift in how national identity is performed in relation to troubling pasts ${ }^{14}$. An idea has formed that confrontation of a troubling past can have an educative value and could in fact have an inoculation effect. There is an increased willingness by nations and cities to define their ongoing identities through their difference from the past rather than through 'predominantly continuity seeking temporal narratives' ${ }^{\prime 15}$. This is not to say that negative histories were ignored before, but rather that they were regarded as an interruption to the continuity of identity and negotiated around. To face your difficult history is now understood as a sign of openness and honesty, an unwillingness to confront it, a moral failing. This has lead to a global rush to commemorate places of atrocity ${ }^{16}$.

Ultimately heritage and particularly negative heritage lives in a temporal dimension. It constantly operates, as Meskell describes, between 'the dual poles of transformation and erasure' depending on the social and temporal context ${ }^{17}$.

\section{Heritage of Atrocity}

Tunbridge and Ashworth in Dissonant Heritage identify a range of atrocities that can carry material remnants and therefore negative heritage. These are:

(a) - Atrocities arising from the aggravation of natural or accidental disaster by alleged human action or neglect

(b) - Atrocities interpreted as being perpetrated by an entire category of people on another entire category. This definition encompasses colonialism, racism, and sexism in which all members of one country, race, or gender are generally victims or perpetrators

(c) - Atrocities arising from war or within the context of war, though determining when the horrors inherent of war become atrocities is difficult

(d) - Atrocity perceived to have existed in former judicial systems

(e) - Atrocities arising from large-scale killing or massacre

(f) - Atrocities that can be placed in the most extreme category of genocide, as a deliberate act or policy to eradicate not just a culture but a people ${ }^{18}$.

Sites defined by these types of atrocities could include sites of confinement, torture, murder or mass death and of cultural or social death which could encompass prisons, battlefields, death camps, graveyards, infamous death sites and sites of extraordinary disasters. Tunbridge and Ashworth also identify a number of characteristics of the heritage of atrocity that allow it to be recognised and remembered by contemporary communities and nations:

(a) - The nature of the cruelty perpetrated, favouring the unusual or spectacular over the commonplace; the more memorable and shocking an event, rather than the more effective it is at eradication of its victims, the greater its deployment, invocation and appropriation as heritage.

13 Langenbach, 1992, p. 177

14 Macdonald, Is 'Difficult Heritage' still 'Difficult'?, p. 7

15 Macdonald, 2009, p. 189

16 Macdonald, Is 'Difficult Heritage' still 'Difficult'?, p. 19

17 Meskell, 2002, p. 570

18 Tunbridge \& Ashworth, 1996, p. 96 
(b) - The nature of the victims, namely their innocence, vulnerability, and noncomplicity in the violence; victims suspected of complicity with or provocation of their aggressors elicit an utter lack of sympathy. The number of victims has little influence on deployment of heritage; the nature of human imagination is such that it resists the extension of empathy beyond small groups.

(c) - The nature of the perpetrators as an unambiguously identifiable, distinguishable group, different from their victims and from the observer for whom the event is interpreted. An effective tactic in the deployment of an event as heritage is the demonization of the perpetrator to prevent identification of the observer with the perpetrator, who is often portrayed as unlike the observer or, ideally, as not normal, or alternatively as quiet, invisible or unexpected, unnerving the observer.

(d) - The high-profile visibility of the original events and its effective promotion, rather than documentation and verification. While modern technologies do extend the range and impact of events, there remains a possibility of 'sympathy fatigue' on the part of an audience bombarded with images and news of such events.

(e) - Survival of the record. Perpetrators often attempt eradication of evidence, either as part of a campaign of annihilation or out of fear of retribution ${ }^{19}$.

The interpretation of one or many of these characteristics has the ability to affect the usability of the site and therefore how it might be managed and used by a government, community or individual intending to tell a particular narrative.

\section{The Management of Negative Heritage}

In Shadowed Ground, geographer Kenneth Foote offers four management strategies for sites in the aftermath of violent or tragic events: obliteration, sanctification, designation and rectification ${ }^{20}$.

Obliteration follows events that Foote defines as 'shameful'. Obliteration involves effacing all evidence of a tragedy from a site; the site not just cleaned, but scoured and removed from use. After an appropriate period of time it might be returned to an entirely new use. Foote notes, however, that obliteration subverts the cathartic release of emotion that is part of the ritual of sanctification. Obliterated sites, once stigmatized, tend to stand out as much as sacred spaces, 'indefinite scars' on the landscape, a rupture of sorts that breaks the texture of the landscape. A key point is that the obliteration process can never be complete. When abandoned or effaced 'these shamed places maintain an emphatic hold on our attention, just the opposite of what was intended'21.

Sanctification is the formal dedication of a site in commemoration of a martyr, heroic figure, or victim of violence, usually when the event involves heroism or self-sacrifice. It is what occurs if all of Tunbridge and Ashworth's characteristics of the heritage of atrocity are in place. The event must be public and touch a single, homogeneous, self-identified group in order for the group to experience a shared loss and engage in sanctification. Within the mechanism of sanctification a direct link between landscape and commemoration is drawn; these sites taking on a distinct appearance.

In Designation a site is marked for its significance but does not undergo the same ritual of consecration as sanctification. Designation often follows what Foote terms 'the unforgettable event', one which would urge obliteration were it not highly atypical. In this event, loss is neither specific enough to a uniform population, nor heroic enough, to warrant sanctification. 
Sanctification and Designation create places that tend to take on the contemporary purposes of negative heritage as: educational, didactic and symbolic ${ }^{22}$. These sites, as both Foote and Langenbach note, are not preserved for their aesthetic qualities but for their symbolic value. Langenbach also argues that cities without these symbolic monuments are impersonal and unable to express feeling ${ }^{23}$. He is extremely critical of environmental professionals who are not aware of the symbolic content of the environment stating that:

Professionals see the environment as a physical entity, a functional container, a setting for social action or programs, a pattern of land uses, a sensuous experience, but seldom a social or political symbol. Designers often 'restore' buildings and sites to an idealized past or emphasize the artistic qualities of an artefact over its didactic or symbolic attributes. The conservation of negative monuments goes against the grain. And, preserving the monuments of an embarrassing or evil past flies in the face of one of the basic tenets of modernism: the goal of architectural design should be to improve the quality of life by improvement of the environment ${ }^{24}$.

This leads to Foote's final management strategy, rectification. Rectification involves a literal or figurative sanitization that facilitates the disassociation of place and event in order to allow the site to experience reclamation and reuse. The site is essentially exonerated from the atrocity or 'restored to an ideal past' as Langenbach puts it, the associations eventually weakening, the notoriety only temporary before being reintegrated. Rectification generally follows a tragic event that is accidental, or violence that is interpreted as senseless. The location of the event is seen as merely a product of chance and ultimately blameless.

What Foote points out is that the perceptions of cause and blame around an event and its societal context are critical to understanding the treatment of a place following an atrocity ${ }^{25}$. Foote's spectrum is interesting from a preservation point of view, through mention of exoneration of place and the implication of architecture in the tragic events that buildings host. However, Foote's chosen terminology of definitions paints a very black and white binary between razing and memorialising sites and does not anticipate the grey area that is adaption and renovation and the perception of the building in the case of adaptive reuse.

\section{Consuming Negative Heritage or 'Dark Tourism'}

Dark Tourism is the practice of visiting places of negative heritage. Its growth into an economically viable industry has, arguably, saved many sites from obliteration ${ }^{26}$. Dark Tourism, however is a controversially potent term. Sharpley suspects that 'dark tourism' has become 'a fashionable and emotive' term that perhaps 'oversimplifies a complex, multi-faceted and multi-dimensional phenomenon', which Tarlow defines as 'visitations to places where tragedies or historically noteworthy death has occurred and that continue to impact our lives'. This may include the visitation to memorials, monuments, museums or even abandoned or returned to use sites remembered under tragic circumstances ${ }^{27}$. It is important to understand, that 'the nature of the heritage product is determined by the requirements of the consumer, not the existence of the resources'; its interpretation relies largely on how it can be marketed, to victims, to the community and to tourists alike ${ }^{28}$.

22 Langenbach, 1992, p. 178

23 Langenbach, 1992, p. 178

24 Langenbach, 1992, p. 178

25 Foote, 1997, p. 180

26 Strange \& Kempa, 2003, p. 388

27 Sharpley, 2005, p. 220; Tarlow ,2005, p. 48

28 Tunbridge \& Ashworth, 1996, p. 9 
Whether the term 'dark tourism' is appropriate or not, it has been the most commonly used term to characterize the capitalization of negative heritage since Lennon and Foley's Dark Tourism, published in 2000, and so it will continue to be used here. Lennon and Foley argue that the relations between touring and death have changed since the end of World War I, such that dark tourism 'is both product of circumstances of the later modern world and a significant influence upon those circumstances' 29 .

It remains unclear as to whether the dark tourism phenomenon is attraction-supply driven or indeed consumer-demand driven ${ }^{30}$. Seaton argues that 'dark tourism' is not a modern phenomenon at all but is rather linked to practices in the thanatopic tradition, part of western religious and philosophical thought. 'Tourism' since the middle-ages for example, has included pilgrimages to places where saints became martyrs. However Seaton does not question the role of media as central to growth in tourism to sites associated with death, by increasing the 'geographical specificity' of murder and violent death and broadcasting it into people's living rooms around the world $^{31}$. The literature suggests that supply and demand have worked in tandem for half a century to produce the industry we have today. The mass decommissioning of negative heritage sites has created a booming supply of dark tourism sites, and the mass consumption of death and violence, through the media and popular culture, has given rise to a socially-sanctioned engagement with these sites that might have once been neglected to the point of destruction.

\section{'Shades of Darkness'}

The ethical issues surrounding the exploitation of tragedy also tend to be most prevalent when blurred with the commercial ethos of the tourism industry. Despite the main draw of dark tourism products being a highly emotional and politicallycharged heritage product - easy to market yet tricky to interpret, some commentators suggest the heritage sector in general is an inappropriate, and even immoral, vehicle for the presentation of death and human suffering. Macdonald in particular calls for more attention to be paid 'to the authorial intention and authenticating devices at work in heritage sites'32. The sanitization or inauthentic elements of 'dark tourism products' are often controlled by the political and cultural climate as much as consumer and aesthetic tastes. As new 'files of representation' lend moral meanings to sites of death, their interpretation can also change, leading to stages of site development and changing 'shades of darkness'.

Miles argues that there is a distinction between 'dark' and 'darker' tourism. Based on the temporal dimension and spatial affinity with the event, he proposes that there is a crucial difference between sites associated with death and suffering, and sites that are of death and suffering ${ }^{33}$. He also argues that dark tourist sites must engender a degree of empathy between the sightseer and the victim, and that sites with an amplified spatial affinity and closer temporal dimension will add to the empathy of visitors, consequential to how the product is perceived, produced and ultimately consumed. This argument is similar to that of Meskell's when it comes to the influence that the temporal dimension has on the interpretation of sites of negative heritage and where they exist between the poles of transformation or erasure, whether they are 'dark' or 'darker'34. Stone and Sharpley point out this means the interpretation of sites of negative heritage is fluid and conditional on contextual developments and the eroding capabilities of the temporal dimension ${ }^{35}$.

29 Lennon \& Foley, 2000, p. 9

30 Sharpley, 2005, n.p.

31 Seaton, 1996, p. 235

32 Macdonald, A People's Story: Heritage, Identity and Authenticity 1997, p. 156

33 Miles, 2002, p. 1176

34 Meskell, 2002, p. 558

35 Stone \& Sharpley, 2008, p. 589 
This growth of a tourism market specifically dedicated to sites of atrocity and negative memory, the increasing recognition of this memory in the public sphere and the subsequent motivation of developers, local and national governments and individuals to manage and harness their negative pasts for not only commercial ventures but as a way to shape a national identity and absolve a place of guilt, provides a number of parties of interest for this thesis.

\section{Conclusion}

The review of current literature provides the background to a constantly changing understanding of not only what is negative heritage, but how it is interpreted, managed and used. This allows us to consider how a future adaptive reuse project may be used and how it will need to be filtered and analysed in order to decide whether a site can be adaptively reused or simply obliterated or sanctified. Important to this is the idea that heritage is a malleable product, with the perceptions around a site subject to change, to be constantly redefined by the surrounding community. A mechanism of any design process for these sites will have to allow for these constantly changing interpretations. 



\section{Case Study Review}

This chapter presents an analysis of negative heritage sites in order to understand the different aspects of sites that 'are of' negative memory, distinguishing a site that was demolished from one that was reused and identifying the different methods of erasure that take place on different types of sites ${ }^{1}$.

The sites for this analysis were identified using Tunbridge and Ashworth's definitions of atrocities and the characteristics that make these sites effective at recognising and remembering negative memory. These sites have been associated with natural or accidental disaster, flawed judicial processes, or with acts perpetrated by an entire category of people on another entire category of people. They might also be associated with war, massacres or genocide (See p8 of the literature review for full definitions of these). Sites with these associations and memories include, prisons, battlefields, death camps, graveyards, infamous death sites and sites of extraordinary disasters. The events that occurred were also considered for the nature of the cruelty perpetrated (favouring the unusual or spectacular), the nature of the victims (favouring the innocent), the nature of the perpetrators (favouring an unambiguously identifiable individual or group), the visibility of the event and the survival of the record or lack thereof (See the diagram on p14 for the full detail of the site selection process).

The analysis derived four categories of site outcomes for negative heritage sites. The definition of each category was kept broad in order to encompass a wide range of sites. The four categories are: razed, abandoned, returned to use and new use.

This chapter presents the analysed data using qualitative content analysis to evaluate the various case studies ${ }^{2}$. The original data set for each site can be found in Appendix A. A qualitative approach has been used for this research in preference to a basic or interpretive approach because identifying patterns or irregularities within the categories is the main goal of the analysis. This method goes beyond just data collection but undertakes a full contextual analysis, analysing not just 'what happened?' but also 'why?' aiming to discern a pattern between the event and the context in order to identify categories of buildings, whether this be geographical, by building type or by socio-economic factors and to summarize themes running through the case studies in order to highlight key data and values that may be taken to further research and design.

The chapter is broken up into three sections with the data first being analysed by site outcome and patterns and irregularities being identified within the original designated category. Considering these patterns the sites are then analysed by building type, considering how the original building use changes how the building is treated in the wake of a negative event. The management of the site overall is then considered in section three, analysing patterns between original use, event, outcome and final use.

\footnotetext{
1 Miles, 2002, p. 1176

2 'Qualitative Content Analysis is a set of techniques for the systematic analysis of texts of many kids addressing not only content but also the themes and core ideas found in texts as primary content' (Kohlbacher 2006, 3)
} 


\section{Method for Identifying Sites that 'are of' Negative Heritage}

Sites were identified based on Tunbridge and Ashworth's definitions of atrocities that carry material remnants (p8). Sites that were used as examples in the literature review were used to build a basis for the data selection. Sites were then found by searching for them through sources and search engines using the below key words. Sites were also suggested by supervisors and colleagues and taken from mass media and news reports. This would have generated about half of the initial data list.

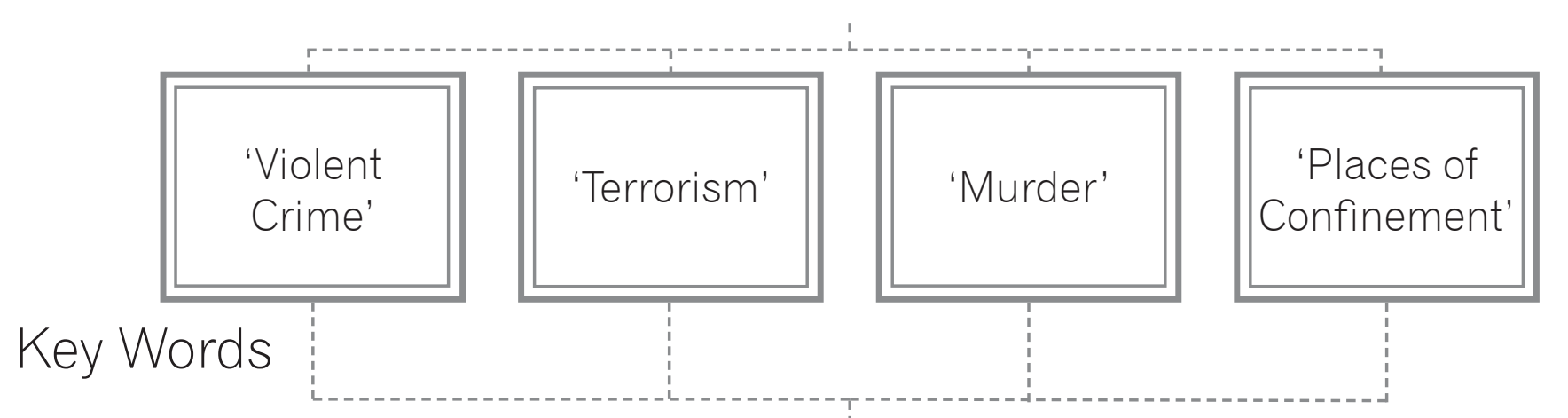

A range of different places, events, time periods and building types needed to be drawn from in order to create a comprehensive overview. Places that were too similar were filtered out of the data set and replaced by those that offered a slightly different set of data to compare.

\section{'Notoriety'}

\&

Media Interest

Association between Place \& Event

The event had to have had a long-term media presence that brought continuous attention to it or a notoriety among a communal, local or national community, to assume that an active choice was made in the aftermath of an event as to what should happen to the place.

A connection had to be made between place and event that implicated the place in the event or allowed it to take on some of the nature of the perpetrator. Places that become synonymous with negative imagery (prisons), or with victims or perpetrators.

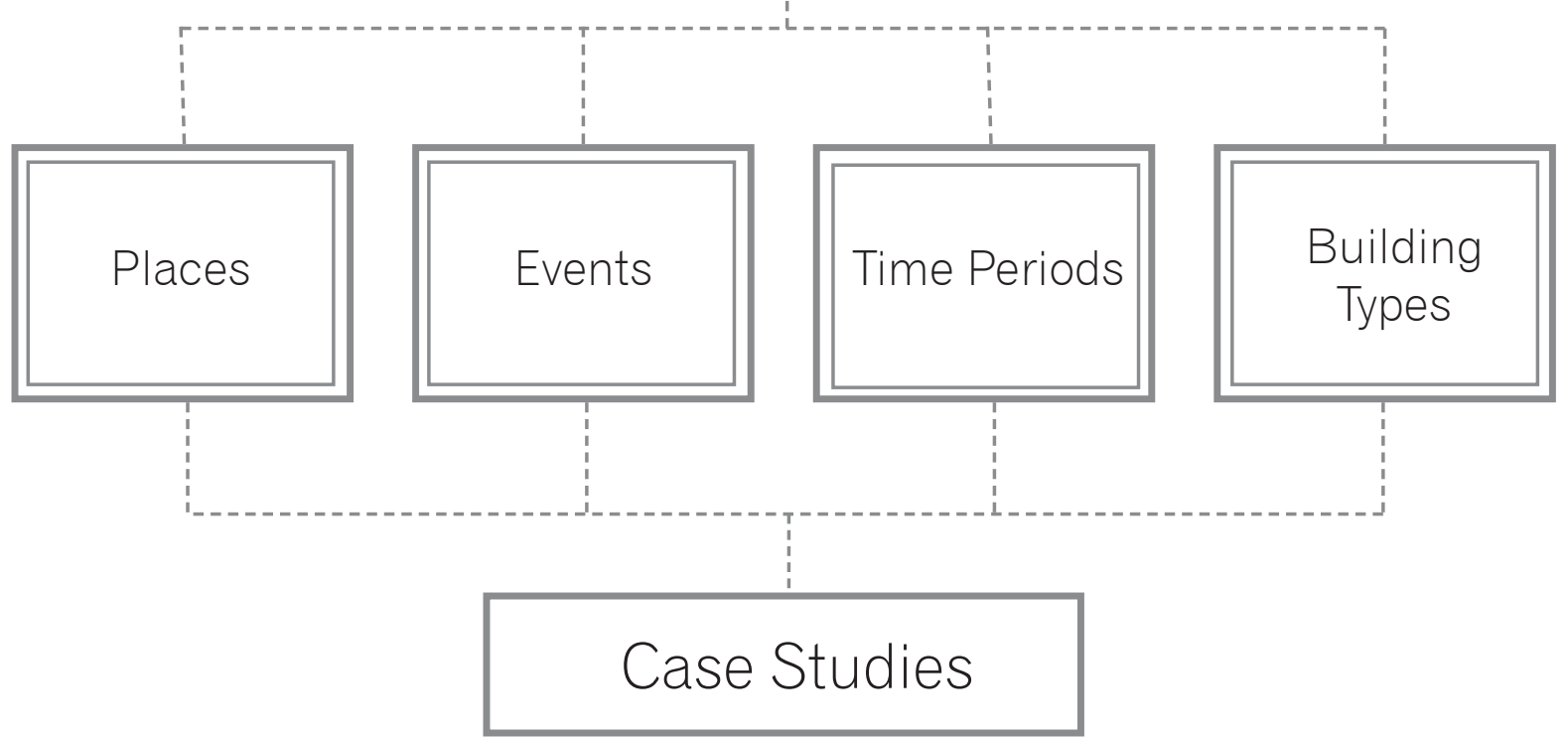




\section{Method for Categorising Sites}
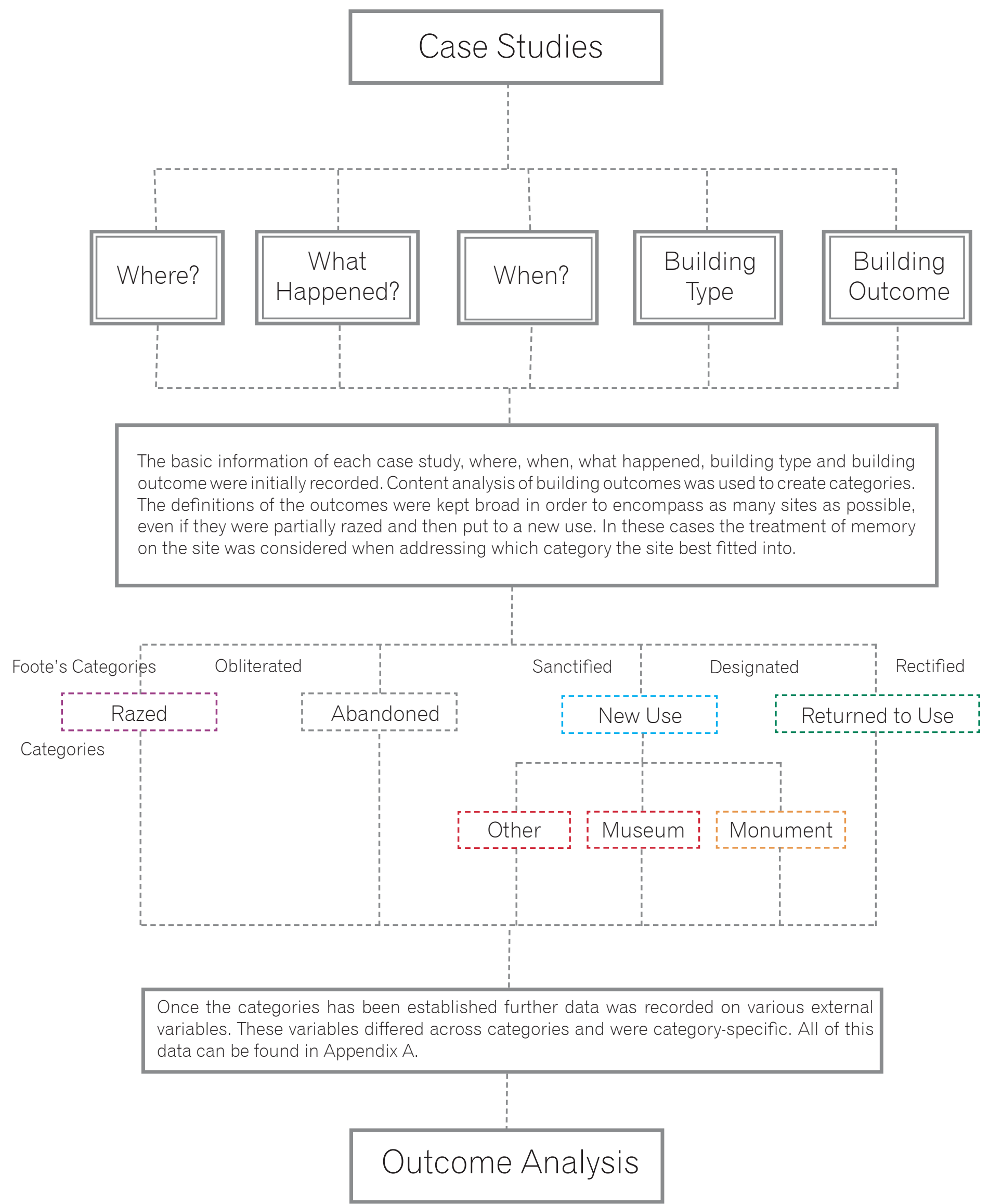


\section{Case Studies}

Summarized by Category Outcome in alphabetical order

\begin{tabular}{|c|c|c|c|c|c|c|}
\hline & Razed & Abandoned & Returned to Use & Other & Museum & Monument \\
\hline Abu Gharib, Iraq & & $x$ & & & & \\
\hline Addington Jail, NZ & & & & $x$ & & \\
\hline Alcatraz, USA & & & & & $x$ & \\
\hline Anlong Veng, Cambodia & & $x$ & & & & \\
\hline $\begin{array}{l}\text { Anne Frank House, Nether- } \\
\text { lands }\end{array}$ & & & & & $x$ & \\
\hline Auschwitz-Birkenau, Poland & & & & & & $x$ \\
\hline $\begin{array}{l}\text { Ayodha Mosque / Temple, } \\
\text { India }\end{array}$ & & $x$ & & & & \\
\hline The Bain House, NZ & $x$ & & & & & \\
\hline $\begin{array}{c}\text { Ballantynes Department } \\
\text { Store, NZ }\end{array}$ & & & $x$ & & & \\
\hline Bhopal Chemical Plant, India & & $x$ & & & & \\
\hline Broad Street Prison, Nigeria & $x$ & & & & & \\
\hline Buckeberg, Germany & & $x$ & & & & \\
\hline Buffalo State Asylum, USA & & & & $x$ & & \\
\hline Carandiru Penitentiary, Brazil & $x$ & & & & & \\
\hline Charles St. Jail, USA & & & & $x$ & & \\
\hline Choeung Ek, Cambodia & & & & & & $x$ \\
\hline Columbine High School, USA & & & $x$ & & & \\
\hline CTV Building, NZ & & & & & & $x$ \\
\hline David Grays Crib, NZ & $x$ & & & & & \\
\hline Dunblane Primary School, UK & $x$ & & & & & \\
\hline Dunedin Prison, NZ & & & & & $x$ & \\
\hline $\begin{array}{c}\text { Eastern State Penitentiary, } \\
\text { USA }\end{array}$ & & & & & $x$ & \\
\hline Emanuel AME, USA & & & $x$ & & & \\
\hline Featherston POW Camp, NZ & $x$ & & & & & \\
\hline Fritzl Basement, Austria & $x$ & & & & & \\
\hline Genbaku Dome, Japan & & & & & & $x$ \\
\hline Ground Zero, USA & & & & & & $x$ \\
\hline $\begin{array}{c}\text { Hampshire St. Horror House, } \\
\text { NZ }\end{array}$ & $x$ & & & & & \\
\hline Hoa Lo Prison, Vietnam & & & & & $x$ & \\
\hline House of Slaves, Senegal & & & & & $x$ & \\
\hline Invincible House, NZ & & & $x$ & & & \\
\hline Jonestown, Guyana & & $x$ & & & & \\
\hline $\begin{array}{c}\text { Katingal Special Security } \\
\text { Unit, Australia }\end{array}$ & $x$ & & & & & \\
\hline Kimberley Centre, NZ & & $x$ & & & & \\
\hline Lindt Cafe, Australia & & & $x$ & & & \\
\hline $\begin{array}{c}\text { Lizzie Borden Murder House, } \\
\text { USA }\end{array}$ & & & & $X$ & & \\
\hline
\end{tabular}




\begin{tabular}{|c|c|c|c|c|c|c|}
\hline & Razed & Abandoned & Returned to Use & Other & Museum & Monument \\
\hline London Underground, UK & & & $x$ & & & \\
\hline Long Island Railroad, USA & & & $x$ & & & \\
\hline Long Kesh / Maze Prison, UK & $x$ & & & & & \\
\hline Lorton Workhouse, USA & & & & $x$ & & \\
\hline Lundy Murder House, NZ & & & $x$ & & & \\
\hline $\begin{array}{c}\text { Manzanar Internment Camp, } \\
\text { USA }\end{array}$ & $x$ & & & & & \\
\hline Menendez Murder House, USA & & & $x$ & & & \\
\hline Mt. Carmel, Waco, USA & $x$ & & & & & \\
\hline Mt. Crawford, NZ & & $x$ & & & & \\
\hline Mt. Eden, NZ & & $x$ & & & & \\
\hline Napier Prison, NZ & & & & & $x$ & \\
\hline $\begin{array}{l}\text { Navy School of Mechanics } \\
\text { (ESMA), Argentina }\end{array}$ & & & & & $x$ & \\
\hline Oakley / Carrington Asylum, NZ & & & & $x$ & & \\
\hline $\begin{array}{c}\text { Oklahoma Federal Building, } \\
\text { USA }\end{array}$ & & & & & & $x$ \\
\hline Peter Tobin House, UK & & & $x$ & & & \\
\hline Porirua Mental Asylum, NZ & & & & & $x$ & \\
\hline Port Arthur, Australia & & & & & $x$ & \\
\hline Presidio Modelo, Cuba & & & & & $x$ & \\
\hline Pripyat, Ukraine & & $x$ & & & & \\
\hline Robben Island, South Africa & & & & & $x$ & \\
\hline $\begin{array}{c}\text { Sandy Hook Elementary School, } \\
\text { USA }\end{array}$ & $x$ & & & & & \\
\hline Seacliff Mental Asylum, NZ & $x$ & & & & & \\
\hline Simpson Murder House, USA & & & $x$ & & & \\
\hline Sixth Floor Museum, USA & & & & & $x$ & \\
\hline Spandau Prison, Germany & $x$ & & & & & \\
\hline Staro Sajmiste, Serbia & & & & $x$ & & \\
\hline Sultanahmet Prison, Turkey & & & & $x$ & & \\
\hline $\begin{array}{c}\text { Terezin Memorial, Czech } \\
\text { Republic }\end{array}$ & & & & & $x$ & \\
\hline Tuol Sleng, Cambodia & & & & & $x$ & \\
\hline Utoya Island, Norway & & & $x$ & & & \\
\hline Wellington Fever Hospital, NZ & & & & $x$ & & \\
\hline Wellington Trades Hall, NZ & & & & $x$ & & \\
\hline West Murder House, UK & $x$ & & & & & \\
\hline White House Farm, UK & & & $x$ & & & \\
\hline Willard Asylum, USA & & $x$ & & & & \\
\hline
\end{tabular}

Table 1: 70 Case Studies in their corresponding categories. Case Study data can be found in Appendix A 



\section{Analysis: Outcomes}

This section describes each of the four categories (razed, abandoned, returned to use and new use). These descriptions provide a definition of the category as part of this thesis, a list of the categorised sites and an overview of the analysis discussing some of the main patterns and irregularities found in the data as well as timing diagrams and a look at the different phases and relationships the sites have had with the memories of the event.

\section{Razed}

The definition of this category is drawn from Foote's strategy of obliteration where the building or site has been demolished or scoured of traces of the difficult history and also where the building has been partially demolished to the point where it is unrecognisable as the original place, or can no longer be reused for its original purpose. Prior to World War II, demolition was the most common method of dealing with, not only difficult heritage, but any building of which had outstripped its use. However, post-World War II, as buildings began to be recognised as part of a heritage that ought to be preserved, demolition became less straight forward and the saving and memorialising of place became a priority. All of the buildings examined in this category were razed, post-WWII and were analysed in order to understand what factors must be present for a building to be demolished in the age of heritage, memory and identity.

\begin{tabular}{|c|c|c|c|c|}
\hline & Building Use & Place & Event & Razed \\
\hline Broad Street Prison & Prison & Nigeria & $1885-1976$ & 1976 \\
\hline Seacliff Mental Asylum & Mental Asylum & New Zealand & $1887-1973 / 1942$ & 1973 \\
\hline Spandau Prison & Prison & Germany & $1897-1987$ & 1987 \\
\hline Manzanar Internment Camp & Internment Camp & United States of America & $1941-1945$ & 1945 \\
\hline Featherston POW Camp & Internment Camp & New Zealand & 1943 & 1945 \\
\hline Carandiru Penitentiary & Prison & Brazil & 1956 - 2002 / 1992 & 2002 \\
\hline Long Kesh/Maze Prison & Prison & United Kingdom & 1971 - 2000 / 1981 & 2006 \\
\hline West Murder House & House & United Kingdom & $1975-1994$ & 1996 \\
\hline Katingal Special Security Unit & Prison & Australia & $1975-1978$ & 2006 \\
\hline Fritzl House & House & Austria & $1984-2008$ & 2013 \\
\hline David Grays Crib & House & New Zealand & 1990 & 1990 \\
\hline Mt. Carmel, Waco & Residential Compound & United States of America & 1993 & 1993 \\
\hline The Bain House & House & New Zealand & 1994 & 1994 \\
\hline Dunblane Primary School & Primary School & United Kingdom & 1996 & 1996 \\
\hline Hampshire St. Horror House & House & New Zealand & 2009 & 2009 \\
\hline Sandy Hook Elementary School & Primary School & United States of America & 2012 & 2013 \\
\hline
\end{tabular}

Table 2: Sites that have been razed or made unrecognisable, listed in the order that they were razed 
The research shows that there are a range of reasons why a site might be razed. It may have outlived its use, it may not be structurally safe, or it may have witnessed a tragic or cruel event and house dark memories. My analysis shows that the why and how of a building being demolished is dependent on the building type. 16 of my case studies (23\%) have been either completely or partially demolished. These buildings are now no longer able to fulfil their initial use.

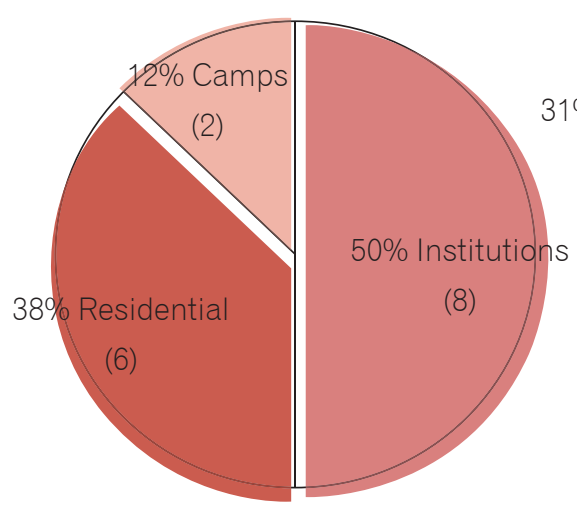

Building Type

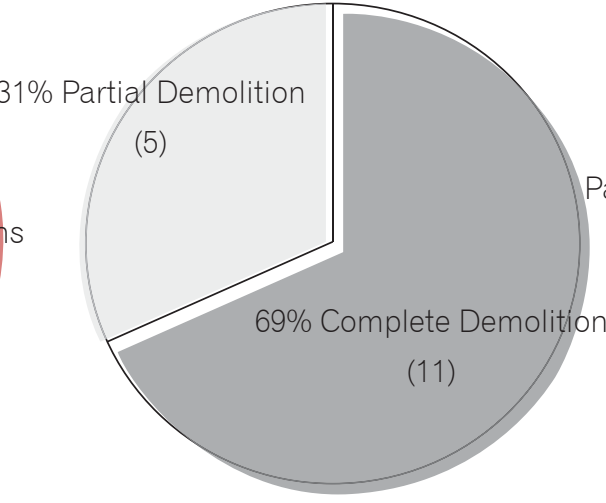

Outcome

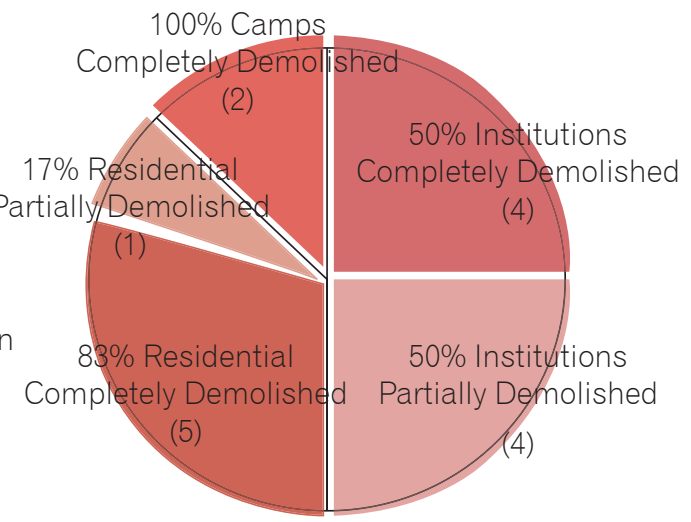

Building Type by Outcome

Of those partially demolished, all were large institutions with costly demolitions. Carandiru Penitentiary has turned its remaining representative building into a prison museum and Long Kesh/Maze is likely to do the same in the coming years. The Fritzl House is different because it was destroyed through concretization rather than demolition, though unable to be used for its initial use, architecturally the creation of a completely solid mass has very different connotations to that of a void. These solid masses also have the ability to be used as memorials to the use and occupation of space such as in Rachel Whitereads 'Room 101' and 'House', casts of negative space with intimate relationships to how space is occupied.

How demolition is sanctioned is also important to this study. If the demolition of the building is statesanctioned it generally reflects a national embarrassment or a shame that is so widespread that it demands official attention. If a building is illegally destroyed by a member of the surrounding community then again we can assume that a sense of shame or hatred surround the building and that eradication of the structure is a symbolic gesture, to eradicating the memory of a tragic or cruel event from a community

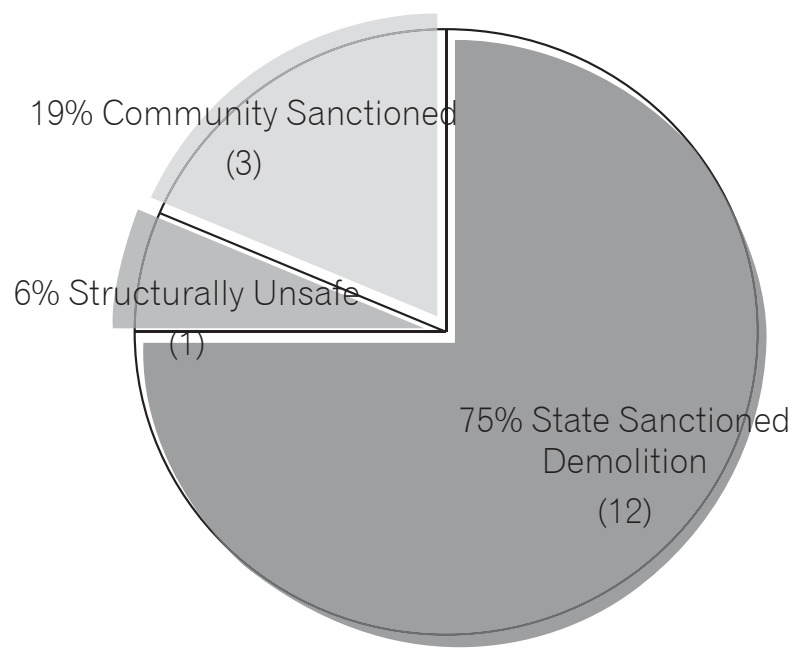

Demolition Process

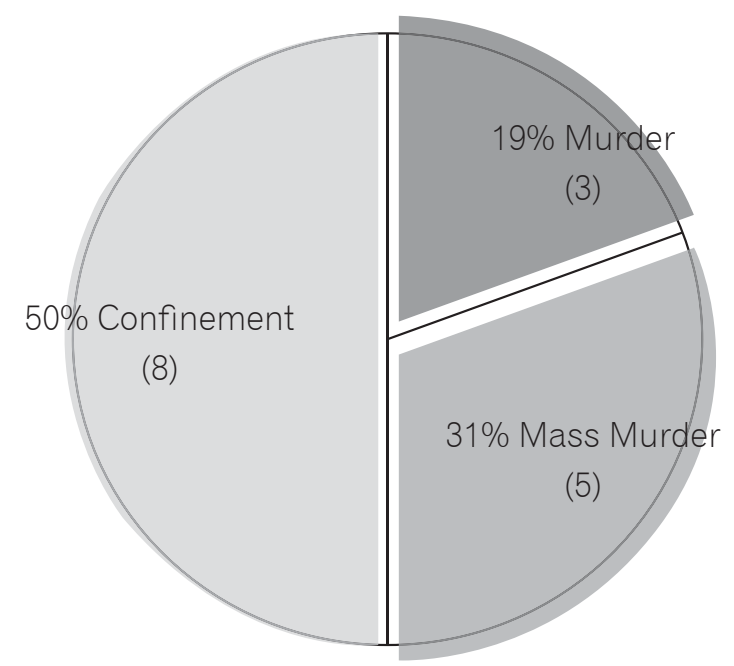

Nature of Event

In my analysis sites that were completely razed, tended to have witnessed high impact events, which affected a wide group of people, and gained instant notoriety. These sites were destroyed fairly quickly. If a site was destroyed following a negative event it occurred almost instantly, no matter who controlled the process. It appears that the more time that passed, while decisions were made about the future of a site, the more likely the site was to be saved. In contrast, buildings which were the site of high profile traumatic events, appear to have been deemed a potential threat to the balance of public life. It appears that the fear of these abandoned structures becoming shrines or monuments, meant that these buildings were quickly demolished to prevent this. Thus time appears to have been a critical factor in the fate of a place. 

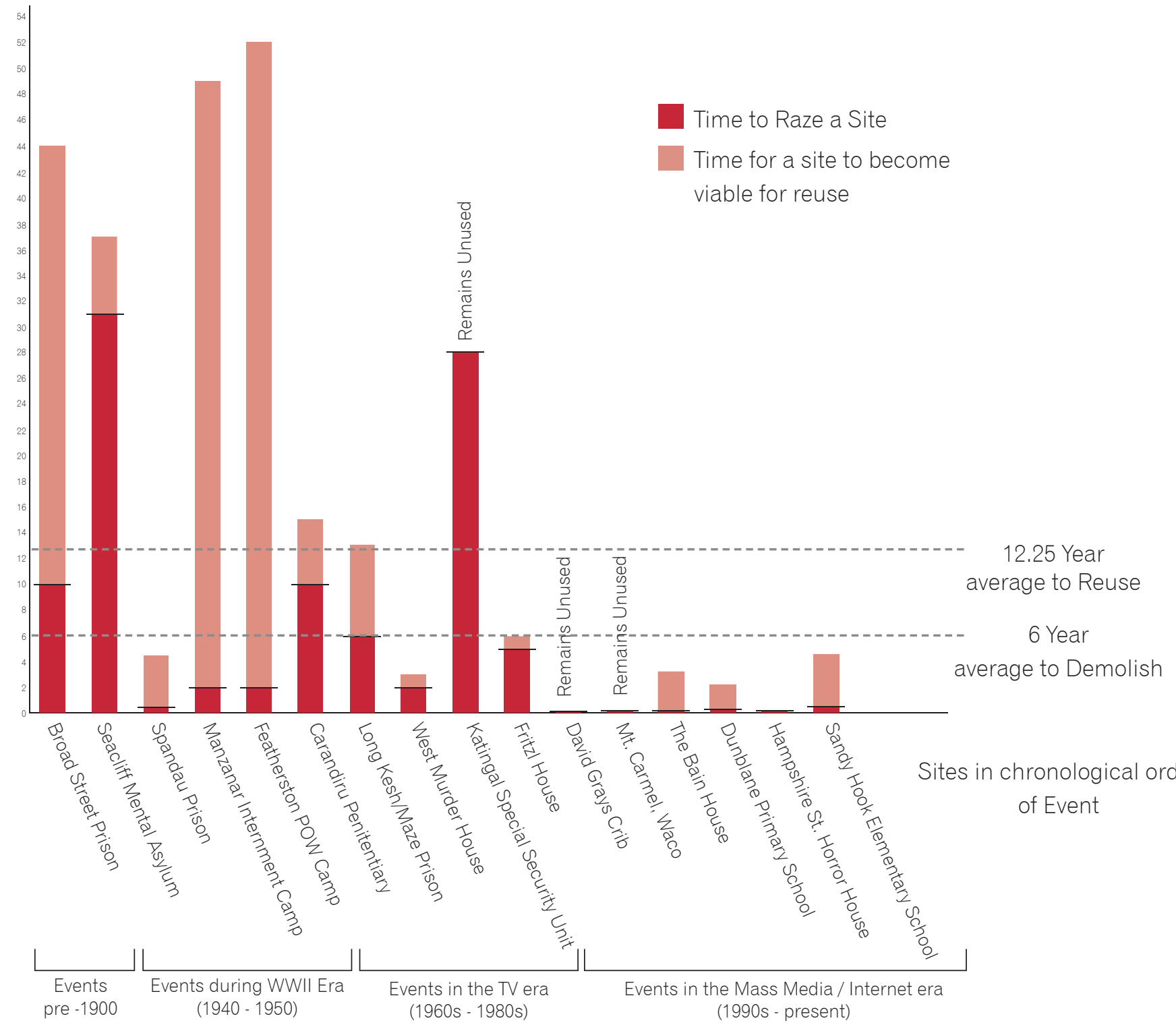

Timing to Raze Sites

Interestingly, as shown in the graph above, it would appear that the time it takes to destroy a site has become smaller, with the reaction time under two years for all cases in the era of mass media. The influence of mass media brings these events into people's living rooms, increasing the 'geographical specificity' of death and suffering and making reactions to events more visceral and immediate ${ }^{3}$. The average time it took to raze site in this category is 6 years. Shown in pink on the graph is the time it takes for a site to be reused. Many sites appear to have been deemed to be more valuable without their buildings (See, The Bain House p121 and Buffalo State Asylum p126) and therefore it appears that the buildings were demolished to make way for a quick sale. After some time, many of the sites have been reconstructed, or have had memorials placed on the site. Many of the sites have been developed into public space, parks or walkways; signals of the past that are open to public interpretation in the present. The average time it takes for a site to be reused after demolition is 12.25 years; double that it takes for demolition. It is also worth noting that there are many places that are yet to be reused in 2017 and may be reused in the future.

It's worth noting that voids or gaps that are caused by the demolition of these places still represent the event. Difficult memory has a parasitic relationship with any physical remnants still triggering reactions in the collective memory. For example, the new residents of 65 Every Street, the Bain House, say that people still creep onto the property looking for souvenirs. Long Kesh/Maze sits unable to be developed because its void is a symbol of the struggles that Northern Ireland is still to overcome, while the residents of Sandy Hook chose to rebuild the school on the same site to cover up the memory of everything a shooting rampage took away from ${ }^{4}$. The awareness that demolition is not always an effective method of erasure has stopped many authorities from demolishing in recent years and may be the reason why there are not many heavily urban or commercial sites in this category ${ }^{5}$. 

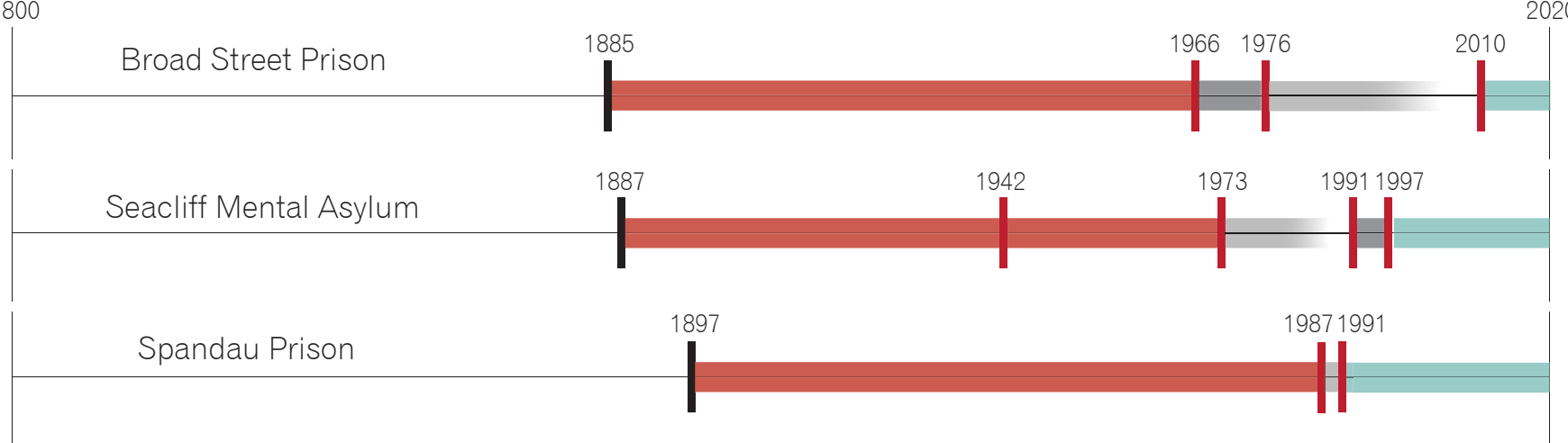

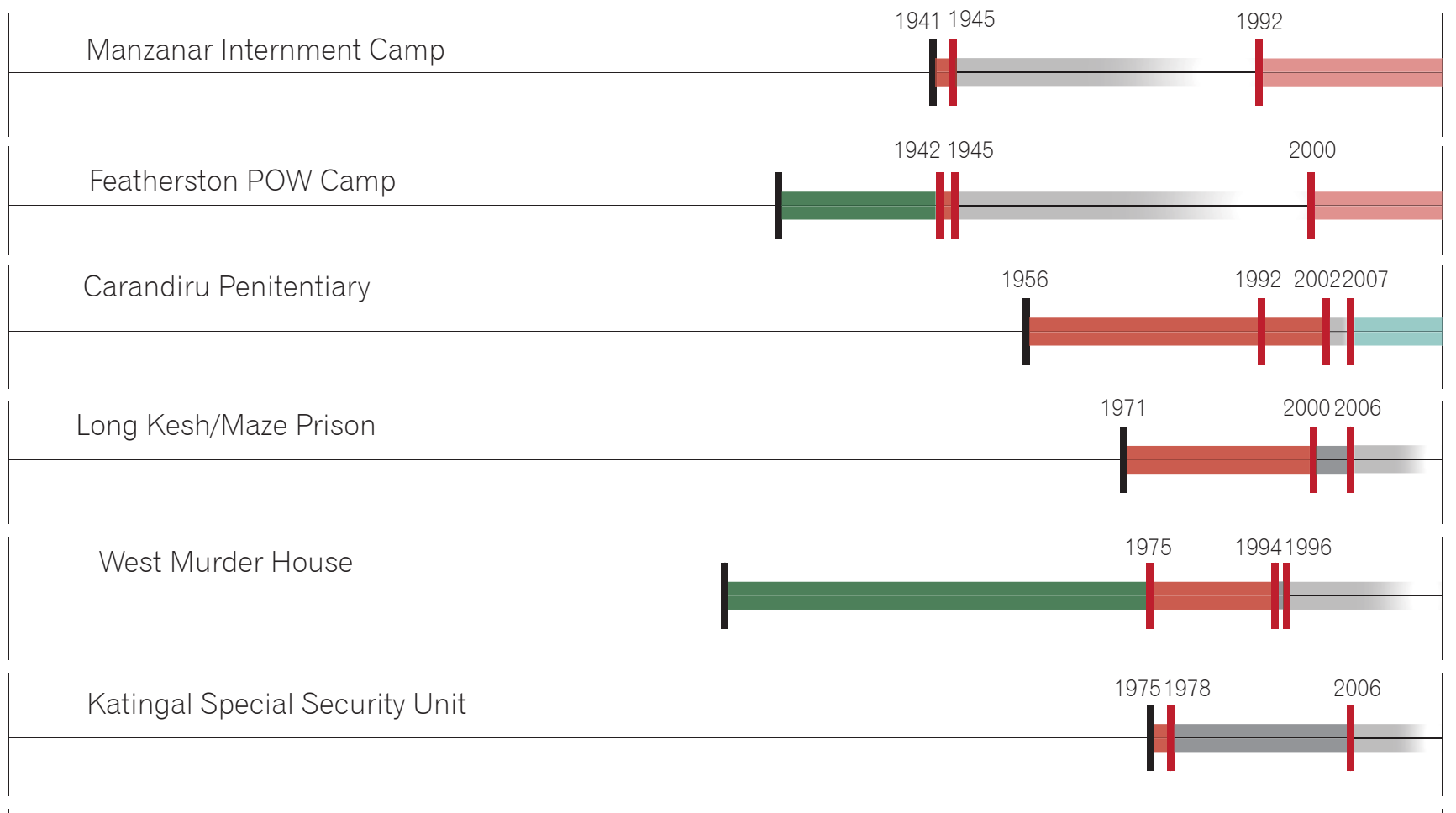

Fritzl House

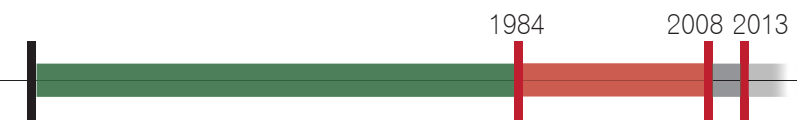

David Grays Crib

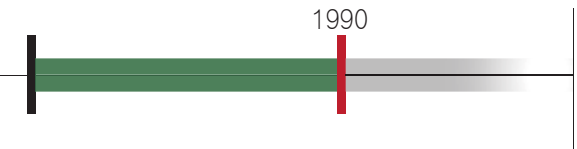

Mt. Carmel, Waco

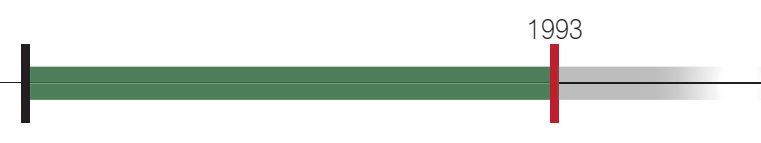

The Bain House

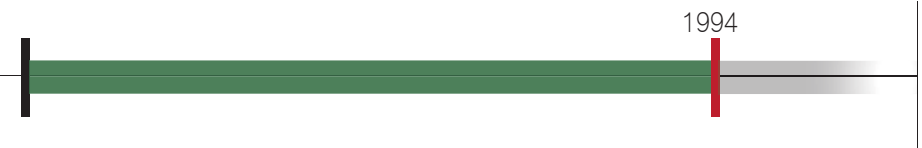

Dunblane Primary School

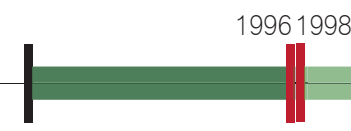

Hampshire St. Horror House

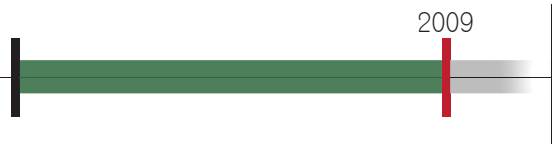

Sandy Hook Elementary School

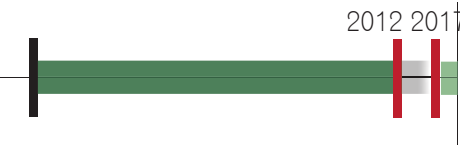

- n 'Negative' Use 


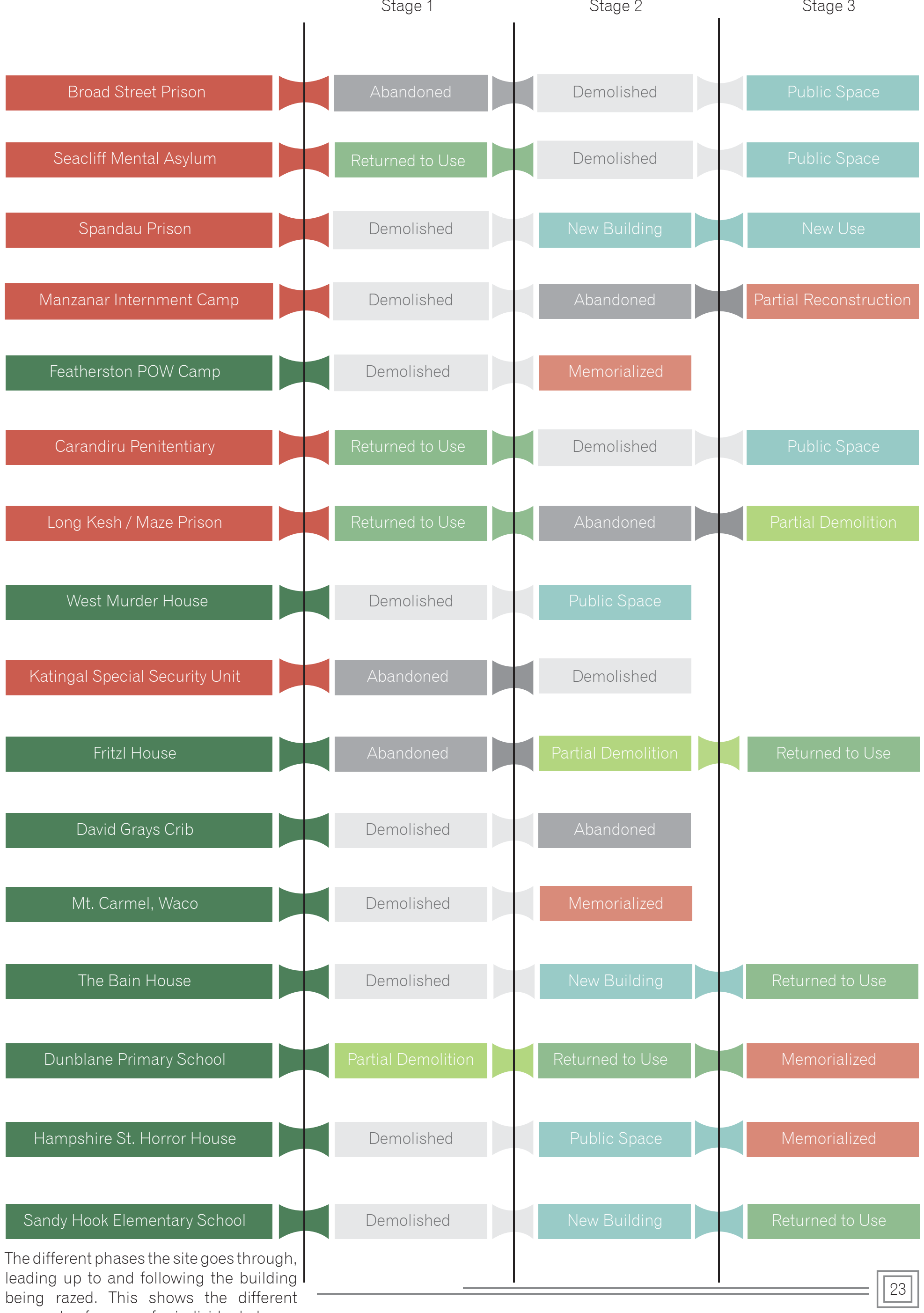
being razed. This shows the different moments of erasure for individual places. 



\section{Abandoned}

In this category the site is no longer being used for its original purpose and has yet to be destroyed or converted to a new use. Abandoned buildings live in an in-between stage often while governments and communities figure out how to deal with and react to them. Some sites are too hard or too expensive to demolish, others are too controversial to develop, a mixture of both is fairly common. An alternative is that the sites are physically unsafe to live on or enter. Importantly the sites in this category were abandoned in 2017 but are unlikely to remain that way forever, almost all of my case studies were abandoned at one point or another but were later developed or demolished.

\begin{tabular}{|c|c|c|c|c|}
\hline & Building Use & Place & Event & Abandoned \\
\hline Willard Asylum & Mental Asylum & United States of America & $1869-1995$ & 1995 \\
\hline Mt. Eden Prison & Prison & New Zealand & $1885-2011$ & 2011 \\
\hline Mt. Crawford Prison & Prison & New Zealand & $1927-2012$ & 2012 \\
\hline Buckeberg & Festival Grounds & Germany & $1933-1937$ & 1937 \\
\hline Kimberley Centre & Mental Deficiency Hospital & New Zealand & $1945-2006$ & 2006 \\
\hline Abu Gharib & Prison & Iraq & $1959-2014$ & 2014 \\
\hline Anlong Veng & Houses & Cambodia & $1975-1998$ & 1998 \\
\hline Jonestown & Residential Compound & Guyana & 1978 & 1978 \\
\hline Bhopal Chemical Plant & Industrial Complex & India & 1984 & 1986 \\
\hline Pripyat & Town & Ukraine & 1986 & 1986 \\
\hline Ayodhya Mosque / Temple & Religious Building & India & 1992 & 1992 \\
\hline
\end{tabular}

Table 3: Sites that have been abandoned, listed in the order that they were abandoned 
Buildings or sites are abandoned because they are unsafe, unneeded or disputed. Many sites studied here remain abandoned because of their remote locations, with no local interest group committed to their survival or destruction. Just as many sites are still being fought over, their memories too potent to allow for their development at this stage. While some may continue to be abandoned, at any time they could be saved as heritage, or demolished as shameful or a nuisance. This appears to be dependent on the economic viability of the site, cultural or social acceptance or the fading of collective memory.

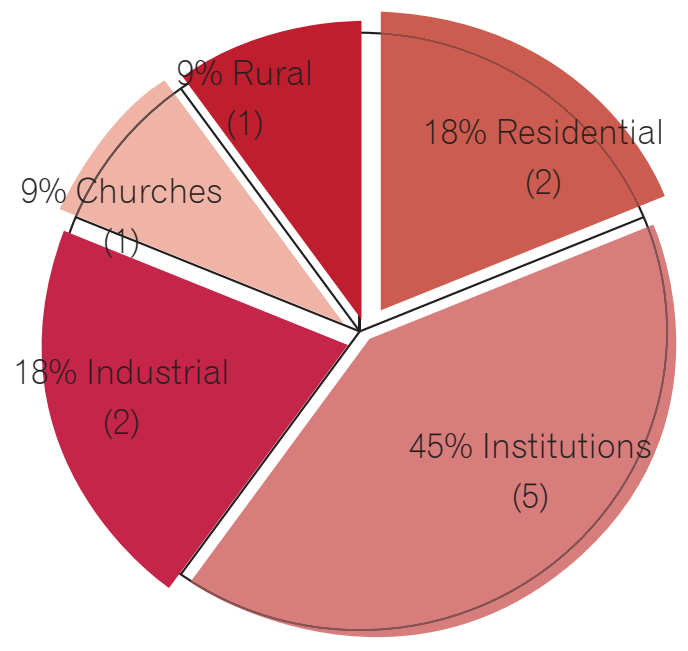

Building Type

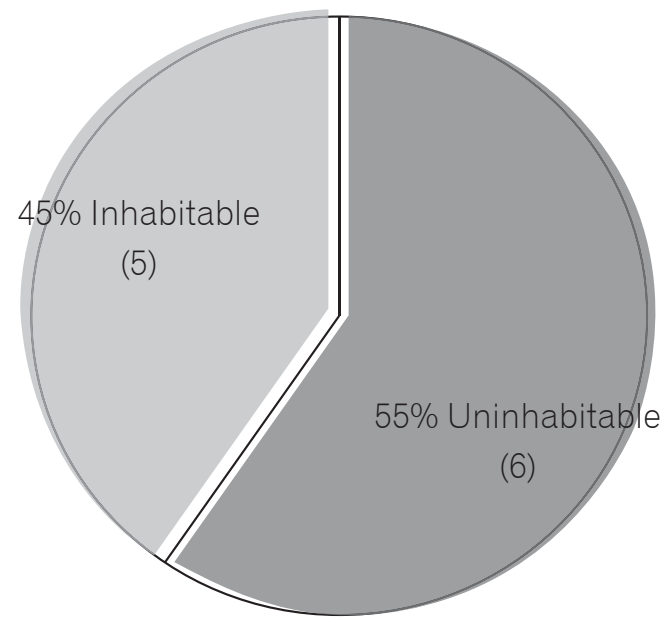

Inhabitable

The data suggests that the longer a site is left abandoned the more likely it is to stay that way, making timing important to the future development of the site. As can be seen below the sites that have been abandoned the longest are the most heavily disputed and therefore the least viable for redevelopment. Five sites were deemed viable by their local interest groups in 2017, as determined by economic and design feasibility studies carried out by owners and local authorities. Willard and Mt. Eden are both likely to be saved because of their urban and character aspects providing higher economic return if redeveloped. Anlong Veng is already being developed by

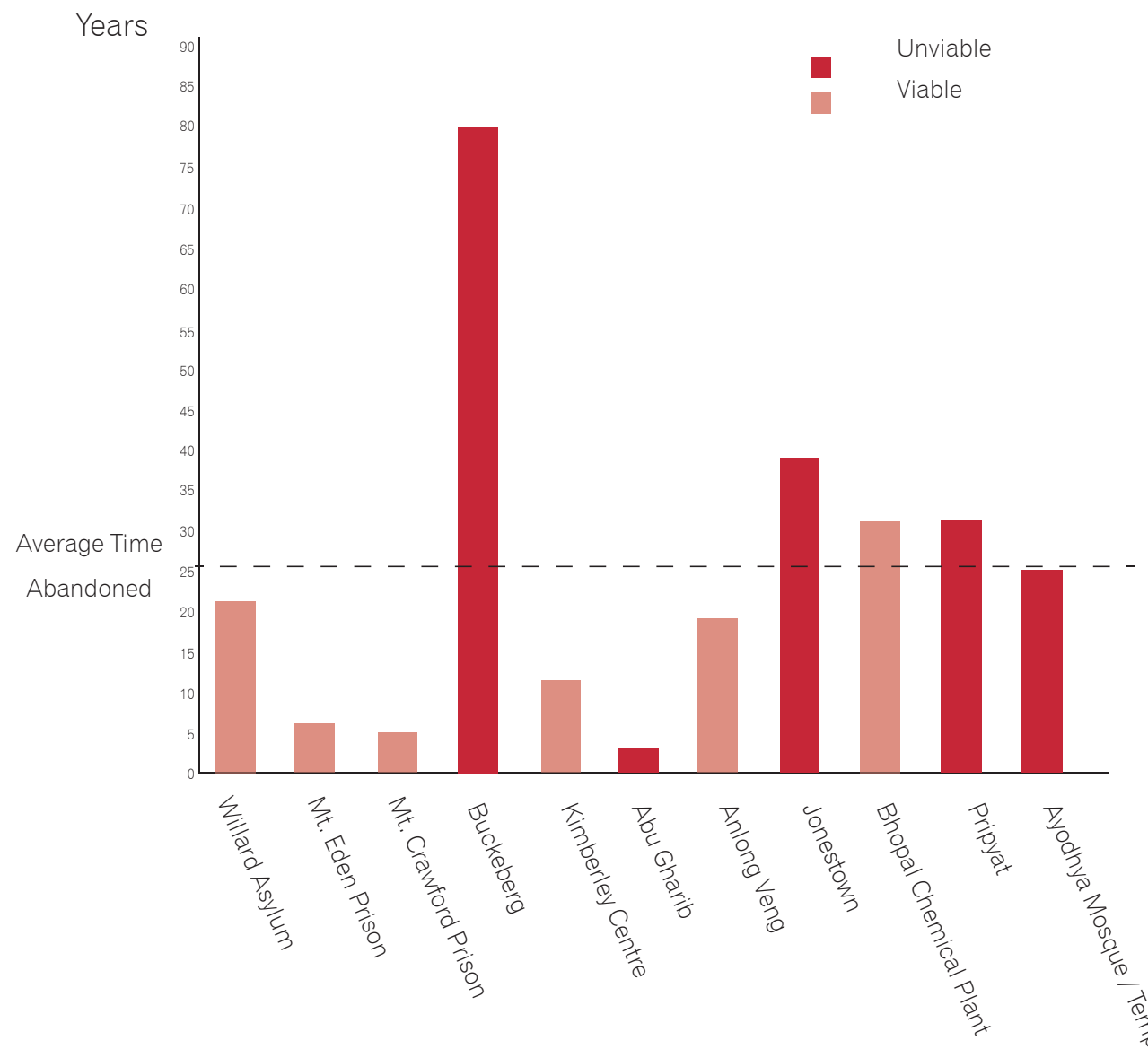
the Federal Government as a tourist destination ${ }^{6}$. Mt. Crawford is also under feasibility study but its location and lack of aesthetic character may mean the site is razed and then developed ${ }^{7}$. Bhopal has had many memorials designed for the site and has often been considered for public access, but plans go unfulfilled because of financial concerns and a public that is still suffering from the effects of the tragedy. Of the five sites that are currently deemed unviable by their local interest groups it is unlikely that any are to become viable in the near future because they are either disputed or unsafe. Of those sites that are currently uninhabited due to safety, Pripyat, a site of nuclear fallout is unlikely to be fully inhabited again due to fear of radiation poisoning despite hundreds of people moving back into the Chernobyl fallout zone in the last decade9. Jonestown, neglected for the last 40 years, has been retaken by the jungle without a local interest group to preserve the site. 


\begin{tabular}{|l|} 
Willard Asylum \\
\hline
\end{tabular}

Mt. Eden Prison

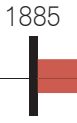

2011

Mit. Eden Prison

Mt. Crawford Prison

1927

2012

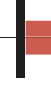

Buckeberg

19331937

(1)

Kimberley Centre

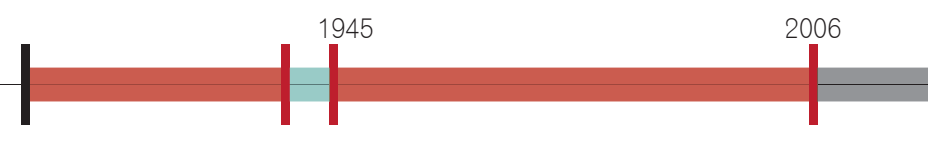

Abu Gharib

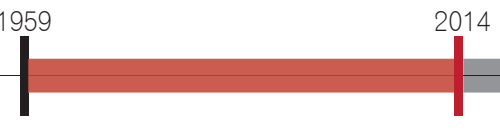

Anlong Veng

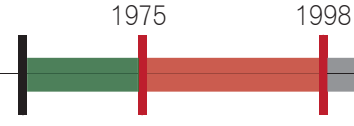

Jonestown

1978

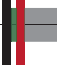

Bhopal Chemical Plant

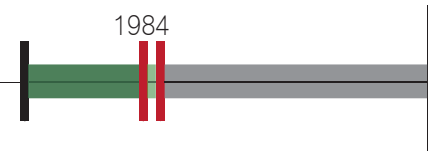

Pripyat

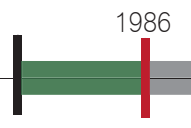

Ayodhya Mosque / Temple

1992

Key 


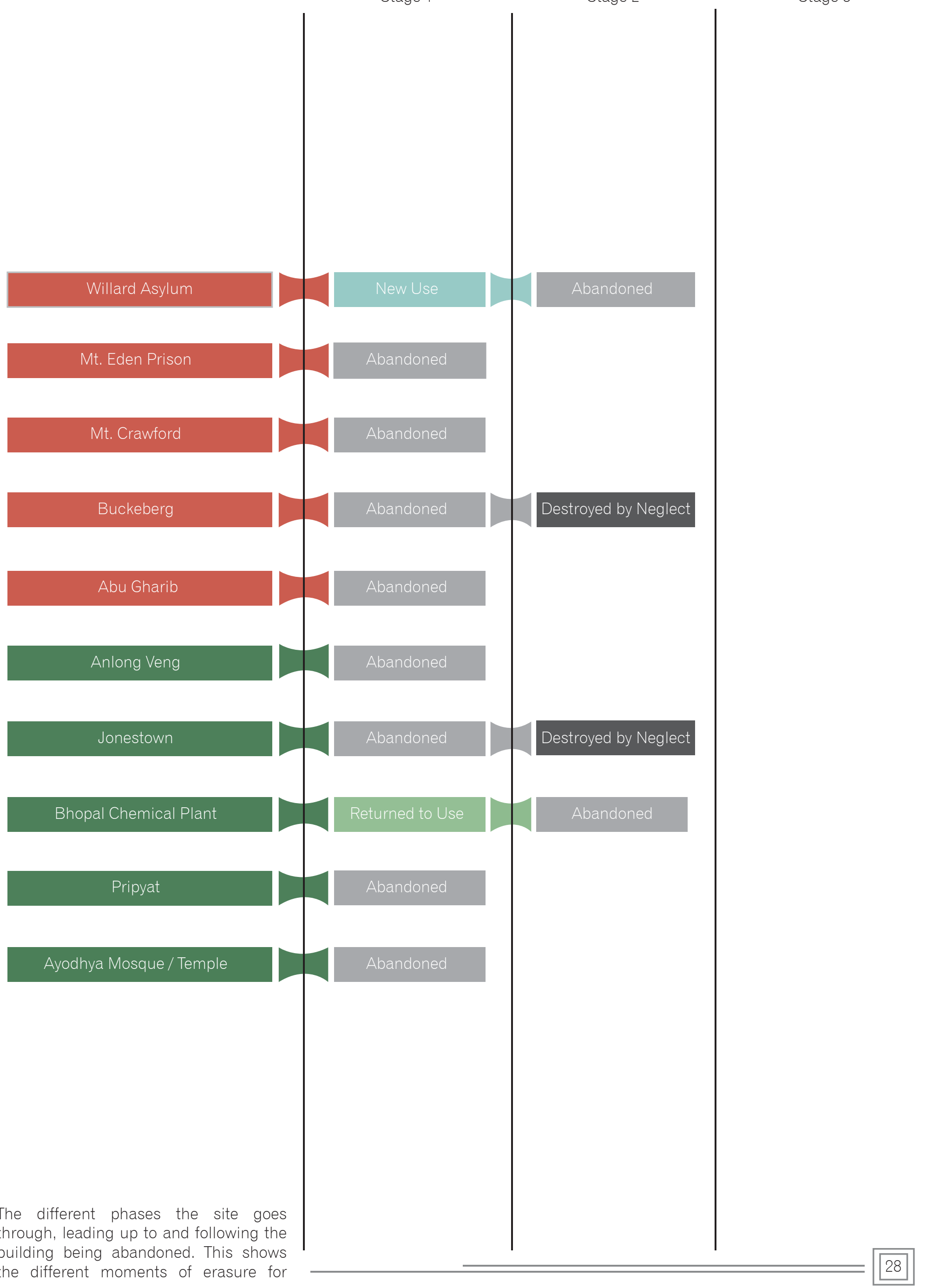




\section{Returned to Use}

Places of negative heritage are able to be returned to use when the original purpose is able to co-exist with knowledge of the difficult event. In these cases generally all the evidence of the difficult history has been erased from the place which is then returned back to its original use. Some sites are returned to use in the immediate aftermath of an event, but are later deemed meaningful and developed into a new use that marks the event such as the town of Terezin in the Czech Republic or the Sixth Floor Museum in Dallas Texas. Those places have not been included in this section, but in the new use section in their later developed states as museums or memorials. The sites included here are sites that were able to be 'othered' to the point where the re-occupation of the space has allowed the memory to fade and the place is are no longer associated directly with the memory of the event.

\begin{tabular}{c|c|c|c|c} 
& Building Use & Place & Event & Returned to Use \\
\hline Ballantynes Department Store & Retail Store & New Zealand & 1947 & 1947 \\
\hline Wellington Trades Hall & Office Building & New Zealand & 1984 & 1984 \\
\hline White House Farm & House & United Kingdom & 1989 & 1986 \\
\hline Menendez Murder House & House & United States of America & 1991 & 1994 \\
\hline Tobin Murder House & House & United Kingdom & 1994 & 1995 \\
\hline Long Island Railroad & Transportation & United States of America & 1994 \\
\hline Invincible House & Office Building & New Zealand & 1994 \\
\hline Simpson Murder House & House & United States of America & 1999 & 1997 \\
\hline Lundy Murder House & High School & United States of America & 2000 \\
\hline London Underground & Transportation & United Kingdom & 2005 & 2002 \\
\hline Utoya Island & Island Camp & Norway & 2011 & 2005 \\
\hline Lindt Cafe & Cafe & Australia & 2014 & 2016 \\
\hline Emanuel AME Church & Church & United States of America & 2015 & 2015
\end{tabular}

Table 4: Sites that have been returned to use, listed in the order of the year they were returned to use 
Places that were returned to use, appear to have been done so as an efficient use of money and time. Commercial buildings, the greatest proportion of sites in this category, are less personal than residential sites and issues of economic/financial return are more pressing. The research suggests that there can be a psychological toll taken in the violation of sacred space, such as the home, that does not occur in an office tower or retail store that we merely pass through. It appears these buildings were more easily re-occupied with minimal changes (usually surrounding safety), or occupied by entirely new people, with no change to the building envelope, allowing an event to fade from the collective memory through re-occupation of the site. Residential dwellings that witnessed low impact events were also re-occupied with very little change to the building envelope when occupation was by completely new occupants and kept largely away from media attention. For example, since the production of the true crime dramas about the Menendez and Simpson murders (2016), both of the former residences in California, which have had new owners for the last 20 years, and were returned to use out of the public eye, have become attractions for 'entertainment' tourists and members of the media as the stories once again became high profile.

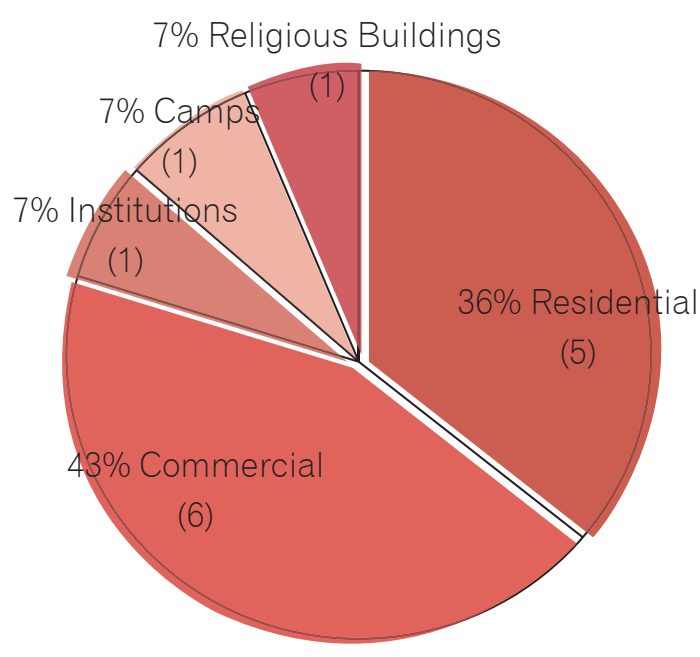

Building Type

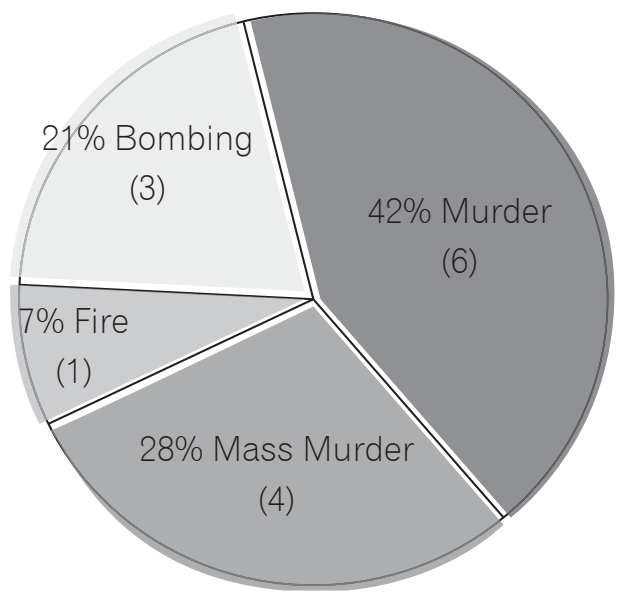

Nature of Event

As shown below, the data showed an average time of 2.2 years to return a building to use. The amount of time appears to have been dependent on the degree of intervention needed in order to once again make people feel safe in their environment and appear to depend on the level of symbolism the place embodied of the events, victims or perpetrators.

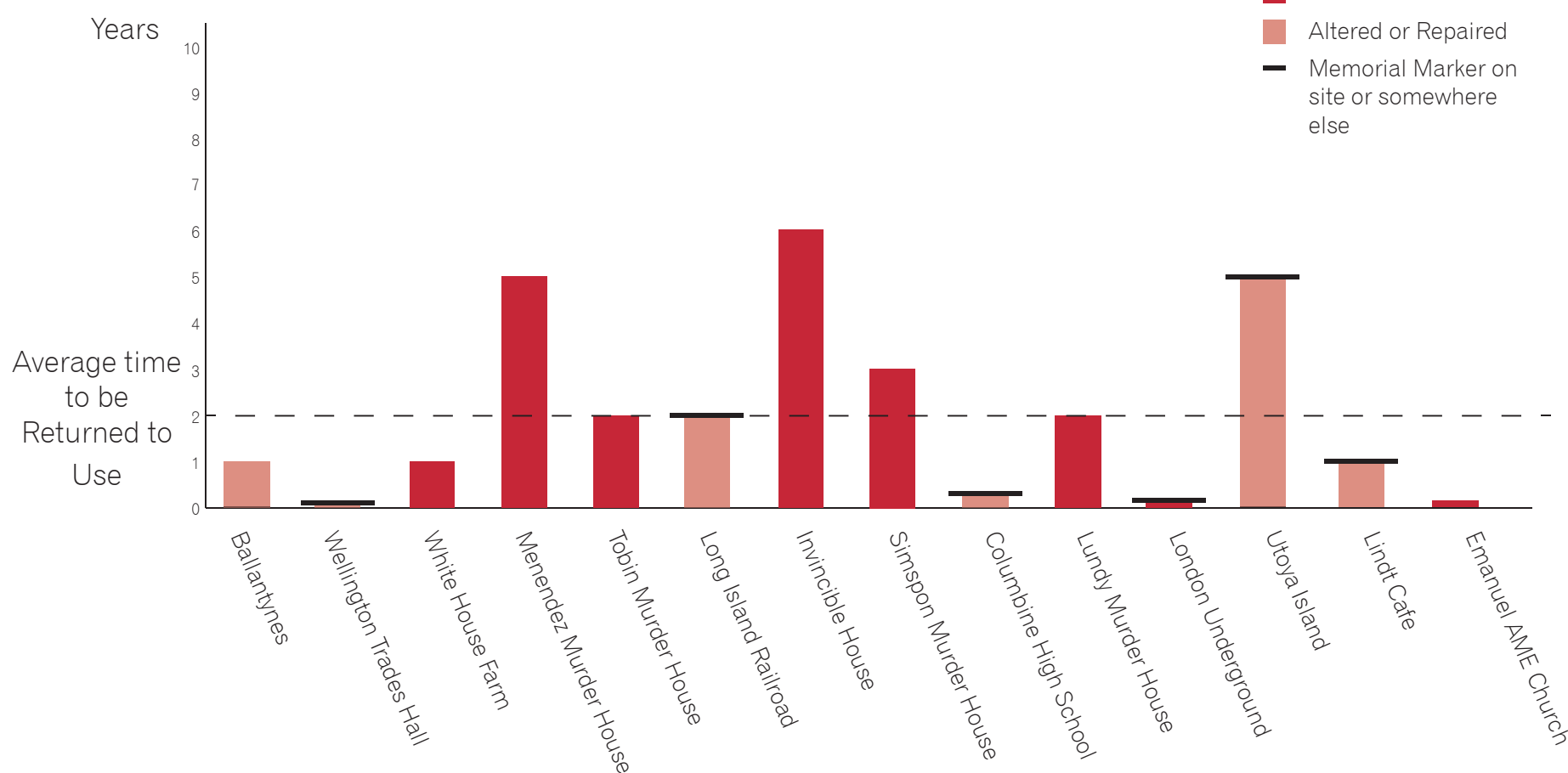

In the case of, most notably, Utoya Island, but also others (Emanuel AME Church, London Underground etc.), the places were returned to use as a symbolic gesture of resilience and defiance ${ }^{10}$. In these cases, the events can be identified as acts of terrorism or racism and the reoccupation of the site by the persecuted community is a symbol of survival, and a statement that the event has not changed the day to day activities of that community, despite the threats and intimidation. 

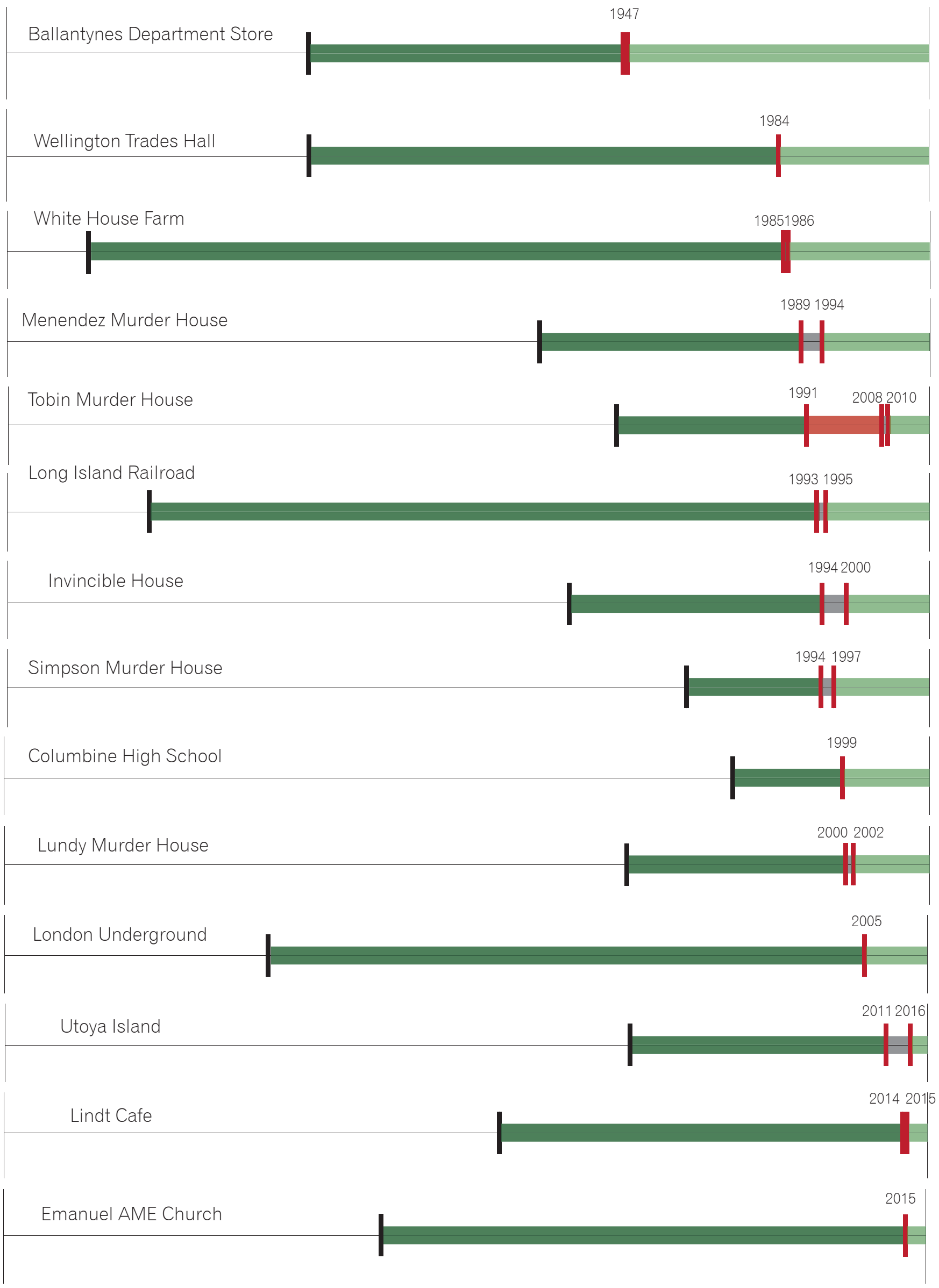

Key 

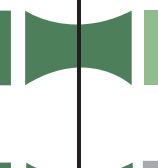

Returned to Use

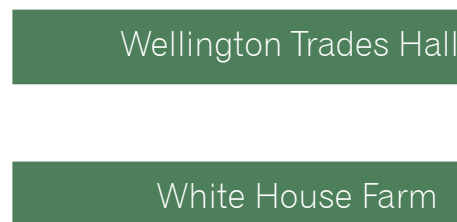

Menenedez Murder House

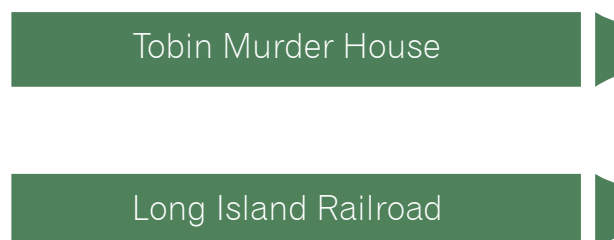

Invincible House

Simpson Murder House

Columbine High School
Abandoned
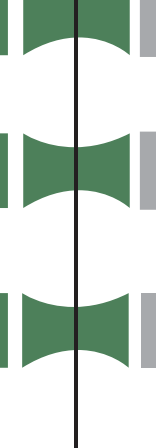

Abandoned

Abandoned

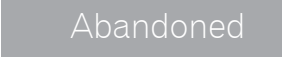

Abandoned

Abandoned
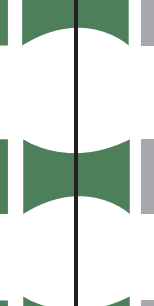

Abandoned

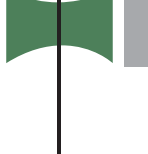

Abandoned

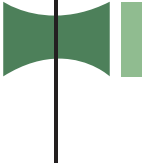

Returned to Use
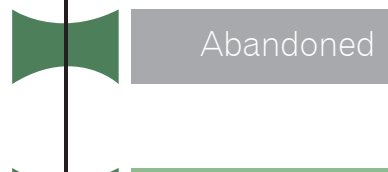

\section{London Underground}

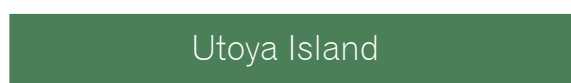

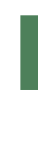

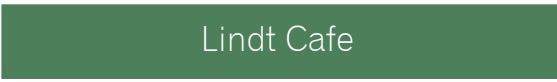

Emanuel AME Church

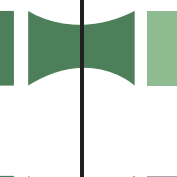

Returned to Use

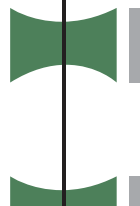

Abandoned

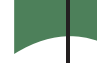

Abandoned
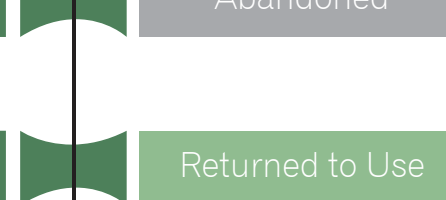

Returned to Use

Returned to Use

Returned to Use

Returned to Use

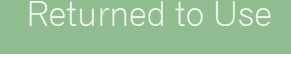

Returned to Use

Memorializeo

Returned to Use

Memorialized

Memorialized

Returned to Use
The different phases the site goes through, leading up to and following the building being returned to use. 


\section{New Use}

New Use is where the building or site has been adaptively reused for another purpose. This purpose may be as a museum to the places negative history, a marketed tourist attraction. It may be as a monument, where a memorial to the victims of the event is the main purpose of the place and no other active process has taken place. Or it may be another new use, independent of its negative history when either that history has been erased and the place makes no reference to it, or the site uses the event as an indicator of place and presents a contemporary narrative that situates and gives a positive profile to the new use.

\begin{tabular}{|c|c|c|c|c|}
\hline & Building Use & Place & Event & Reused \\
\hline House of Slaves & House & Senegal & $1776-1810$ & 1978 \\
\hline Robben Island & Prison & South Africa & $1781-1996$ & 1999 \\
\hline Eastern State Penitentiary & Prison & United States of America & $1829-1970$ & 1994 \\
\hline Port Arthur & Prison & Australia & $1833-1877 / 1996$ & 1979 \\
\hline Charles St. Jail & Prison & United States of America & $1851-1990$ & 2007 \\
\hline Napier Prison & Prison & New Zealand & $1862-1993$ & 2002 \\
\hline Oakley / Carrington Asylum & Mental Asylum & New Zealand & $1865-1992$ & 1992 \\
\hline Addington Jail & Prison & New Zealand & $1874-1999$ & 2006 \\
\hline Buffalo State Asylum & Mental Asylum & United States of America & $1880-1976$ & 2017 \\
\hline Porirua Mental Asylum & Mental Asylum & New Zealand & $1887-1977$ & 1987 \\
\hline Hoa Lo Prison & Prison & Vietnam & $1889-1985$ & 1995 \\
\hline Lizzie Borden House & House & United States of America & 1892 & 1996 \\
\hline Dunedin Prison & Prison & New Zealand & $1896-2007$ & 2017 \\
\hline Lorton Workhouse & Prison & United States of America & $1910-2001$ & 2008 \\
\hline Sultanahmet Prison & Prison & Turkey & $1919-1969$ & 1996 \\
\hline Wellington Fever Hospital & Fever Hospital & New Zealand & $1919-1981$ & 2013 \\
\hline Presidio Modelo & Prison & Cuba & $1928-1967$ & 1978 \\
\hline Alcatraz & Prison & United States of America & 19341968 & 1972 \\
\hline Terezin Memorial & Town & Czech Republic & $1940-1945$ & 2002 \\
\hline Anne Frank House & House & Netherlands & $1940-1944$ & 1960 \\
\hline Staro Sajmiste & Concentration Camp & Serbia & $1941-1944$ & 1955 \\
\hline Auschwitz - Birkenau & Concentration Camp & Poland & $1941-1945$ & 1947 \\
\hline Genbaku Dome & Museum & Japan & 1945 & 1950 \\
\hline Sixth Floor Museum & Office Building & United States of America & 1963 & 1989 \\
\hline Choeung Ek & Orchard & Cambodia & $1975-1979$ & 1988 \\
\hline Tuol Sleng & High School & Cambodia & $1975-1979$ & 1980 \\
\hline Navy School of Mechanics (ESMA) & Military Training School & Argentina & $1976-1983$ & 2004 \\
\hline Oklahoma Federal Building & Office Building & United States of America & 1995 & 2000 \\
\hline Ground Zero & Office Building & United States of America & 2001 & 2011 \\
\hline CTV Building & Office Building & New Zealand & 2011 & 2012 \\
\hline
\end{tabular}

Other Museum Monument

Table 6: Sites that have been adapted to a new use, listed by the year of event

This category, has been broken up into three sections, dependent on how the difficult history has been treated in the process of this new use and how important the difficult history is to the new use of the building. Museums and monuments will be treated as sub-categories here and analysed separately to better understand the patterns within each of these new uses. First will be the analysis of those moved to an entirely new use, independent of their difficult history. 
Transitioning a negatively connotated building to a new use is a difficult prospect. Whereas a museum new use project often separated the old from the surrounding new, in order to accentuate narratives that separate the past from the present, other new use projects typically require integration, in order for the site to be placed back within the urban fabric. These buildings may or may not acknowledge their negative history but this acknowledgement is not central to its current function. Another important aspect of buildings that were adaptively reused is that they were all in urban or suburban centres where they could be integrated over time. Many of these buildings were reused in conjunction with other developments, particularly on the sites of prisons or asylums which were purposely situated within large pockets of land which were ideal for development.

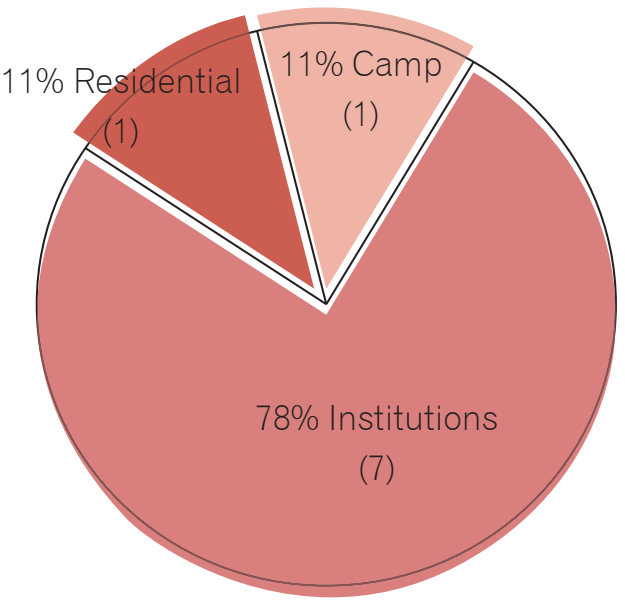

Building Type

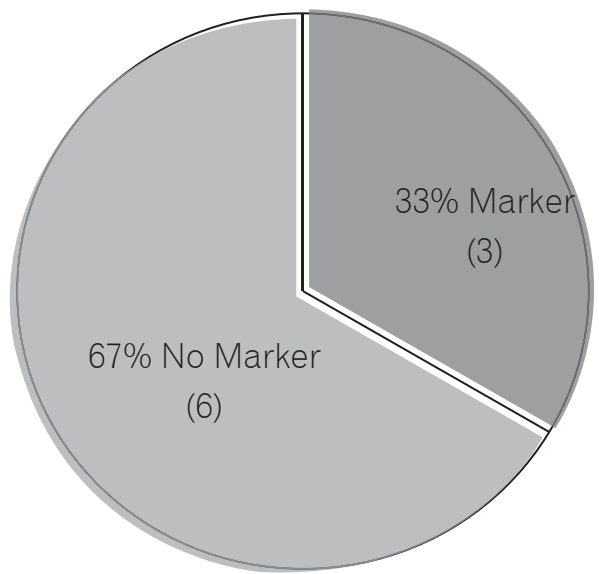

Marker of Difficult History

For a building to be converted to a new use the data suggests that a considerable amount of time must pass between event and new use. In some cases this is because vehement community opposition has halted development in other cases capital must be raised or projects tested for their feasibility. Independent adaptive reuse projects tend to occur when the events exist outside the collective or living memory (typically 1-2 generations, i.e. affected a person's grand parents by not their parents). This allows for those developing the place to reframe the event in a way that makes the development of hotels or housing a more viable prospect without having to acknowledge the negative memory. For a site to be developed in a shorter period of time, sites, such as the Liberty Hotel or Addington Jail, can acknowledge their negative history and even use it for marketing in order to connect the past and present and to publicly acknowledge the sites history. The data indicates that this

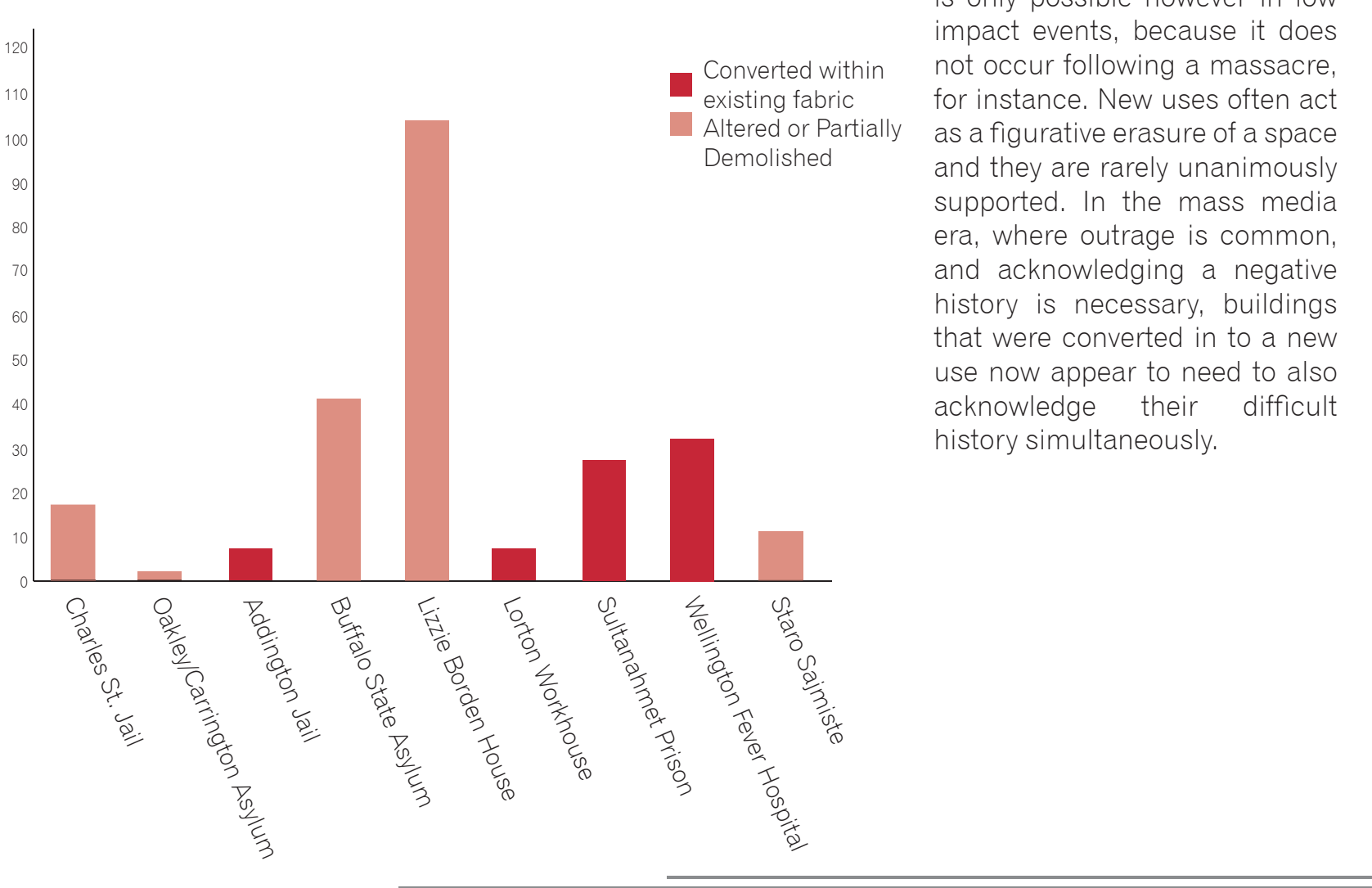


1800
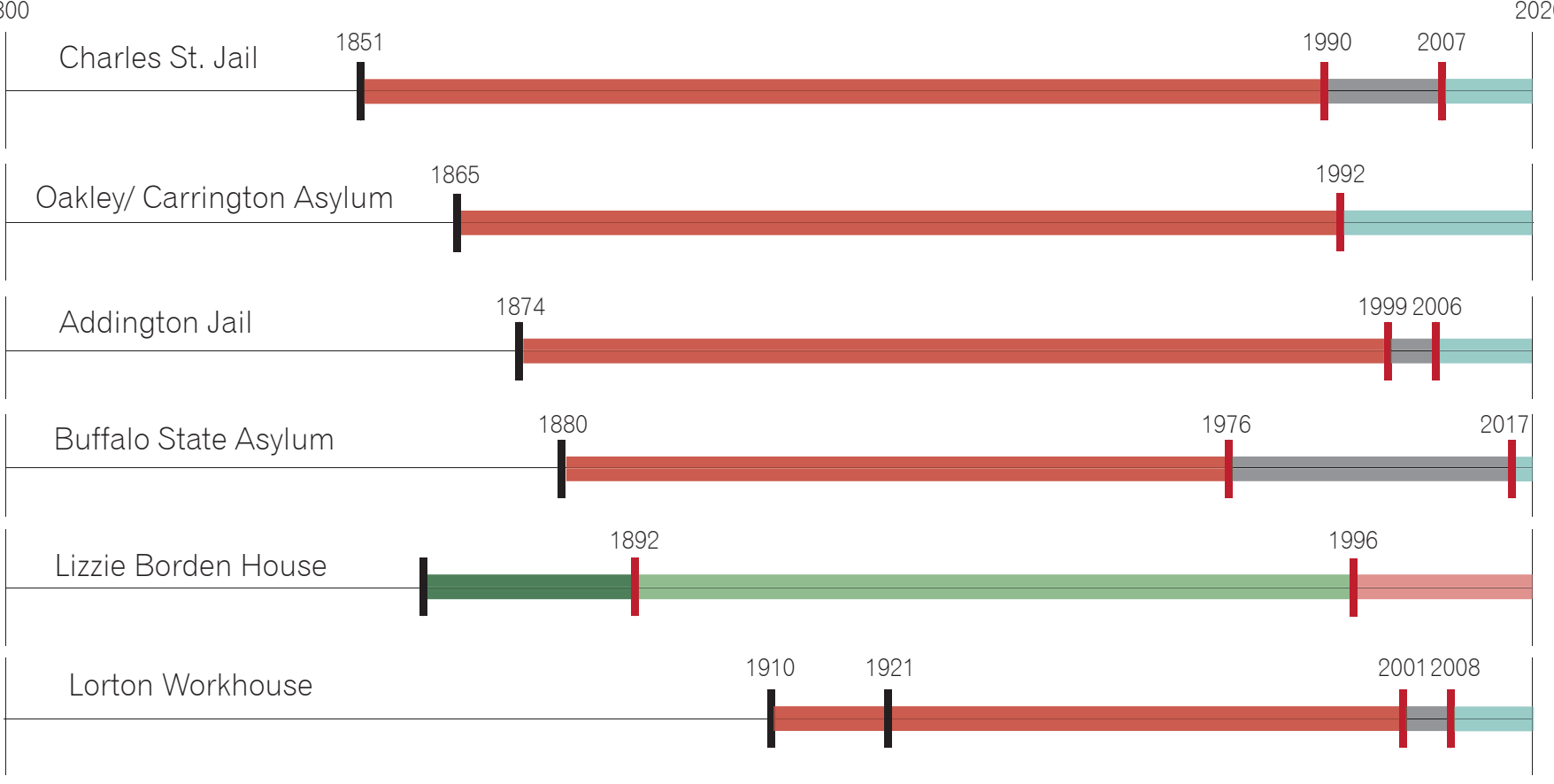

\begin{tabular}{|c|c|}
\hline Sultanahmet Prison & 1969 \\
\hline Wellington Fever Hospital & 1996 \\
\hline Staro Sajmiste & 19411941919 \\
\hline
\end{tabular}




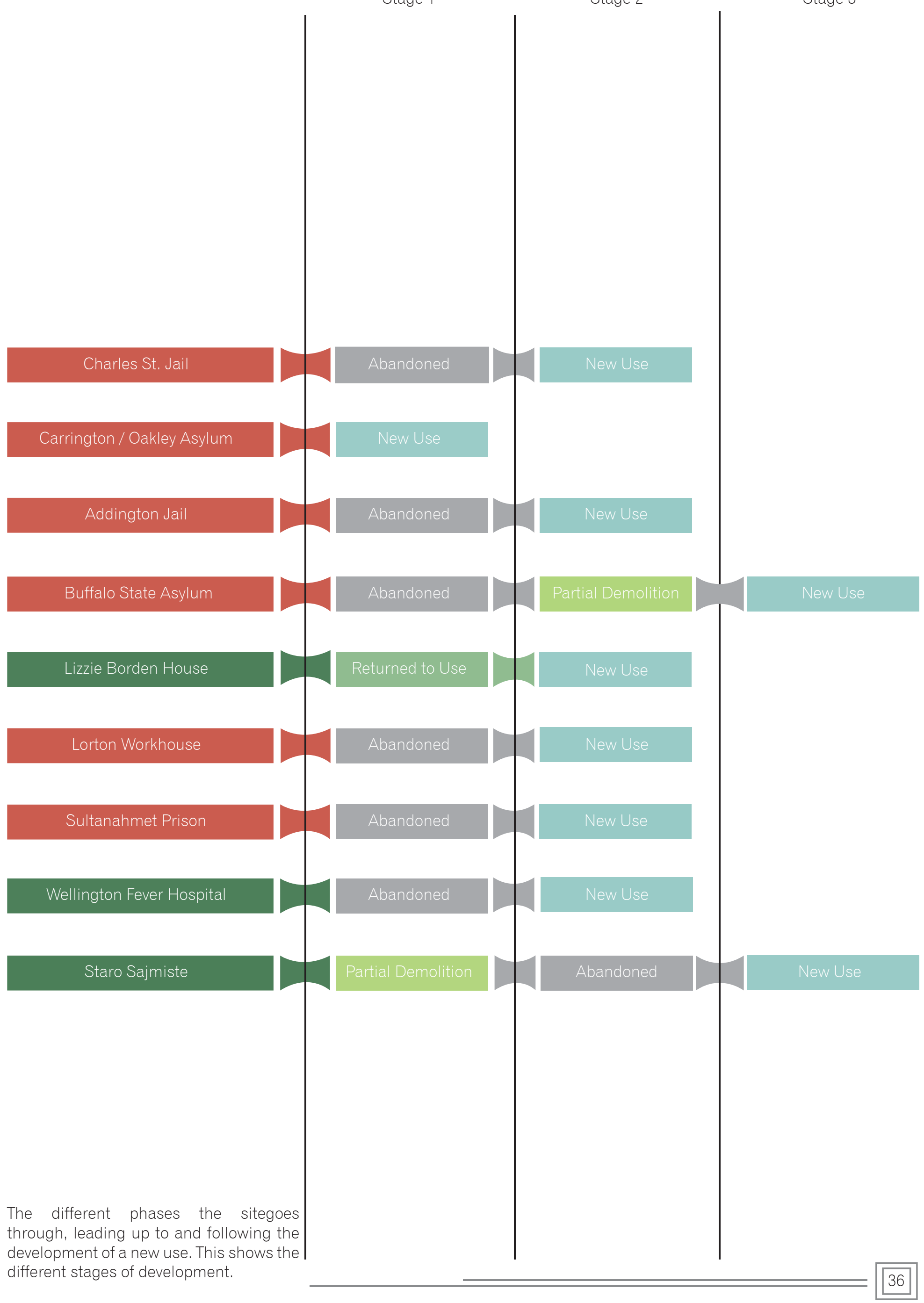




\section{New Use: Museum}

Museums that present the difficult history of a place to the public are a form of adaptive reuse that sees a site restored, adapted or allowed to decay in order to embody a certain historical narrative. They are a sub-category of new use which due to their dominance in the data and connection to the negative event require special attention.

\begin{tabular}{|c|c|c|c|c|}
\hline & Building Use & Place & Event & Museum \\
\hline House of Slaves & House & Senegal & $1776-1810$ & 1978 \\
\hline Robben Island & Prison & South Africa & $1781-1996$ & 1999 \\
\hline Eastern State Penitentiary & Prison & United States of America & $1829-1970$ & 1994 \\
\hline Port Arthur & Prison & Australia & $1833-1877 / 1996$ & 1979 \\
\hline Napier Prison & Prison & New Zealand & $1862-1993$ & 2002 \\
\hline Porirua Mental Asylum & Mental Asylum & New Zealand & $1887-1977$ & 1987 \\
\hline Hoa Lo Prison & Prison & Vietnam & $1889-1985$ & 1995 \\
\hline Dunedin Prison & Prison & New Zealand & $1896-2007$ & 2017 \\
\hline Presido Modelo & Prison & Cuba & $1928-1967$ & 1978 \\
\hline Alcatraz & Prison & United States of America & $1934-1968$ & 1972 \\
\hline Terezin Memorial & Town & Czech Republic & $1940-1945$ & 2002 \\
\hline Anne Frank House & House & Netherlands & $1940-1944$ & 1960 \\
\hline Sixth Floor Museum & Office Building & United States of America & 1963 & 1989 \\
\hline Tuol Sleng & High School & Cambodia & $1975-1979$ & 1980 \\
\hline Navy School of Mechanics (ESMA) & Military Traing School & Argentina & $1976-1983$ & 2004 \\
\hline
\end{tabular}

Table 5: Sites that have been developed into museum, presented separately here, listed by the year of negative event that the museums are markers of. 
Museums, defined here as interactive memorial markers to negative events, have become mandated parts of our public infrastructure. This may be, as Macdonald suggests, due to a highly informed society fascinated with the remnants of tragedy and death and intent in acknowledging past crimes to improve their moral credibility in the present ${ }^{11}$. Many negative heritage museums had strong political or cultural components intended to be educational, having already witnessed an 'unforgettable' event. In other cases they were more placid, merely a playground to bring a once invisible environment, such as a prison into the public realm.

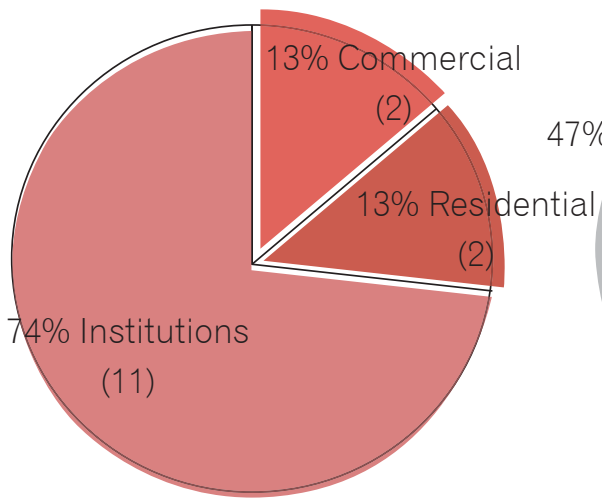

Building Type

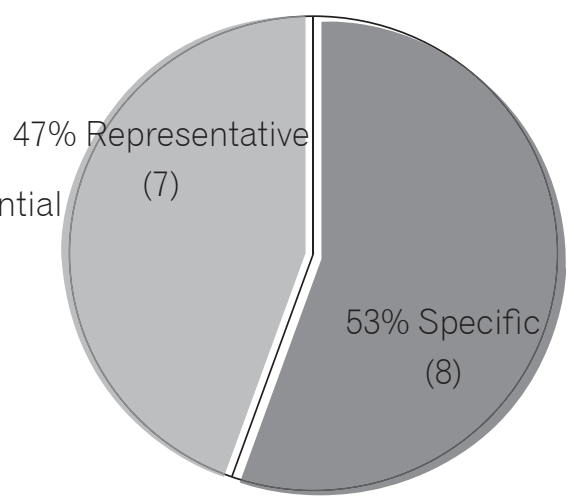

Museum Type

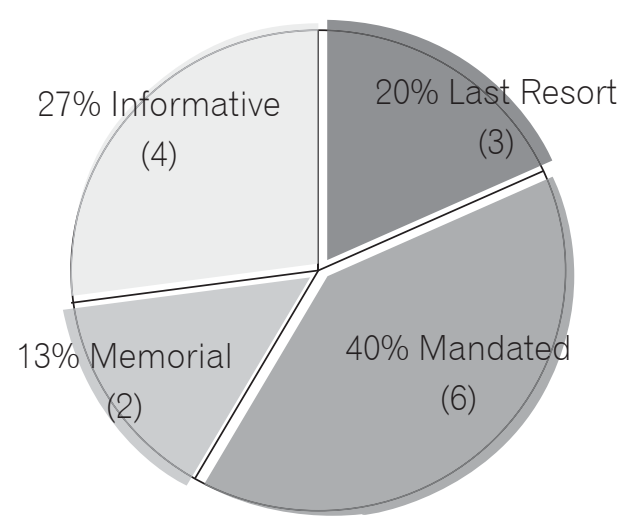

Creation Process

In some cases the creation of a museum appears to have been a last resort to save an aesthetically or architecturally important building, but in most of the cases looked at here, the museums were created because they were deemed to be more economically viable alternatives than returning a building back to its original use or to an alternative new use. The building of a museum is also consistent with the current socio-cultural climate where there is a need for a place to acknowledge its past atrocities ${ }^{12}$. To have a negative event unmarked is now a shame on a national fabric and seen as a global necessity. For example under the Stockholm declaration any country wishing to join the EU, must mark or memorialize all significant sites related to the Holocaust. Museums, whether at a local or national scale, allow for this acknowledgement while placing the past firmly in the past ${ }^{13}$.

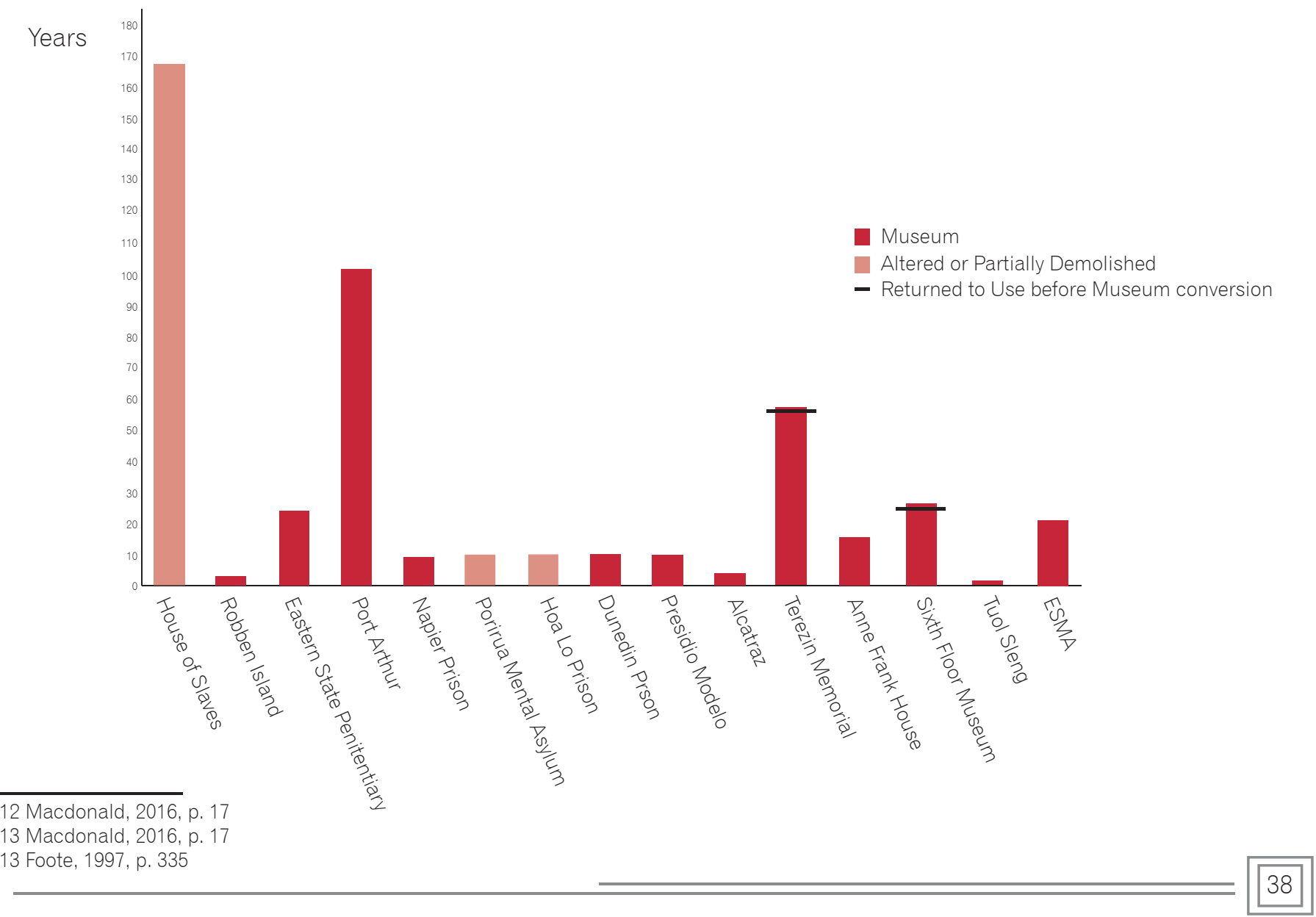


Robben Island
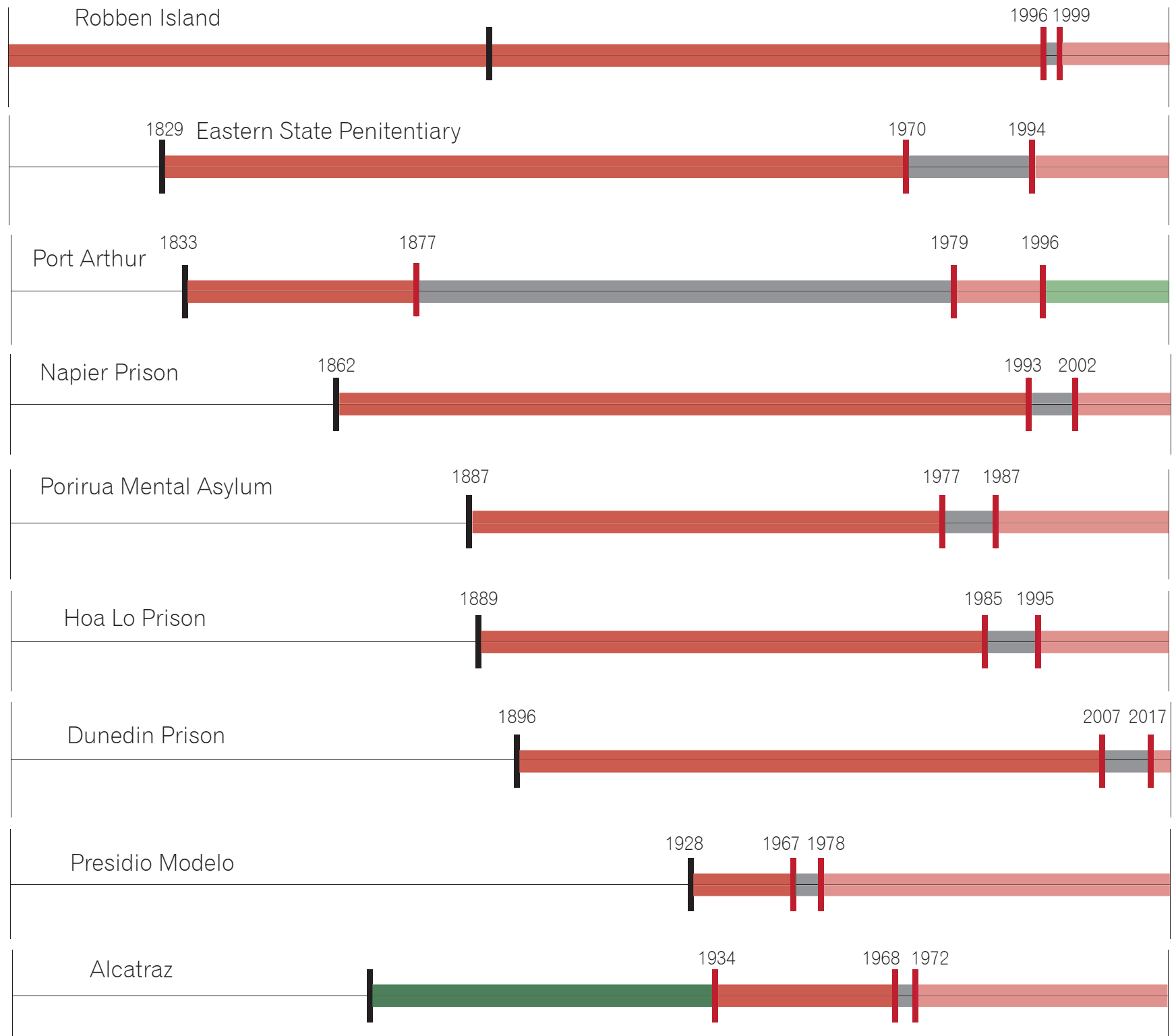

Terezin Memorial
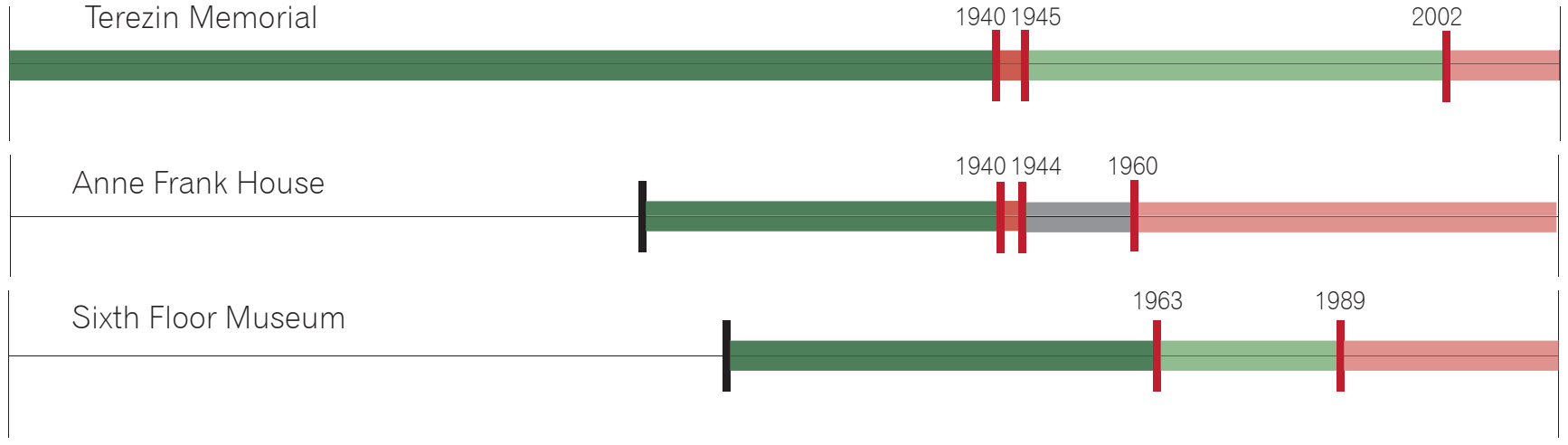

\begin{tabular}{|l|c|}
\hline Tuol Sleng & \\
\hline Navy School of Mechanics (ESMA) & 19761983 \\
\hline
\end{tabular}




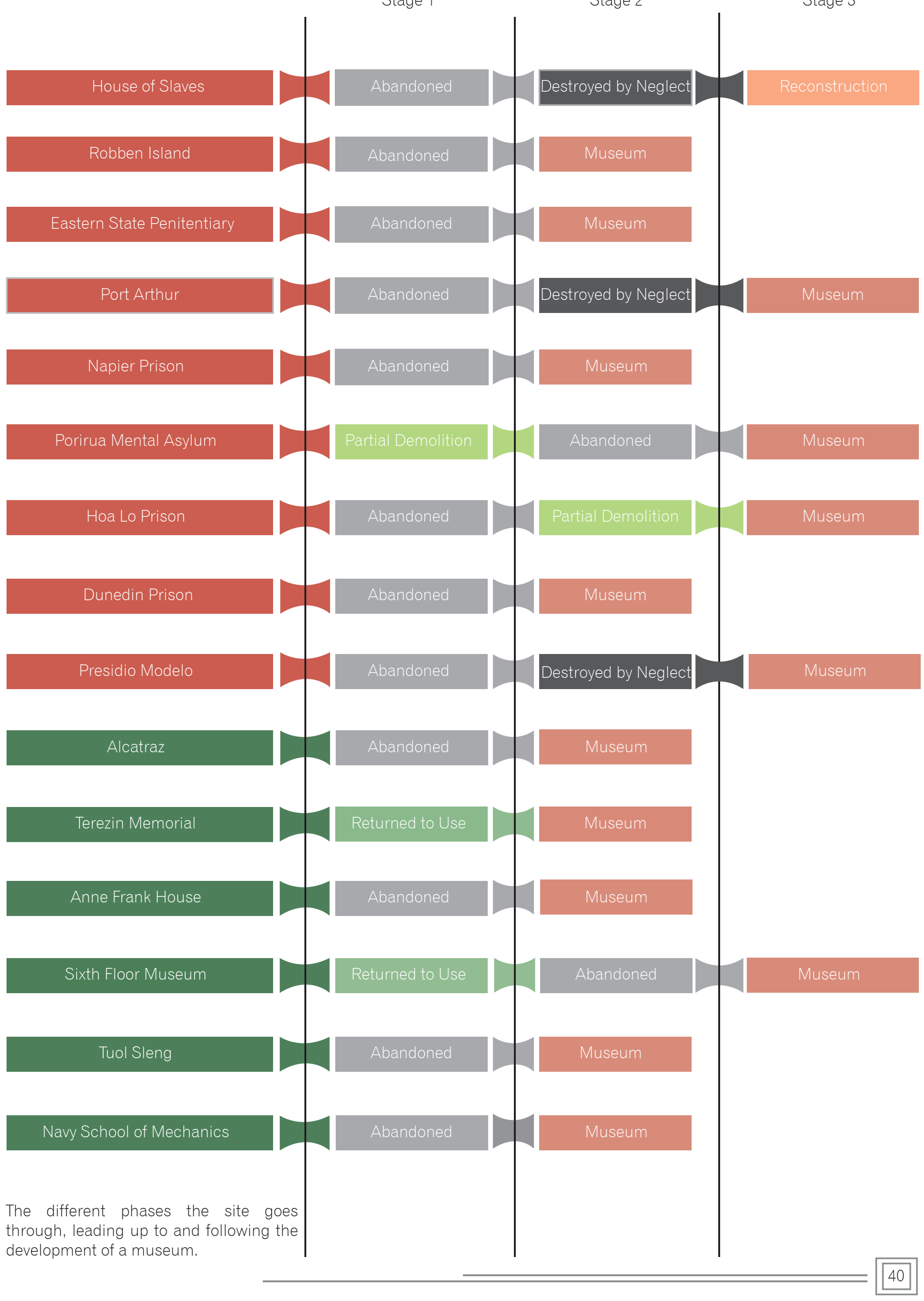




\section{New Use: Monument}

Sites that become monuments or memorials in the aftermath of an event informally, and then eventually formally, without any other active process (demolition, reuse, etc.), are exceptionally rare. There were very few sites that fall under this category, where no other active process took place. This appears to be because they usually occur when a site of mass casualty events, immediately becoming places of pilgrimage, and it is impossible to disassociate them from the event. Often the act of destroying the building and the resulting human casualties was the difficult heritage.

\begin{tabular}{c|c|c|c|c} 
& Building Type & Place & Event & Monumentalized \\
\hline Auschwitz - Birkenau & Concentration Camp & Poland & $1941-1945$ & 1947 \\
\hline Genbaku Dome & Exhibition Hall & Japan & 1945 & 1950 \\
\hline Choeung Ek & Orchard & Cambodia & $1975-1979$ & 1988 \\
\hline Oklahoma Federal Building & Office Building & United States of America & 1995 & 2000 \\
\hline Ground Zero & Office Building & United States of America & 2001 & 2011 \\
\hline CTV Building Site & Office Building & New Zealand & 2011 & 2012
\end{tabular}

Table 7: Sites that have been adapted preserved or reconstructed as monuments, present separately here, in order in which they were monumentalized 
Monuments are types of memorials, objects constructed or places preserved, explicitly created to commemorate an event. They are places of pilgrimage for victims, families and eventually tourists and have become essential parts of our global landscapes, markers of some of the world's most horrific atrocities. In the data analysed monuments were only erected in the case of high impact events. Often the building was destroyed in the event, leaving a void in its wake. Instantly a place of pilgrimage, these sites have drawn enough attention that a formal, state-sanctioned memorial was inevitable. Commercial buildings make up the majority of this small category. It appears that the characteristics that make commercial buildings easy to return to use in low impact events, (because they are inhabited by high volumes of people who do not identify with the place, and allows the memory of these events to fade), was what makes them targets for high impact atrocities. Events with victims entirely of one ethnic or minority group (eg. the Holocaust) or events with victims from a large cross-section of society (eg. the 9/11 Attacks) have deep societal impacts that make monuments inevitable.
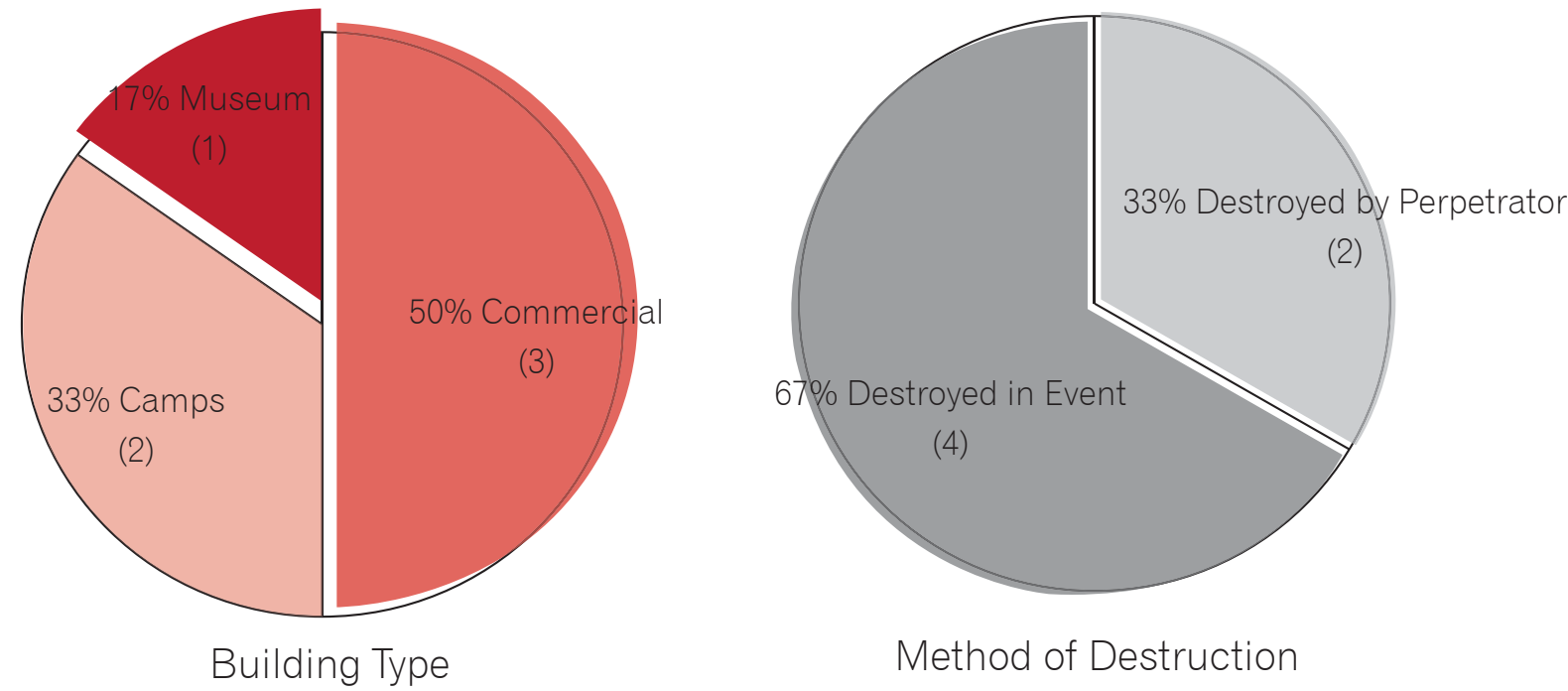

Method of Destruction

These places are effectively memorials from the moment that they become a place of pilgrimage and therefore the time it takes to create a formal monument appears to be less consequential to the outcome of the site. These sites were never again going to be viable for another use. Any return to original use or adaption into a new use would have been deemed disrespectful to the victims and highly insensitive. However, all of the data here is from events that still exist within 'living memory' and have become national monuments. Consequently it is not known whether or not a greater time period since the event would enable redevelopment for another purpose.

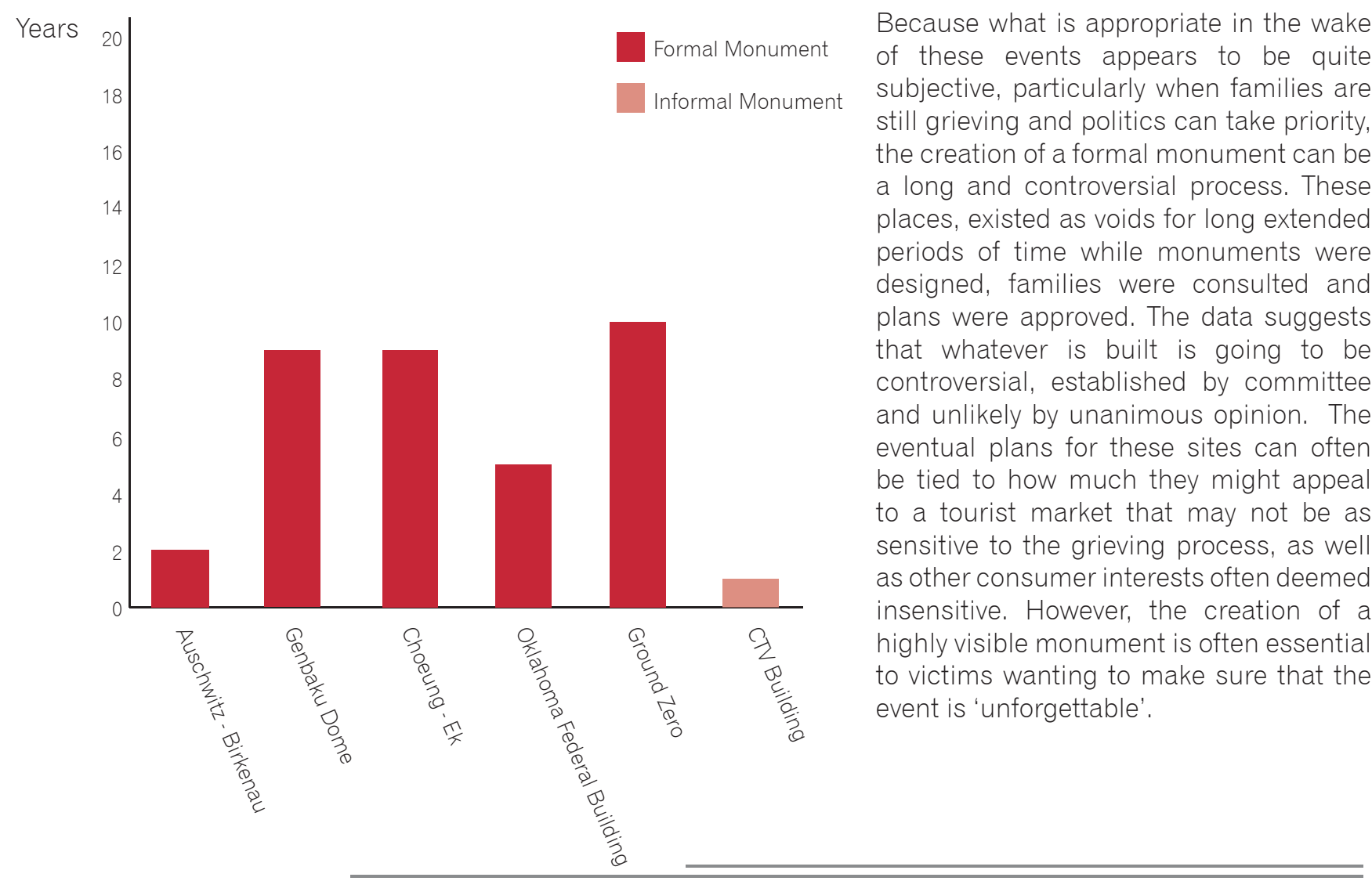




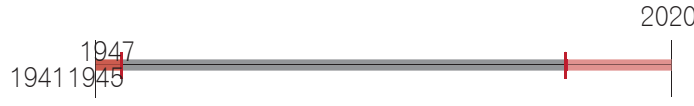

Auschwitz - Birkenau

Genbaku Dome

Choeung Ek

Oklahoma Federal Building

Ground Zero

CTV Building

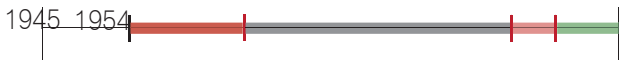

197519791988

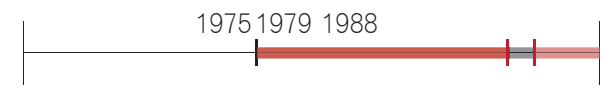

19952000

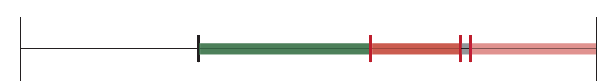

20012011

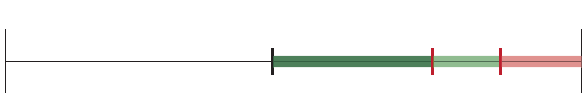

20112012 


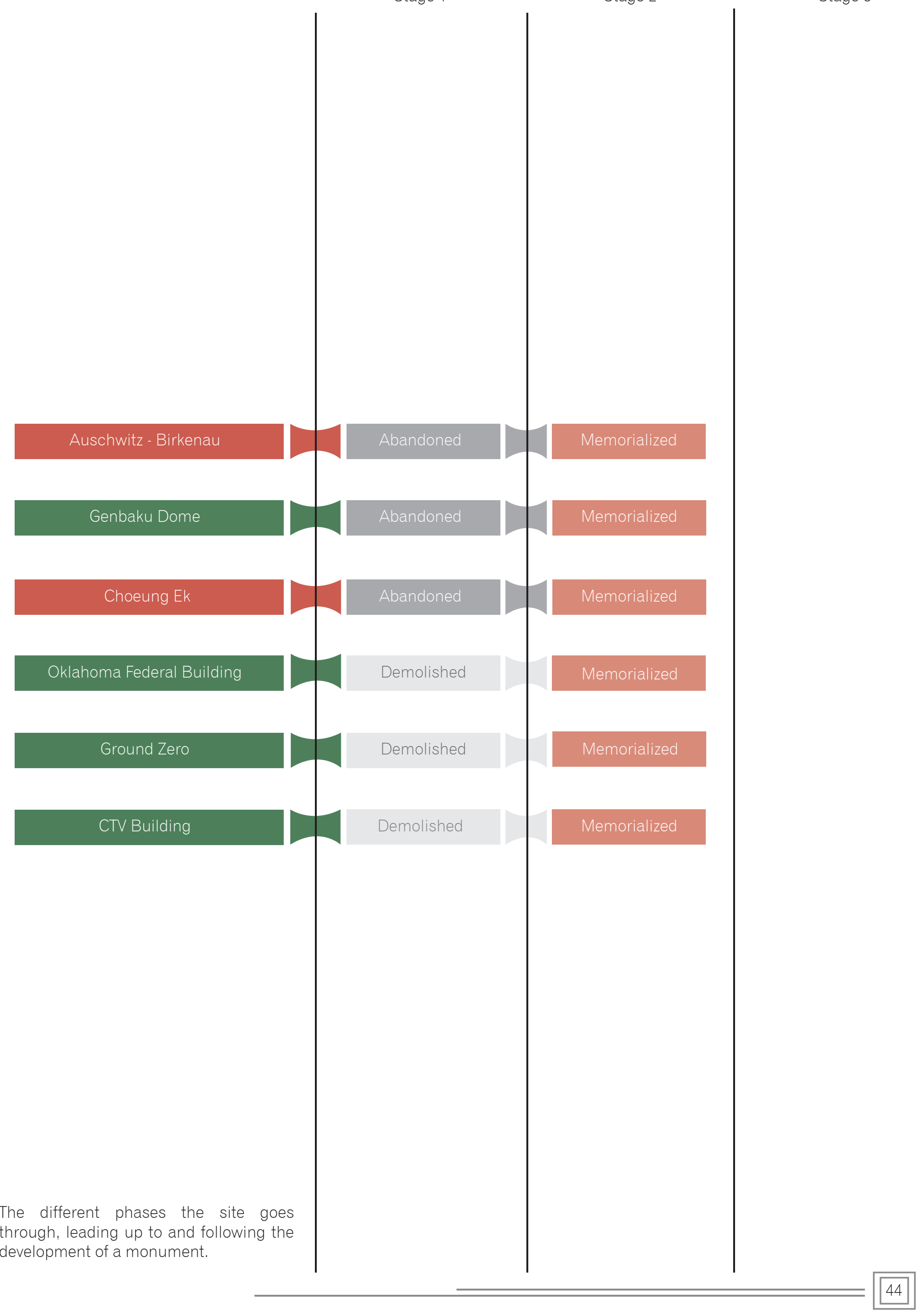




\section{Analysis: Building Types}

The initial category analysis revealed many patterns connecting various physical and social conditions with outcome. One of the most relevant to future research is the tie between building type and physical outcome. Different building types, have different societal, political and cultural conditions that not only tie them to certain events but to certain architectural outcomes. These patterns also create connections between location, aesthetic characteristics, nature of event, age of the building and timing of the event, but these themes can also be tied to building type. Here I will explain some of the themes around the three main building types (Institutional, Residential and Commercial) and how they may affect the fate of certain sites and potential uses for these sites.

\section{Outcome}

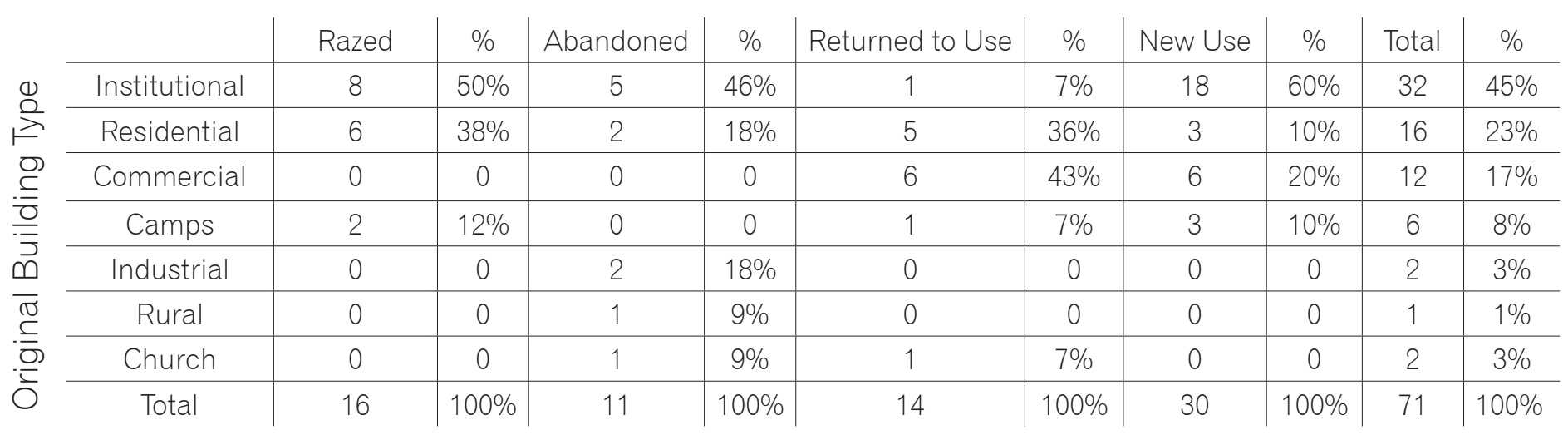

Table 8: Categories broken up into building types, revealing some of the initial patterns 


\section{Institutional}

Institutions as a building type make up a majority in this study. This is because they are largely government owned and in most cases have a large political component. My search method focussed on sites with media interest and public attention and their fate once they have outlived their use is of public interest (ie. possible selection bias). If institutional buildings are retained as heritage they remain within the public realm. If they carry a heavy political shame they are likely to either be razed or made into a museum. Timing is key regarding which of these occurs. If an institution is going to be razed then it will occur almost instantly, if the building avoids demolition in the immediate aftermath of its closure then it is likely to be turned into a museum or in some limited cases converted to a new use. Not only are these buildings costly to demolish, but, having once been an apparatus of the state, they are symbolic markers of national identity.

In the case of a new use, the lack of a homogenous opposition group is vital to new development. This is most likely to occur if the new development happened outside of living memory of the original event but is not vital if the event is less tragic (such as confinement compared to mass death) and has happened to a broad swathe of society. Those institutions that currently lie abandoned are more and more likely to be converted to a museum or new use while the current socio-cultural climate deems them viable.

As well as those sites that continue to be run by the government, there are also those that are bought by private owners, trusts and councils because they may offer a facility to a community, or because they are viable in the dark tourism market (e.g. ESMA, Addington Jail etc.). Financial viability might be a reason for governments to convert an institution to a new use or a museum beyond just its social or cultural meaning. In the private market rormer institutions, such as the Napier Prison can become a playground in the dark tourism market, a chance to bring a once invisible environment into the public eye. Other sites were more informative, undoubtedly the more politically charged, the more sober the experience. To be converted to a museum or a new use, an institution needed to be in an urban or suburban centre where visitor numbers are high and could be easily placed on a city's list of must see activities. Institutions that were once situated in town centres, now city centres, were the most successful of these and were more likely to be saved than demolished. 


\begin{tabular}{|c|c|c|c|c|c|}
\hline & Original Use & Urbanity & Event & Political Circumstances & Outcome \\
\hline Seacliff Mental Asylum & Mental Asylum & Rural & $\begin{array}{l}\text { Confinement / } \\
\text { Fire }\end{array}$ & & Razed \\
\hline Broad Street Prison & Prison & Urban & Confinement & Symbol of Colonialism & Razed \\
\hline Spandau Prison & Prison & Suburban & Confinement & $\begin{array}{l}\text { Housed } 7 \text { Nazi } \\
\text { Perpetrators }\end{array}$ & Razed \\
\hline Dunblane Primary School & Primary School & Suburban & Mass Murder & & Razed \\
\hline Carandiru Penitentiary & Prison & Urban & $\begin{array}{l}\text { Confinement / } \\
\text { Mass Murder }\end{array}$ & & Razed \\
\hline Long Kesh / Maze Prison & Prison & Rural & $\begin{array}{l}\text { Confinement / } \\
\text { Mass Suicide }\end{array}$ & $\begin{array}{l}\text { Symbol of Northern } \\
\text { Ireland Troubles }\end{array}$ & Razed \\
\hline Katingal Special Security Unit & Prison & Rural & Confinement & $\begin{array}{c}\text { Closed after } 3 \text { years amid } \\
\text { Royal Commission of } \\
\text { Enquiry }\end{array}$ & Razed \\
\hline Sandy Hook Elementary School & Primary School & Suburban & Mass Murder & & Razed \\
\hline Willard Asylum & Mental Asylum & Suburban & Confinement & & Abandoned \\
\hline Mt. Eden Prison & Prison & Urban & Confinement & & Abandoned \\
\hline Mt. Crawford Prison & Prison & Suburban & Confinement & & Abandoned \\
\hline Kimberley Centre & $\begin{array}{c}\text { Mental Deficiency } \\
\text { Hospital }\end{array}$ & Rural & $\begin{array}{l}\text { Confinement/ } \\
\text { Abuse }\end{array}$ & $\begin{array}{l}\text { Closed due to changing } \\
\text { government policy. }\end{array}$ & Abandoned \\
\hline Abu Gharib & Prison & Urban & $\begin{array}{l}\text { Confinement / } \\
\text { Mass Murder }\end{array}$ & $\begin{array}{c}\text { Closed due to fear would } \\
\text { be overrun by Sunni } \\
\text { insurgents }\end{array}$ & Abandoned \\
\hline Columbine High School & High School & Suburban & Mass Murder & & $\begin{array}{l}\text { Returned to } \\
\text { Use }\end{array}$ \\
\hline Alcatraz & Prison & Island & Confinement & & Museum \\
\hline Port Arthur & Prison & Rural & $\begin{array}{l}\text { Confinement / } \\
\text { Mass Murder }\end{array}$ & & Museum \\
\hline Tuol Sleng & High School & Urban & $\begin{array}{l}\text { Confinement / } \\
\text { Mass Murder }\end{array}$ & $\begin{array}{l}\text { Mass killings carried } \\
\text { out at prison by Khmer } \\
\text { Rouge during }\end{array}$ & Museum \\
\hline Porirua Mental Asylum & Mental Asylum & Suburban & Confinement & & Museum \\
\hline Eastern State Penitentiary & Prison & Urban & Confinement & & Museum \\
\hline Hoa Lo Prison & Prison & Urban & Confinement & $\begin{array}{c}\text { Built by French } \\
\text { Colonialists and abused } \\
\text { by North Vietnamese } \\
\text { during Vietnam War }\end{array}$ & Museum \\
\hline Robben Island & Prison & Island & Confinement & $\begin{array}{c}\text { Housed Apartheid } \\
\text { Political Prisoners } \\
\text { including Nelson } \\
\text { Mandela }\end{array}$ & Museum \\
\hline Presidio Modelo & Prison & Rural & $\begin{array}{l}\text { Confinement / } \\
\text { Hunger Strikes }\end{array}$ & $\begin{array}{l}\text { Housed Castro before } \\
\text { he came to power and } \\
\text { political prisoners after } \\
\text { he came to power. }\end{array}$ & Museum \\
\hline Napier Prison & Prison & Suburban & Confinement & & Museum \\
\hline Navy School of Mechanics & $\begin{array}{l}\text { Military Training } \\
\text { School }\end{array}$ & Urban & $\begin{array}{l}\text { Confinement/ } \\
\text { Mass Murder }\end{array}$ & $\begin{array}{l}\text { Mass Killlings carried } \\
\text { out at ESMA by military } \\
\text { government }\end{array}$ & Museum \\
\hline Dunedin Prison & Prison & Urban & Confinement & & Museum \\
\hline Oakley / Carrington Asylum & Mental Asylum & Urban & Confinement & & New Use \\
\hline Sultanahmet Prison & Prison & Urban & Confinement & & New Use \\
\hline Addington Jail & Prison & Urban & Confinement & & New Use \\
\hline Charles St. Jail & Prison & Urban & Confinement & & New Use \\
\hline Lorton Workhouse & Prison & Suburban & Confinement & & New Use \\
\hline Wellington Fever Hospital & Fever Hospital & Urban & Mass Death & & New Use \\
\hline Buffalo State Asylum & Mental Asylum & Urban & Confinement & & New Use \\
\hline
\end{tabular}




\section{Residential}

Homes are often considered to be sacred, safe havens. When atrocities happen within homes the events are deemed to violate these communal rules. This violation often invokes hatred and shame in a community, when a cruel or tragic event happens within this safe haven, the violation sees the house erased, whether this is literally or figuratively seemed to be a factor of socio-economic circumstance. In lower socio-economic communities, where the community is more closely bound, and home is not just a reflection of wealth, but a safe haven, these homes were destroyed, occasionally by the community themselves, or mandated by a council concerned about a place becoming a beacon for criminal behaviour in a lower socio-economic neighbourhood ${ }^{14}$. In higher socio-economic neighbourhoods the houses were returned to use (generally only after a change of ownership), remnants of the event were erased from the property and it was given a second life. There are potentially many reasons for this. The fact that these houses were undoubtedly worth a lot more financially is a likely a factor. It was pointed out when the run-down Bain house was destroyed that the land would be worth a lot more to sell without the house on it ${ }^{15}$.

The two residential sites that were abandoned (Jonestown and Anlong Veng) are the most politically potent of all the sites and other case studies suggest that they are unlikely to see their fate resolved in a straightforward manner or in the near future. The two residential sites that have become museums (Anne Frank House and House of Slaves) have become representative of two of the most arguably potent cultural issues of the twentieth century, the Nazis and slavery, and have become symbolic to the resistance of these atrocities in a very relatable and humble way within the fabric of the home.

There are exceptions to the patterns. Peter Tobin's house was the first, (where in a geographically and criminally similar case ten years earlier, the West house was demolished), to be saved and returned to use. The local council gave the house to a lower-middle class family who were first home buyers, arguing that it would be unethical to demolish a house during a housing crisis when it could be feasibly returned to use and given to someone who needs it. This context, the political and social issues external to any specific event, are essential to understanding the outcomes of these sites. Another exception is the Lizzie Borden house, which was converted to a hotel in the 1990s after having been returned to its original use for more than a 100 years. This exception appears to have been due to the passing of time. It is the only residential place to have been subject to an event outside of the twentieth century and appears to have only been adapted into a new use because of the changing perception around how we commemorate negative events.

\begin{tabular}{|c|c|c|c|c|c|}
\hline & Building Use & Social-Economic & Urbanity & Political Circumstances & Outcome \\
\hline David Grays Crib & House & Lower & Suburban & & Razed \\
\hline Mt. Carmel, Waco & $\begin{array}{l}\text { Residential } \\
\text { Compound }\end{array}$ & Lower & Rural & $\begin{array}{l}\text { Sparked by Federal } \\
\text { Siege of Property }\end{array}$ & Razed \\
\hline The Bain House & House & Lower & Suburban & & Razed \\
\hline West Murder House & House & Lower & Suburban & & Razed \\
\hline Hampshire St. Horror House & House & Lower & Suburban & & Razed \\
\hline Fritzl Basement & House & Middle & Urban & & Razed \\
\hline Jonestown & $\begin{array}{l}\text { Residential } \\
\text { Compound }\end{array}$ & Lower-Middle & Rural & $\begin{array}{c}\text { Communists escaping } \\
\text { Capitalist American } \\
\text { Society }\end{array}$ & Abandoned \\
\hline Anlong Veng & $\begin{array}{l}\text { Communal } \\
\text { Housing Area }\end{array}$ & Lower & Rural & $\begin{array}{l}\text { Khmer Rouge } \\
\text { Stronghold }\end{array}$ & Abandoned \\
\hline White House Farm & House & Upper & Rural & & Returned to Use \\
\hline Menendez Murder House & House & Upper & Suburban & & Returned to Use \\
\hline Simpson Murder House & House & Upper & Suburban & & Returned to Use \\
\hline Lundy Murder House & House & Middle & Suburban & & Returned to Use \\
\hline Peter Tobin House & House & Lower & Suburban & & Returned to Use \\
\hline Anne Frank House & House & Middle & Urban & $\begin{array}{l}\text { Hiding from Nazi } \\
\text { Persecution }\end{array}$ & Museum \\
\hline House of Slaves & Slave Port & Lower & Island & $\begin{array}{l}\text { Eighteenth Century } \\
\text { Slave Port }\end{array}$ & Museum \\
\hline Lizzie Borden House & House & Upper-Middle & Suburban & & New Use \\
\hline
\end{tabular}

Table 10: Residential Buildings, showing characteristics they could be deemed a pattern linking to outcome 


\section{Commercial}

No commercial buildings I looked at had been demolished. There seems to be multiple reasons for this. These might be:

- That commercial buildings are not as sacred as residential or as politically potent as institutions

- Are frequented by many people and therefore are easy to other and return to use.

- Are most often in urban centres, where the chances of creating a long-term void is high in the case of demolition

- Are generally privately owned, meaning that their fate is not influenced as much by public outcry as institutions are. Private owners might be less likely to shoulder the financial loss of demolishing and rebuilding a place of negative memory in contrast to a government more at the mercy of public opinion.

The commercial buildings that have been destroyed are those that were destroyed in the event. Commercial buildings are likely prime targets for terrorists because during the day they are filled with large groups of people. These high impact events left lasting traces on the collective memory and on the individual sites meaning their choices for redevelopment were limited. These are where voids become markers and later memorials to tragedies that have shaken the very foundations of our society. In the case of high impact events these places become ruptures in the urban fabric, designed to invoke lasting memory.

Commercial buildings if they were going to be returned to use were done so very quickly, generally as a matter of efficiency. For example, public transport, such as the London Underground, cannot afford not to run and so, regardless of the high impact of the event, it appears that such sites will likely be returned to use. Pripyat and Bhopal are two outliers in the below list because they both suffered from massive chemical fallout of which affected millions of people and will continue to affect millions of peoples.

\begin{tabular}{|c|c|c|c|c|c|}
\hline & Building Use & Urbanity & Survival Record & Political Circumstances & Outcome \\
\hline Pripyat & Town & Urban & Intact & & Abandoned \\
\hline Bhopal Chemical Plant & $\begin{array}{l}\text { Industrial } \\
\text { Complex }\end{array}$ & Urban & Intact & $\begin{array}{l}\text { Extended Court } \\
\text { battle for victim } \\
\text { compensation }\end{array}$ & Abandoned \\
\hline Ballantynes Department Store & Retail Store & Urban & Destroyed by Fire & & Returned to Use \\
\hline Wellington Trades Hall & Office Building & Urban & Intact & & Returned to Use \\
\hline Invincible House & Office Building & Urban & Intact & & Returned to Use \\
\hline Long Island Railroad & Transportation & Urban & Intact & & Returned to Use \\
\hline London Underground & Transportation & Urban & $\begin{array}{c}\text { Carriages Effected } \\
\text { Destroyed }\end{array}$ & & Returned to Use \\
\hline Lindt Cafe & Cafe & Urban & Intact & & Returned to Use \\
\hline Sixth Floor Museum & Office Building & Urban & Intact & $\begin{array}{l}\text { Most infamous } \\
\text { assassination in } \\
\text { modern history }\end{array}$ & Museum \\
\hline Terezin Memorial & Town & Urban & Intact & $\begin{array}{l}\text { World Monuments } \\
\text { Fund pressured to } \\
\text { memorialize negative } \\
\text { history }\end{array}$ & Museum \\
\hline Genbaku Dome & Museum & Urban & $\begin{array}{c}\text { Partially Destroyed } \\
\text { by Bombing }\end{array}$ & End of WWII & Monument \\
\hline Oklahoma Federal Building & Office Building & Urban & $\begin{array}{l}\text { Destroyed by } \\
\text { Bombing }\end{array}$ & $\begin{array}{c}\text { Backlash to handling of } \\
\text { Waco Siege and Ruby } \\
\text { Ridge }\end{array}$ & Monument \\
\hline Ground Zero & Office Building & Urban & $\begin{array}{l}\text { Destroyed by } \\
\text { Plane }\end{array}$ & $\begin{array}{c}\text { Beginning of War on } \\
\text { Terror }\end{array}$ & Monument \\
\hline CTV Building Site & Office Building & Urban & $\begin{array}{l}\text { Destroyed by } \\
\text { Earthquake }\end{array}$ & & Monument \\
\hline
\end{tabular}

Table 11: Commercial Buildings, showing characteristics they could be deemed a pattern linking to outcome 



\section{Analysis: Site Management}

An important aspect of developing a process within this thesis is understanding how sites were managed in the past. Building on the analysis of building types, this section draws links between each building's original use, the event, the outcome by category and then the outcome by physical use. This will help to connect what actually happened on site and how the site was treated. This section also identifies various mechanisms for engaging with memory on the site, whether by removal, manipulation or occupation. The thesis assumes that an understanding and development of these mechanisms will be able to be used to architecturalise various outcomes on a site.

This section is divided into two parts: high impact and low impact events. The scale of an event cannot always be measured by the number of people who died, or were affected. As Tunbridge and Ashworth state, the number of victims has little influence on deployment of heritage; the nature of human imagination is such that it resists the extension of empathy beyond small groups. Neither can it be defined by the type of event that it is. Some murders or terrorist attacks capture the public imagination more strongly than others dependent on the who, the where and other social and political conditions taking place at the time. However an event can be measured by its impact, the way it lasts in the collective memory, perhaps becoming a cultural reference, with an anniversary that is continually memorialised and facts that are known long after the event has happened. The nature of negative heritage means that it has the ability to fascinate and engage the general public, but how negative heritage goes on to influence and engage the general public over time appears to be a better way to measure impact and differentiate how the sites are treated. The data used to evaluate low and high impact events is in Appendix $A^{16}$. The definitions used in this section are:

Low Impact Event - Has a low number of people dead or injured or has an unknown scale of impact, is not well known or memory has faded, is an event that has been replicated across many places and may be important at a local level but tends to be included in a general grouping in the collective memory.

High Impact Event - Has a high number of people dead or injured, has a strong political or social component or symbolism, has led to lasting regulatory changes, invokes a strong visceral reaction due to the nature of the victims or perpetrators

16 The impact of an event on a wider community or society and how it can be measured is outside the scope of this research and is a point of further study 
Building Use

Broad Street Prison, Nigeria

Prison

Event

Confinement

Dunblane Primary School, UK

Primary School

Featherston POW Camp, NZ

Hampshire St. Horror House, NZ

Katingal Special Security Unit, Australia

Seacliff Mental Asylum, NZ

Buckeberg, Germany

Kimberley Centre, NZ

Mt. Crawford, NZ

Mt. Eden, NZ

Willard Asylum, USA

Ballantynes Department Store, NZ

Invincible House, NZ

Lindt Cafe, Australia

Long Island Railroad, USA

Lundy Murder House, NZ

Menendez Murder House, USA

Peter Tobin House, UK

Wellington Trades Hall, NZ

White House Farm, UK

Addington Jail, NZ

Buffalo State Asylum, USA

Charles St. Jail, USA

Lizzie Borden House, USA

Lorton Workhouse, USA

Oakley / Carrington Asylum, NZ

Sultanahmet Prison, Turkey

Wellington Fever Hospital, NZ

Alcatraz, USA

Dunedin Prison, NZ
Eastern State Penitentiary, USA
Hoa Lo Prison, Vietnam

House of Slaves, Senegal

Napier Prison, NZ

Port Arthur, Australia

Porirua Mental Asylum, NZ

Presidio Modelo, Cuba
Internment

Camp

House

Prison

Mental Asylum

Festival Grounds

Mental Hospital

Prison

Prison

Mental Asylum

Retail

Office Building

Cafe

Transportation

House

House

House

Office Building

House

Prison

Mental Asylum

Prison

House

Prison

Mental Asylum

Prison

Fever Hospital

Prison

Prison

Prison

Prison

Slave Port

Prison

Prison

Mental Asylum

Prison

Prison

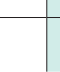

Mass Murder
Confinement/
Mass Murder

Murder

Confinement

Confinement/

Fire

Nazi Propoganda

Confinement / Abuse

\begin{tabular}{c|c} 
Confinement & Abandoned \\
Confinement & Abandoned \\
\hline Confinement & Abandoned
\end{tabular}

Fire

Murder

Returned to Use

Returned to Use

Mass Murder

Returned to Use

Mass Murder Returned to Use

Murder

Murder

Murder

Terrorism

Murder

Confinement

Confinement

Confinement

Murder

Confinement

Returned to Use

Returned to Use

Returned to Use

Returned to Use

Returned to Use

New Use

New Use

Confinement

Confinement

Mass Death

Confinement

New Use

New Use

New Use

New Use

New Use

New Use

Confinement Museum

Confinement

Confinement

Museum

Museum

Confinement

Museum

Slavery

Confinement

Confinement /

Mass Murder

Confinement

Confinement
Museum

Museum

Museum

Museum

Museum
Mechanism

Current Use

Partial

Total Demolition Reconstruction -

Public Park

Memorial

Demolition

Total Demolition

Memorial

Burning

Public Park

Total Demolition

Partial

Demolition

Abandonment

Abandonment

Housing

Development

Abandonment

Abandonment

Abandonment

Partial

Demolition

Re-Occupation

Re-Surfacing

Re-Surfacing

Re-Occupation

Re-Occupation

Re-Occupation

Re-Surfacing

Re-Occupation

Re-Surfacing

Partial

Demolition

Public Reserve

Re-Surfacing

Re-Surfacing

Re-Surfacing

Re-Surfacing

Re-Surfacing

Re-Surfacing

Entombment \&

Re-Surfacing

Re-Surfacing

Abandonment

Partial

Demolition

Abandonment

Abandonment

Abandonment

Retail

Office Building

Cafe

Transportation

House

House

House

Office Building

House

Backpackers

Hotel

Hotel

Hotel

Arts Centre

University

Campus

Hotel

SPCA

Tourist Attraction

- National Park

Service

Tourist Attraction

Tourist Attraction

Museum

Museum

Tourist Attraction

Partial

Demolition

Abandonment

Museum

Museum

Table 12: Low Impact Events, showing building use, event, outcome, mechanism and new use. 


\section{Low Impact Events}

Memorial

Cafe

Office Building
Terrorism

Public Park

Office Building

Housing

Hotel
Public Park

Hotel

\section{Education Facility}

Tourist Attraction

Museum
Public Park

Retail

SPCA

Museum

Aside from monuments, a category very much defined by the high impact event, all of the categories include some sites subject to low impact events. More interesting than the categories that they eventually fall into are the connections between event and their final use. Mass murders, defined by the killing of four or more people, nearly always invite some kind of memorial or recognition. Even if they appear to have had a low overall impact they were always given some designation or marker. The exception here is the Long Island Railroad, which used the implicated carriages, retired in 1995, as memorials. Aside from this, low impact events seem to invite new uses, even when the building is razed public parks pop up in their place. Tourist attractions, hotels and housing seem to, with time, be able to be co-exist with the memory of the original event, whether this be confinement, murder or terrorism.
Broad Street Prison

Dunblane Primary School

Featherston POW Camp

Hampshire St. House

Katingal Special Security

Seacliff Mental Asylum

Buckeberg

Kimberley Centre

Mt. Crawford

Mt. Eden

Willard Asylum

Ballantynes

Invincible House

Lindt Cafe

Long Island Railroad

Lundy House

Menenendez House

Tobin House

Wellington Trades Hall

White House Farm

Addington Jail

Buffalo State Asylum

Charles St. Jail

Borden House

Lorton Workhouse

Carrington Asylum

Sultanahmet Prison

Wellington Fever Hospital

Alcatraz

Dunedin Prison

Eastern State

Hoa Lo Prison

House of Slaves

Napier Prison

Port Arthur

Porirua Mental Asylum

Presidio Modelo 


\begin{tabular}{|c|c|c|c|c|c|}
\hline & Building Use & Event & Outcome & Mechanism & Current Use \\
\hline The Bain House, NZ & House & Mass Murder & Razed & Burning & New House \\
\hline Carandiru Penitentiary, Brazil & Prison & $\begin{array}{l}\text { Confinement / } \\
\text { Mass Murder }\end{array}$ & Razed & $\begin{array}{c}\text { Partial } \\
\text { Demolition }\end{array}$ & Public Park \\
\hline David Grays Crib, NZ & House & Mass Murder & Razed & Burning & - \\
\hline Fritzl Basement, Austria & House & Confinement & Razed & Filled In & Apartments \\
\hline Long Kesh / Maze Prison, UK & Prison & $\begin{array}{l}\text { Confinement / } \\
\text { Mass Suicide }\end{array}$ & Razed & $\begin{array}{c}\text { Partial } \\
\text { Demolition }\end{array}$ & - \\
\hline Manzanar Internment Camp, USA & $\begin{array}{l}\text { Internment } \\
\text { Camp }\end{array}$ & Confinement & Razed & Total Demolition & $\begin{array}{c}\text { Partially Recon- } \\
\text { stucted - Public } \\
\text { Park }\end{array}$ \\
\hline Mt. Carmel, Waco, USA & $\begin{array}{l}\text { Residential Com- } \\
\text { pund }\end{array}$ & Mass Murder & Razed & Burning & Memorial \\
\hline $\begin{array}{c}\text { Sandy Hook Elementary School, } \\
\text { USA }\end{array}$ & Primary School & Mass Murder & Razed & Total Demolition & $\begin{array}{l}\text { New School } \\
\text { constructed on } \\
\text { site }\end{array}$ \\
\hline Spandau Prison, Germany & Prison & Confinement & Razed & Total Demolition & Shopping Mall \\
\hline West Murder House, UK & House & Murder & Razed & Total Demolition & Public Walkway \\
\hline Abu Gharib, Iraq & Prison & $\begin{array}{l}\text { Confinement / } \\
\text { Mass Murder }\end{array}$ & Abandoned & Abandonment & - \\
\hline Anlong Veng, Cambodia & $\begin{array}{l}\text { Communal } \\
\text { Housing Area }\end{array}$ & $\begin{array}{l}\text { Perpetrator } \\
\text { Housing }\end{array}$ & Abandoned & Abandonment & Tourist Attraction \\
\hline Ayodha Mosque / Temple, India & Church & Religious Conflict & Abandoned & Abandonment & - \\
\hline Bhopal Chemical Plant, India & $\begin{array}{l}\text { Industrial } \\
\text { Complex }\end{array}$ & $\begin{array}{c}\text { Chemical Gas } \\
\text { Leak }\end{array}$ & Abandoned & Abandonment & - \\
\hline Jonestown, Guyana & $\begin{array}{l}\text { Residential } \\
\text { Compound }\end{array}$ & Mass Suicide & Abandoned & Abandonment & - \\
\hline Pripyat, Ukraine & Town & Nuclear Fallout & Abandoned & Abandonment & - \\
\hline Columbine High School, USA & High School & Mass Murder & Returned to Use & $\begin{array}{c}\text { Partial } \\
\text { Demolition }\end{array}$ & High School \\
\hline Emanuel AME, USA & Church & Mass Murder & Returned to Use & Re-Occupation & Church \\
\hline London Underground, UK & Transportation & Terrorism & Returned to Use & Re-Occupation & Transportation \\
\hline Simpson Murder House, USA & House & Murder & Returned to Use & Re-Occupation & House \\
\hline Utoya Island, Norway & Island Camp & Mass Murder & Returned to Use & $\begin{array}{c}\text { Partial } \\
\text { Demolition }\end{array}$ & Camp \\
\hline Staro Sajmiste, Serbia & Fair Grounds & Genocide & New Use & $\begin{array}{c}\text { Partial } \\
\text { Demolition }\end{array}$ & Residential Area \\
\hline Anne Frank House, Netherlands & House & Confinement & Museum & Re-Surfacing & $\begin{array}{l}\text { Exhibiton to the } \\
\text { Promotion of } \\
\text { Human Rights }\end{array}$ \\
\hline $\begin{array}{l}\text { Navy School of Mechanics } \\
\text { (ESMA), Argentina }\end{array}$ & $\begin{array}{l}\text { Military Training } \\
\text { School }\end{array}$ & Mass Murder & Museum & Re-Surfacing & Museum \\
\hline Robben Island, South Africa & Prison & Confinement & Museum & Re-Surfacing & Museum \\
\hline Sixth Floor Museum, USA & Office Building & Murder & Museum & Re-Surfacing & Museum \\
\hline Terezin Memorial, Czech Republic & Town & Genocide & Museum & Abandonment & Memorial \\
\hline Tuol Sleng, Cambodia & High School & Genocide & Museum & Re-Surfacing & Museum \\
\hline Auschwitz-Birkenau, Poland & $\begin{array}{l}\text { Concentration } \\
\text { Camp }\end{array}$ & Genocide & Monument & Abandonment & Memorial \\
\hline Choeung Ek, Cambodia & Orchard & Genocide & Monument & Memorial Marker & Memorial \\
\hline CTV Building, NZ & Office Building & Earthquake & Monument & Total Demolition & Memorial \\
\hline Genbaku Dome, Japan & Museum & Bombing & Monument & Abandonment & Memorial \\
\hline Ground Zero, USA & Office Building & Terrorism & Monument & Memorial Marker & Memorial \\
\hline Oklahoma Federal Building, USA & Office Building & Terrorism & Monument & Total Demolition & Memorial \\
\hline
\end{tabular}

Table 13: High Impact Events, showing building use, event, outcome, mechanism and new use. 


\section{High Impact Events}

Public Park

Apartments

Shopping Mall

Museum

\section{Confinement}

Attraction

Memorial

\section{Housing}

Public Park

Memorial

School

Church

Museum

\section{Other}

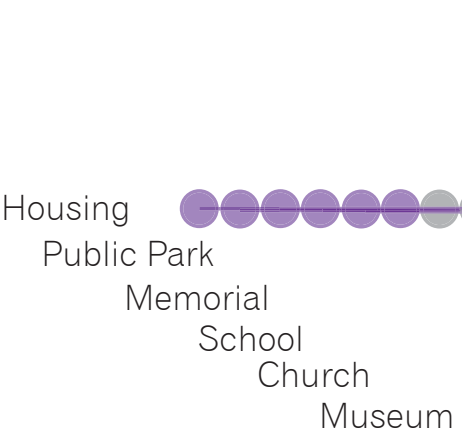

Memorial

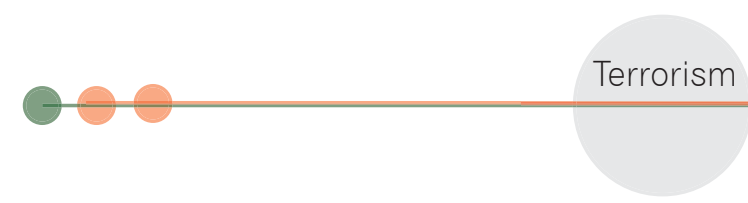

Mass Murder

.

\section{Public Park}

Housing

Museum

High impact events, where the death toll is high, the event has occupied the public imagination for an extended period of time, or the event has changed or defined society, were much harder to return to use or convert to new uses. There was only one new use amongst the high impact events and Staro Sajmiste is currently being developed into a museum and memorial to the holocaust. Many of these sites, even if returned to use, have been memorialized in some way, even just by a plaque ( eg. Mt. Carmel) through to the massive development (eg. Ground Zero). There were also far more razed sites in this category, or sites where the survival of the record has been severely compromised by partial demolition or abandonment. In the case of high impact events the sites were eventually associated with the victims and memorialised (or returned to use as a show of resistance) or with the perpetrators and actively shunned by the community.

The Bain House

Carandiru

David Grays Crib

Fritzl Basement

Maze Prison

Manzanar Camp

Mt. Carmel, Waco

Sandy Hook

Spandau Prison

West Murder House

Abu Gharib

Anlong Veng

Ayodhya Temple

Bhopal Chemical Plant

Jonestown

Pripyat

Columbine High School

Emanuel AME Church

London Underground

Simpson House

Utoya Island

Staro Sajmiste

Anne Frank House

ESMA

Robben Island

Sixth Floor Museum

Terezin Memorial

Tuol Sleng

Auschwitz-Birkenau

Choeung Ek

CTV Building

Genbaku Dome

Ground Zero

Oklahoma Federal 


\section{Feasibility}

The output of all of the data analysis is a step by step process for evaluating the feasibility of different sites of negative heritage as a component of time since event when considering an adaptive reuse of the site. The data suggests that the main things to consider when looking at the feasibility are:

- Survival of the record (was it razed, abandoned, returned to use);

- The building type (i.e. is it residential, commercial, a large scale public building);

- The time since the event; and

- The impact of the event on the surrounding community or society as a whole (as stated in the previous section this has a lot to do with the political and social conditions and the nature of the victims and perpetrators).

All of these considerations combined must be known when evaluating a site of negative heritage for the prospect of future development. There are an impossibly large combination of possibilities, on page 57 is an example of the evaluation process when proposing a new use for a particular type of site derived from the analysed data.

These evaluations could also consider location, (whether it be urban or rural), the presence or absence of vocal interest groups, the socio-economic circumstances of the victims or perpetrators, and the mechanisms of erasure used. Each of these had slight impacts on the outcome of the site.

Ultimately however this data analysis has determined four categories (ie. razed, abandoned, returned to use and new use) which can be used to determine the likelihood of redevelopment on a site of negative heritage and the possible timeline for this development. This analysis has determined that there are some sites that appear to be simply unusable due to the impact of the event and the survival of the record, however there were many more that, after an 'appropriate' amount of time had passed, can be developed, whether into a new use or returned to their original use. Depending on the impact of the event these uses may need to acknowledge their negative history, while others can get away with ignoring it, the new use able to co-exist with each individual person's knowledge of the negative event.

However, this data analysis does not address how negative heritage should be treated on a site when a new use is proposed. The mechanisms of erasure introduced in tables 12 and 13 are a way to begin to look at this and an evaluation of what mechanisms are appropriate on a certain site will be experimented with as a part of the design process. 


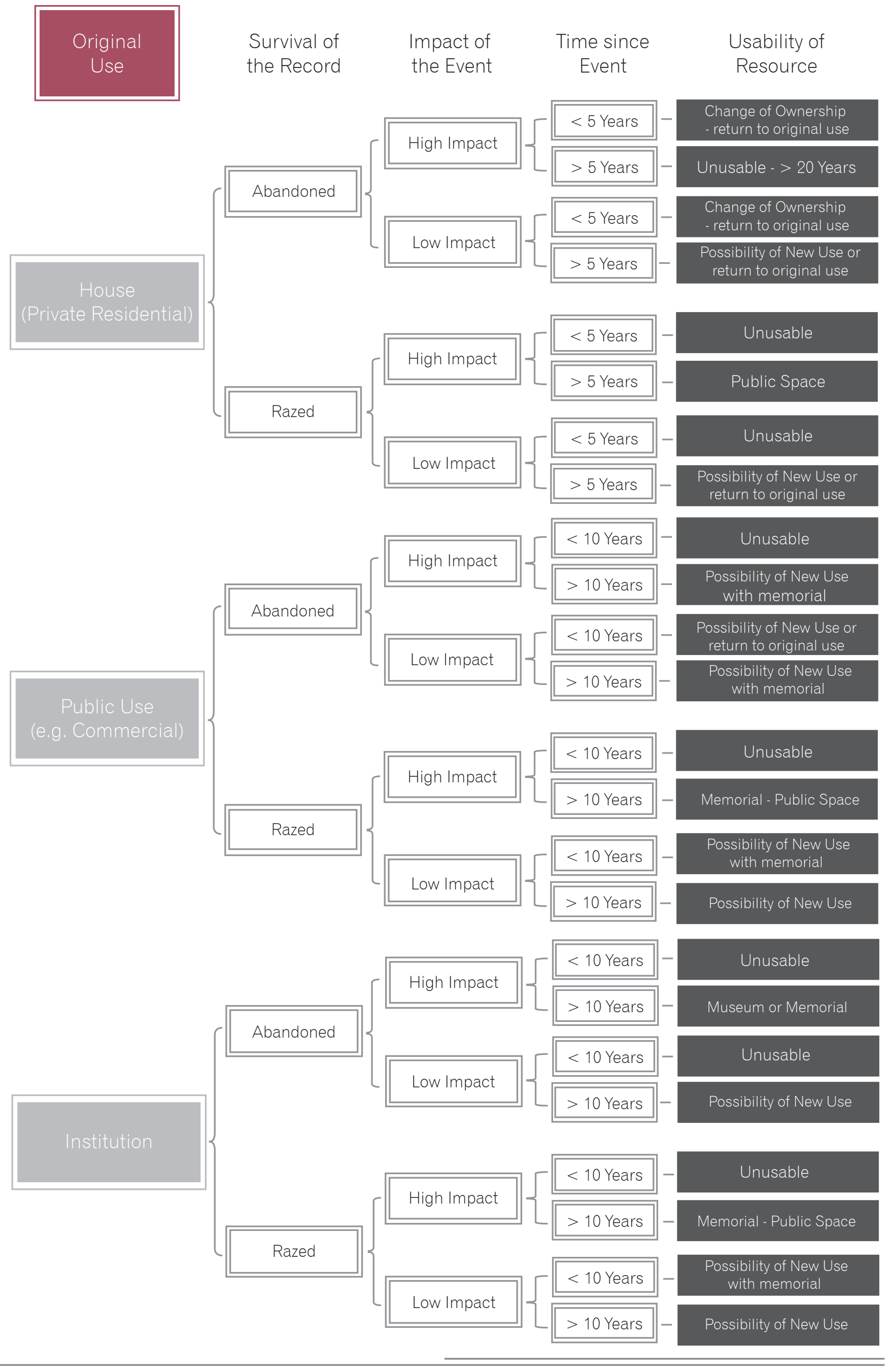





\section{Design Process}

The case study analysis created six distinct categories, defined by their treatment of negative memory, within which patterns can be drawn, namely: building type, location, event, socio-economic circumstance, political connotations and the collective memory of various interest groups and their final outcomes. It confirms many of the findings from the literature review and expands upon them. Importantly these categories set up a system for evaluating the likely development of various sites and determining timelines for reuse.

However this case study analysis does not address the key motivation of this thesis, which is to determine how negative heritage can be mediated, referenced and respected on a site when undergoing an adaptive reuse. In this chapter the case study analysis is used to formulate a design process to address this. The process (see p60) uses the data analysis to identify when a site is likely to be developed and create a reuse timeline. It then creates a process for testing and layering different mechanisms for erasing and integrating the negative heritage of a site into the new use, using the original data set as a reference point to evaluate which mechanisms are appropriate on a given site'1.

This chapter outlines an initial draft process and then tests it using the former Kimberley Centre site in Levin². This process uses an individualized, negative heritage specific form of site analysis that focuses on the site history, current identity and interest groups to determine the feasibility and reuse timeline of the site. It then reviews the physical remnants of the site for traces of memory that may need to be erased, integrated or referenced in the development of an adaptive reuse. The use of a test case to experiment with the application of the data analysis allows the process to be further developed and refined, considering the changing nature of collective memory, social convention and the consequences that time has on memory.

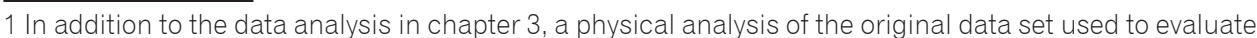
the appropriateness of mechanisms of erasure and an outline of what these mechanisms are can be found in Appendix B

2 The testing and further refining of the process by layering mechanisms to create an initial design can be found in chapter five. 



\section{Design Process}

Fig. 4: The design process can be broken up into three stages. Each stage is designed to act in a loop, where refinement can continually take place. It is influenced by a selection of varying criteria that can impact on each stage and therefore the entire process. Each stage will be broken down and explained using the Kimberley Centre as an exemplar in the coming two chapters. Stage One, the case study analysis and generation of mechanisms has already taken place in Chapter 3 but will be explained as a part of the process on p63. Stage Two, the site selection and analysis will be set out on p65 and then the rest of this chapter will run through this part of the process with the Kimberley Centre site. Stage Three, the testing and layering of mechanisms on the site with the integration of a new function will be carried out in Chapter Five.

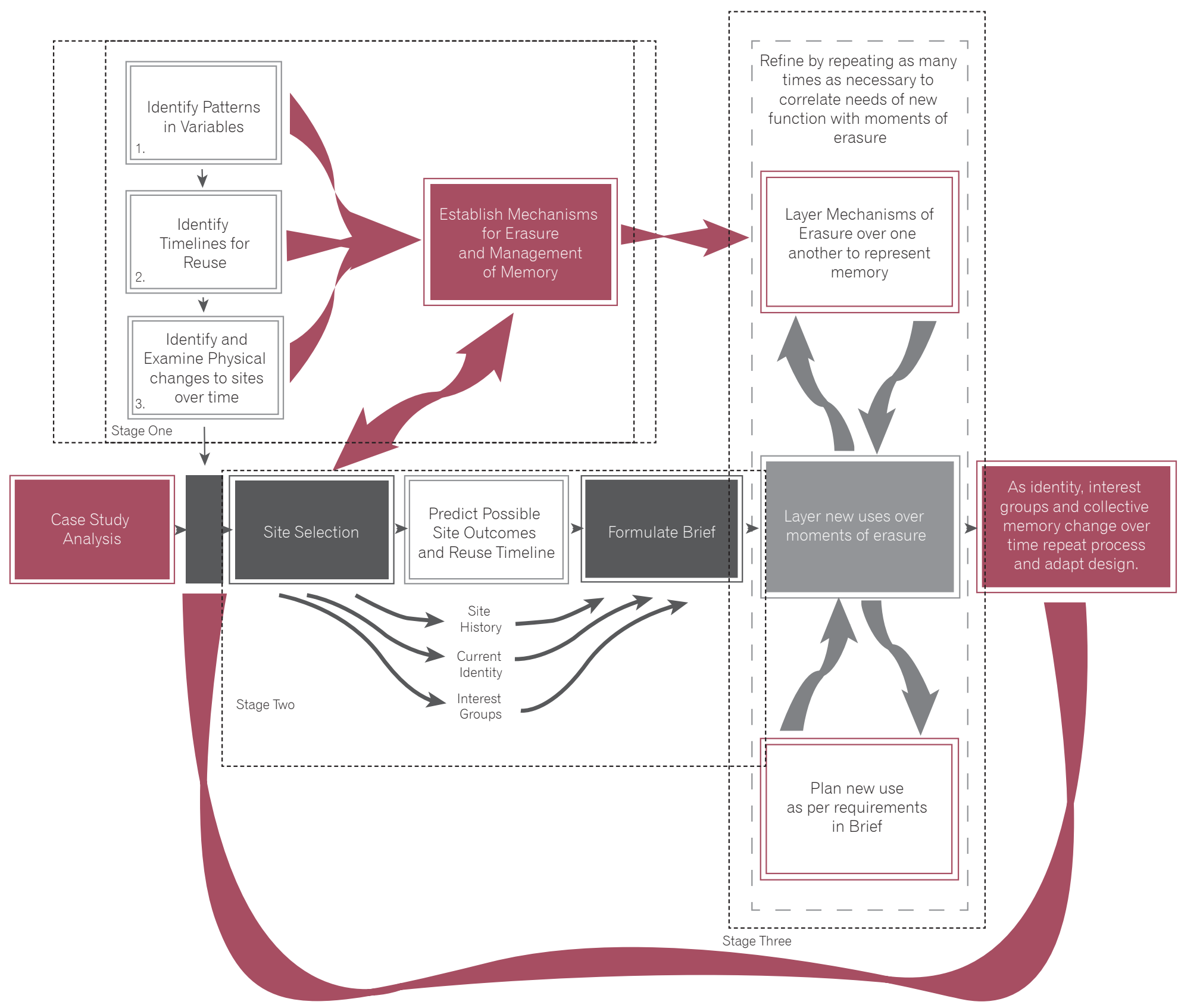





\section{Stage 1: Case Study Analysis}

The previous chapter lays out the case study analysis by looking at the patterns between building type, event and outcome that can then be used to determine the viability/unviability of a range of sites. This is vital data to be aware of when beginning the adaptive reuse process of any site. What the analysis also does is lay out initial mechanisms for the management and erasure of memory on a site. These mechanisms are laid out in tables 12 and 13

To identify these mechanisms a physical analysis of a range of sites was undertaken and can be found in Appendix B (p189). Erasure was an element of all the case studies whether they were razed or returned to use, the physical remnants of the building act as reminders of memory. The removal or manipulation of these reminders is an act of erasure that aims to either remove the place from the collective memory or change its perception to allow for an adaptive reuse.

Below is a more detailed view of stage one of the process, it shows the variable that will need to be evaluated in the categorisation and timeline analysis in stage teo once the site has been selected.
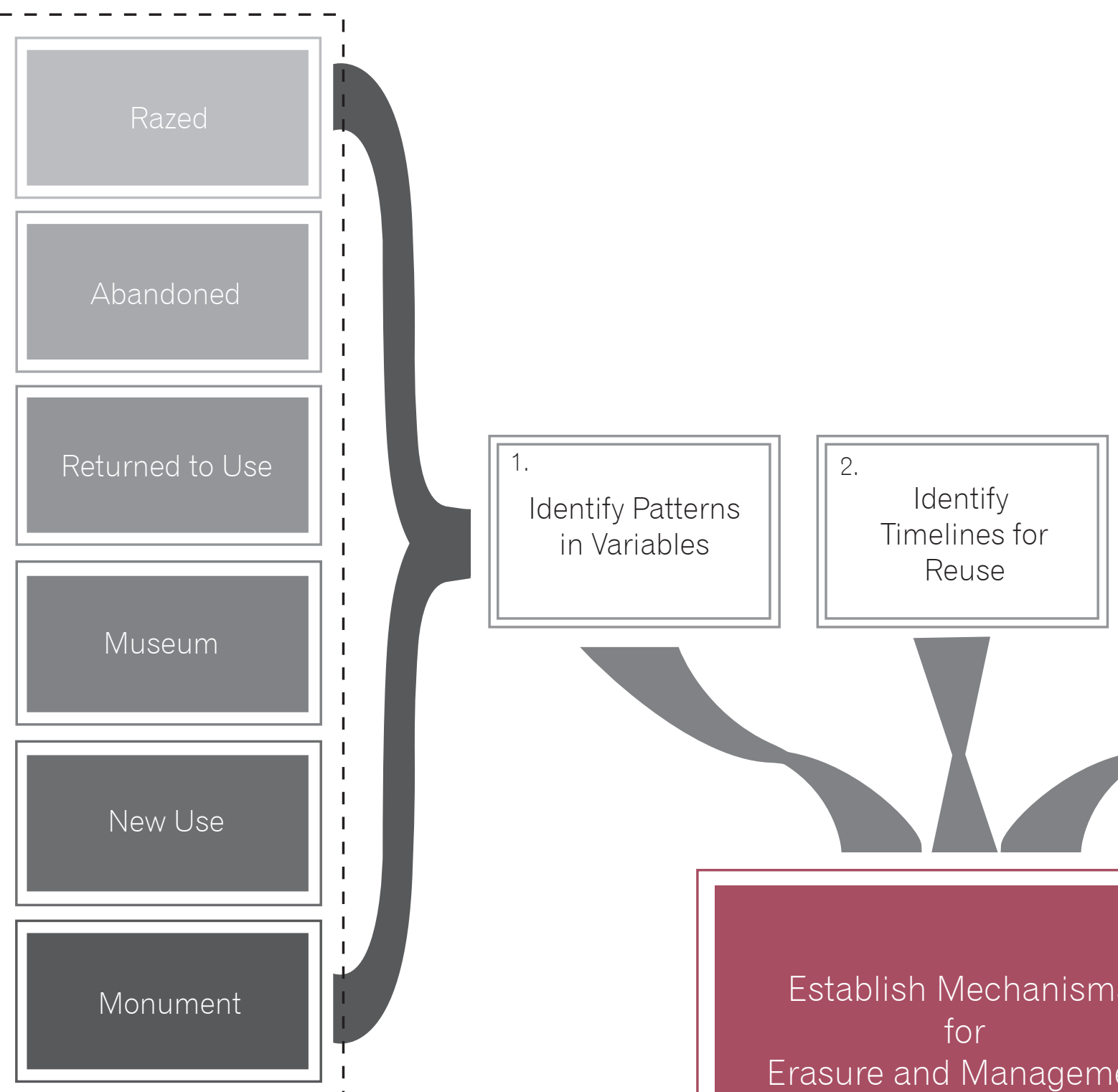

3. Identify \& Examine Physical changes to sites over time
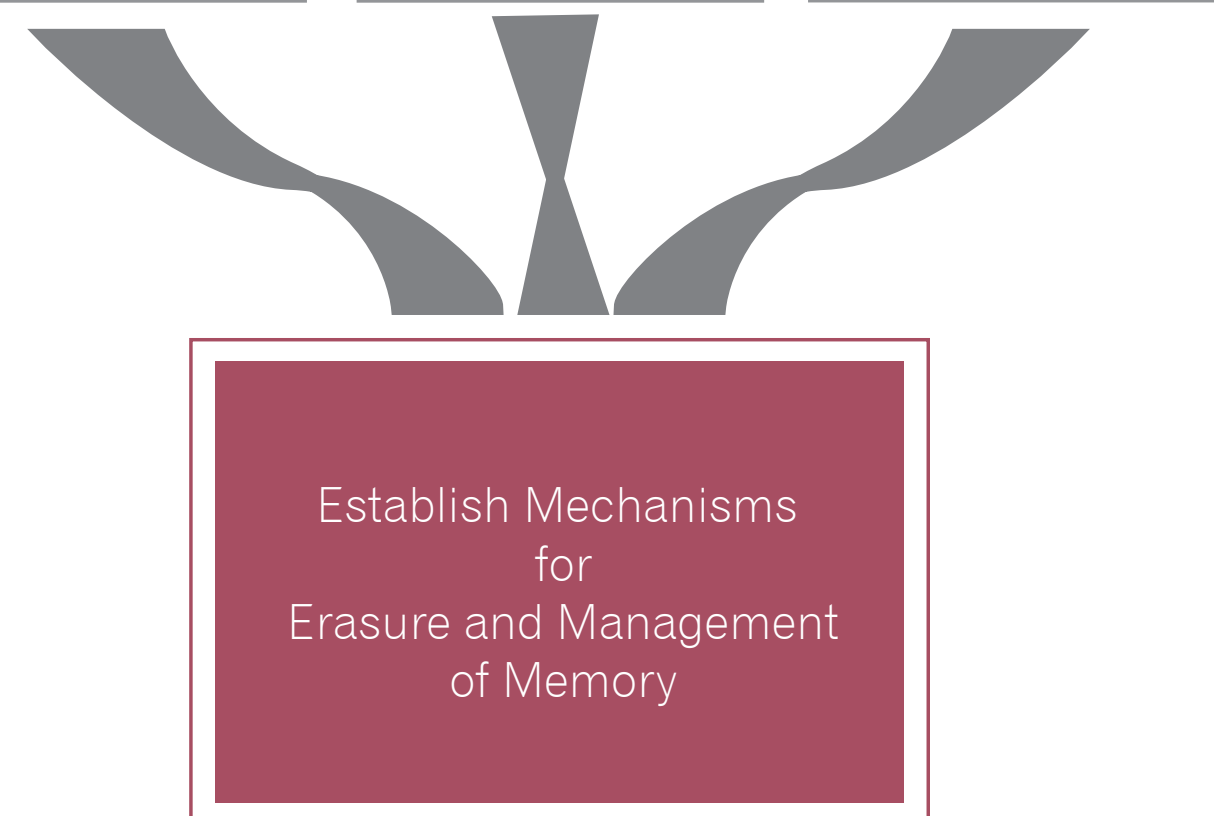



\section{Stage 2: Site Analysis}

Stage 2 takes the site history, current identity and interest groups of a site and evaluates them using the parameters determined by the case study analysis in stage one. It uses this information to evaluate the viability of the site for certain uses, formulate the brief and determine the appropriateness of various erasure mechanisms. By understanding the usability of a given site and the timeline in which it can be developed, the erasure mechanisms used on the site can be more specific. These can be tested simultaneously to developing the brief in order so that these mechanisms may influence the management of memory by the new use. The categorisation and timeline analysis is stage one of the process applied to the site and is shown separate explicitly in this diagram. (Note that the current identity and interest groups analysis has been combined on this diagram where it is separate on the design process diagram on p60).

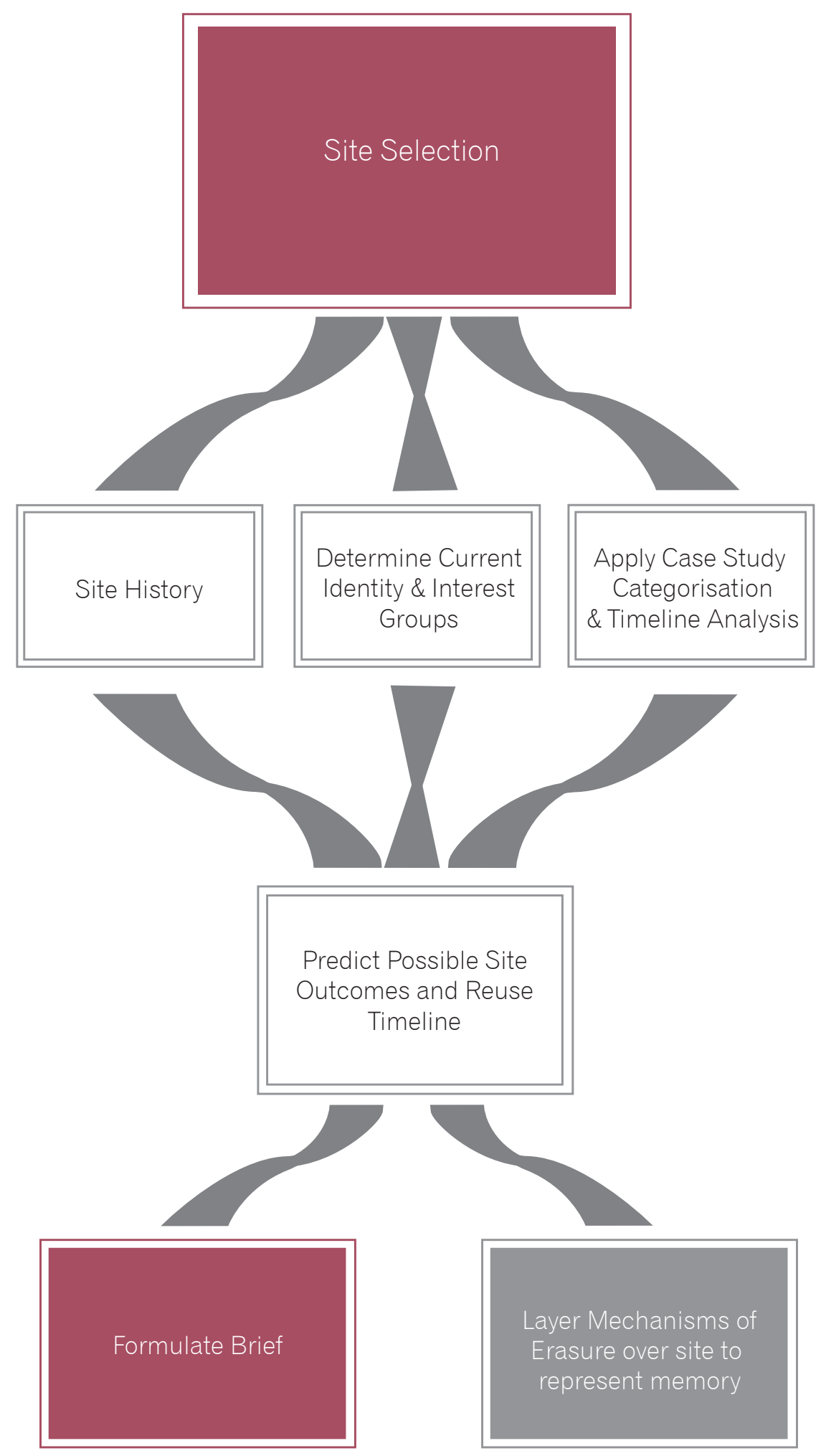





\section{Kimberley Centre}

'Systematic abuse is going beyond the notion of 'bad things being done by bad people' independent of the system, to a recognition that the system has operated in ways that has both provided the opportunity for abuse to occur, or for it to continue unchallenged. At a fundamental

level institutions are inherently abusive' - 2017 HRC Report on abuse in State Care

In 2017 the Human Rights Commission (HRC) released a report on the experiences of disabled children and adults in state care of which identified institutions as inherently abusive. On 1st February 2018 Prime Minister Jacinda Ardern and Minister for Children Tracey Martin announced that a three year Royal Commission of Inquiry would be launched to find out how and why abuse was able to take place in state care.

This wider context has identified institutions of state care as being particularly relevant and topical, consequently the Kimberley Centre site in Levin has been chosen as an experimental test site for refining this draft design process. The ongoing revelations and recognition of the events that took place in state care mean that the Kimberley site is an appropriate place for public reconciliation, an opportunity to reintegrate a forgotten and stigmatised site back into the public consciousness. The possible changing of public opinion about the site in the wake of this inquiry is also likely to test how adaptable the process is to a site changing over time both physically and in the collective memory 



\section{Site History}

The Kimberley Centre is located on a 14.8 hectare site south of Levin on State Highway 57, the main route from Wellington to Palmerston North. When it closed in 2006 the Kimberley Centre was the last remaining large institution of its type in New Zealand. At its height it housed 700 residents at various levels of intellectual disability as well as approximately 200 staff in its 60 buildings ${ }^{1}$. All of the buildings on the site are in various stages of dilapidation, they are all of a timber construction with a mixture of timber and brick facades. For much of its life the site has been invisible to the general public, hidden behind fences and thick shrubbery.

The western part of the site was originally bought by the Crown and developed as the Weraroa Boys Training Camp, (opened in 1906). The camp, 'the place where the naughty boys were' was shunned by the people of Levin, unseen and not talked about ${ }^{2}$. When the site was sequestered by the RNZAF in 1939 a massive five week building campaign was undertaken with most of the training camp buildings torn down and replaced with barracks and communal buildings of a timber construction ${ }^{3}$. With the war ending, the site was shuffled around government departments before it was decided that it was ideal for a North Island equivalent of Christchurch's Templeton Farm, an institution that separated mentally deficient children from other mental patients, or those displaying criminal deviance ${ }^{4}$. While the Levin Mental Deficiency Farm initially occupied the RNZAF buildings, it quickly outgrew them, the constantly overpopulated institution growing to 60 buildings by 1970 all of which were constructed of standard plans devised by the Ministry of Works 5 .

\footnotetext{
1 Galuszka, 2014, n.p.

2 Hunt, 2000, p. 9

3 Hunt, 2000, p. 11

4 Hunt, 2000, p. 2

5 Hunt, 2000, p. 47
}

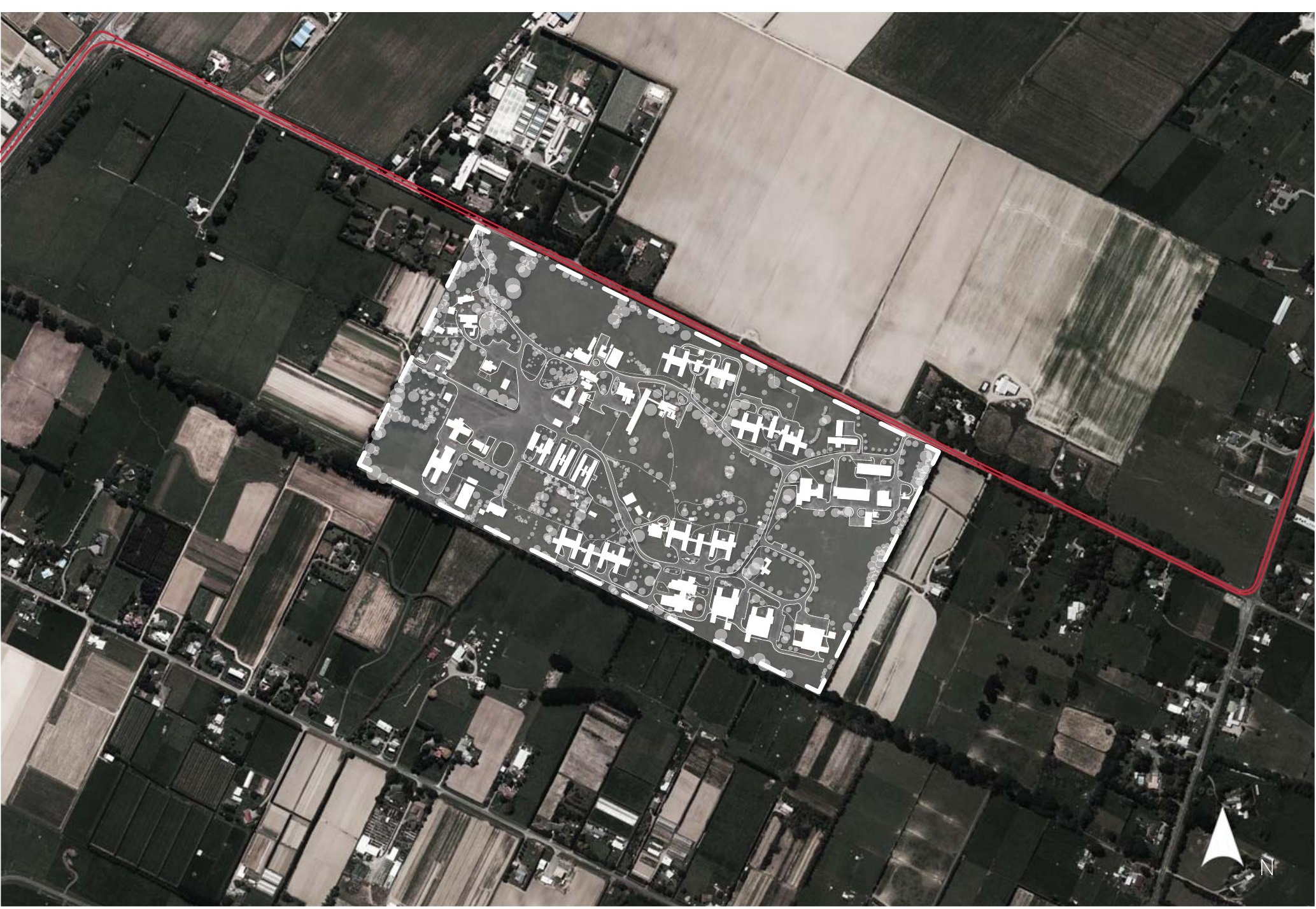




\section{Current Identity \& Interest Groups}

The site has been both shunned and embraced by the surrounding community over its 100 year life. When the mental deficiency farm was first proposed by the government in 1945, Levin's mayor, Herbet Phillips, travelled to Wellington to object to the plan. 50 years later, when a timeline was set up for the closure, of the centre Levin's mayor, Tom Robinson, travelled to Wellington with the aim of saving it ${ }^{6}$. Those running the institution made a concerted effort to engage with the surrounding community involving them in institution events and often bringing residents into Levin ${ }^{7}$. The closing of the centre put many locals out of work and changed the dynamic that mentally deficient children and adults had with the community8.

In 2017 the Human Rights Commission released a report on the experiences of disabled children and adults in state care, named 'Institutions are Places of Abuse'. This was in the wake of Elizabeth Stanley's 2016 book, The Road to Hell: State Violence against children in postwar New Zealand. Then opposition Justice spokesperson, Jacinda Ardern, said at the time 'that the state never fully acknowledged what happened to many in state care and that if Prime Minister John Key was not willing to issue a formal apology then Labour is committed to doing so'10. On 1st February 2018, now Prime Minister, Jacinda Ardern and Minister for Children, Tracey Martin announced that a three year Royal Commission of Inquiry would be launched to find out how and why abuse was able to take place in state care.

With the ongoing nature of these allegations the list of various groups interested in the Kimberley site expands. Beyond the current owner, Wayne Bishop, and his Speldhurst Estate retirement village, those who intend to occupy the new development, and the surrounding community, there is also the New Zealand government, which could be implicated in the current government inquiry as well as a national identity that may be shaken by its outcome. Whether the site becomes a focal point for this, and therefore a place for public reconciliation with a shameful past, is not yet known.

6 Hunt, 2000, p. 1

7 Hunt, 2000, p. 24

8 Newshub, 'Mixed Feelings from Residents over Kimberley Centre Closure' 2008, n.p.

9 Mirfin Veitch \& Conder, 2017, p. 2

10 Ardern, 2016, n.p.

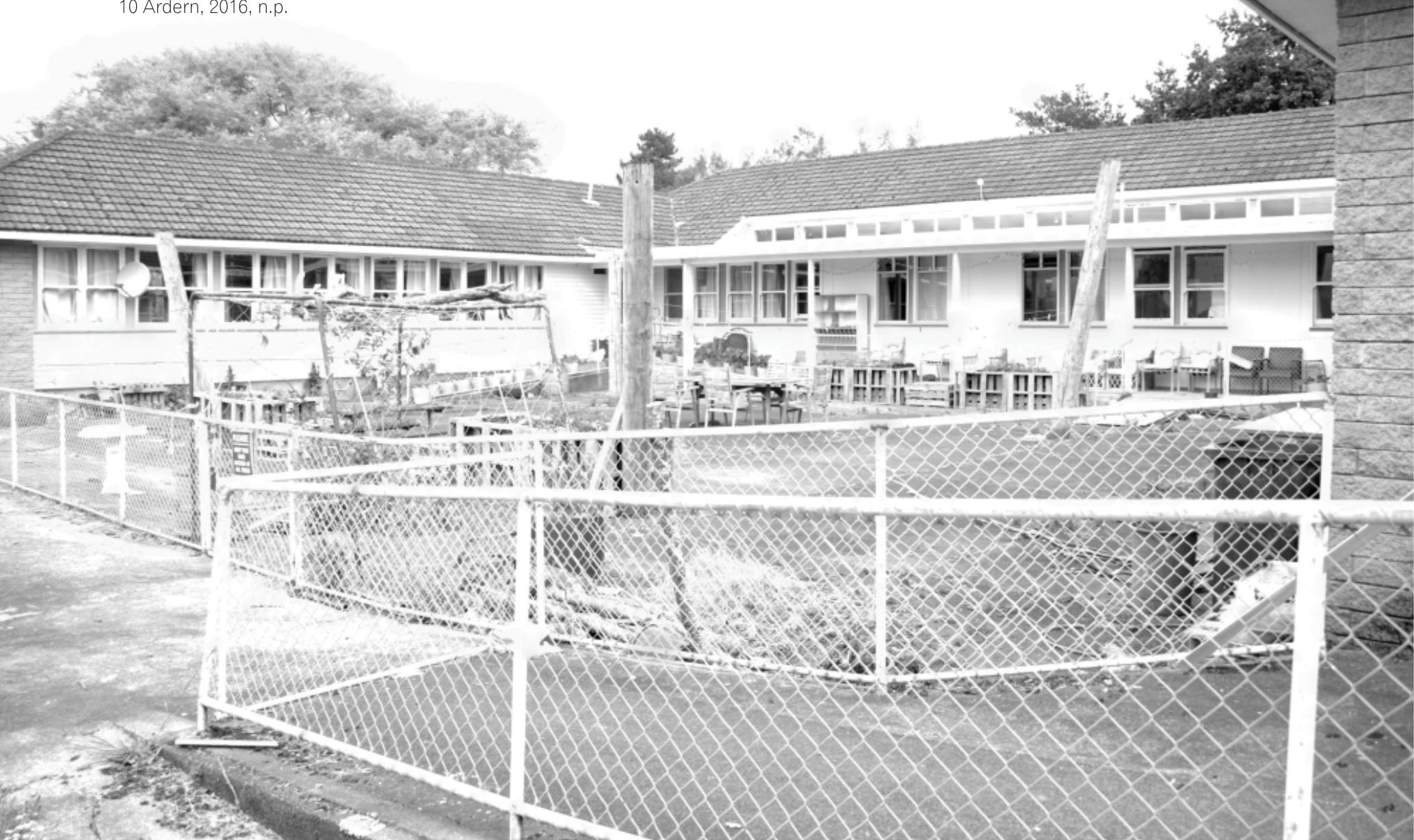




\section{Kimberley Centre Category Analysis}

\begin{tabular}{|c|c|}
\hline Building Type & Institutional Building \\
\hline Building Style & NZ Domestic State Architecture \\
\hline Built When & 1939-1972 \\
\hline Place & New Zealand \\
\hline Witness To & Confinement / Systematic Abuse \\
\hline When & $1945-2006$ \\
\hline Scale of Event & $\begin{array}{l}\text { Currently Unknown - As People continue to come forward the scale will become more } \\
\text { clear }\end{array}$ \\
\hline Abandoned When & 2006 \\
\hline Reason for Abandonement & Change in Government Policy \\
\hline Time to Demolish & 11 Years (so far about half the site demolished in 2017) \\
\hline How was Destroyed & Partial Arson / Demolition \\
\hline Demolished by & Arsonists / Wayne Bishop and his Speldhurst development company \\
\hline Time before Reused & $\begin{array}{c}14 \text { Years to be reused as Speldhurst Estate (Final Use), however after initial abandonment } \\
\text { many buildings were leased to various interested community groups who also provided } \\
\text { upkeep of the dilapidated structures during the sale process }\end{array}$ \\
\hline Reused & $2006-2017$ / $2016-$ \\
\hline Temporary Uses & $\begin{array}{c}\text { Riding for the Disabled, Levin Speedway Club, Levin Bowling Club, Tsunami Radio, Paint } \\
\text { Balling, Business and Medical Support Services }\end{array}$ \\
\hline New Use & Speldhurst Country Estate (Lifestyle Retirement Village) \\
\hline Current Owner & Developer and City Councillor Wayne Bishop \\
\hline Socio-Economic Class & - \\
\hline Urban Area & Rural \\
\hline Political Circumstances & $\begin{array}{l}\text { The abuse having taken place within a government institution means it has an inherent } \\
\text { political component, as any responsibility or apology in the coming years will have to } \\
\text { come from the sitting government. }\end{array}$ \\
\hline Changes to Building Envelope & $\begin{array}{c}\text { Some buildings have been entirely demolished. Others are under lease, buildings are } \\
\text { soon to be demolished so upkeep is not a priority }\end{array}$ \\
\hline
\end{tabular}

In 2017 the Kimberley Centre site is not static. Due to the size of the site and the process of development. The site could arguably lie in three of the categories that I established in my research.

The developer, Wayne Bishop, is progressively demolishing the site to make way for his new development, rather than developing the entire site at once, and so continues to lease the available buildings ${ }^{11}$. This means that some buildings have been demolished, and new buildings have taken their place, while others, which are no longer fit for use they are so dilapidated, have been abandoned, and those that can accommodate a new use are being reused.

Much of the site was residential in nature and has a domestic appearance. When residential properties are violated they are typically harder to develop and extremely unlikely to be returned to residential unless a long period of time has passed or the property has been significantly altered. There is also the possibility that these areas, though currently being developed, may in the future become less viable due to continuing revelations resulting from the Royal Commission of Inquiry.

This is a site in flux between its old and new use. Eventually it will be entirely demolished, any remnant of what was known as the Kimberley Centre removed from the site and the Speldhurst estate taking its place. What may change this projection is if sufficient public recognition is bought to the abuses of the site, calls may be made for a memorial or remnant of the site to remain as recognition of this painful past. 


\section{Site Event Timeline}

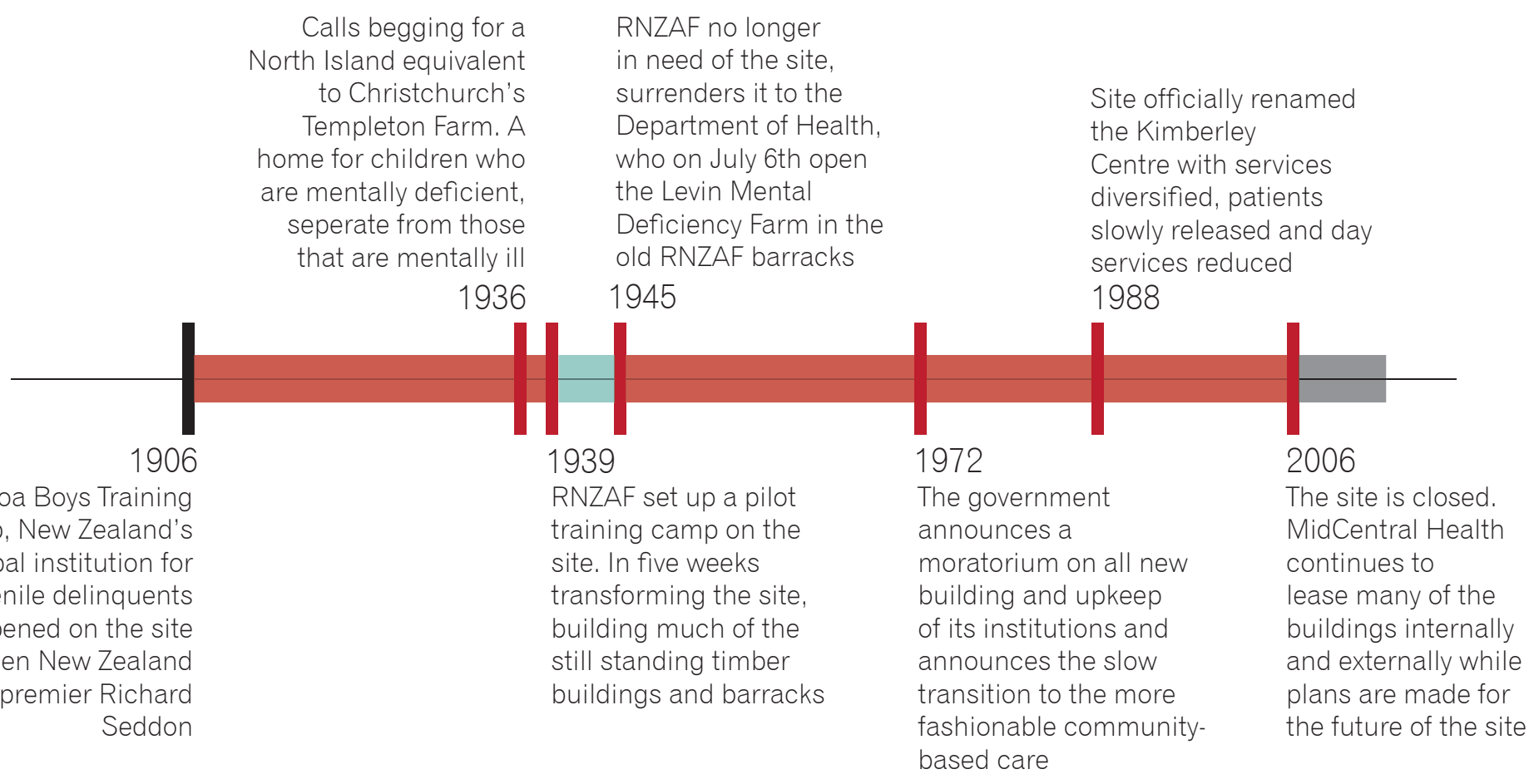

\section{Future Projections}

After a lengthy transfer process, the site was sold to Horowhenua developer Wayne Bishop who intends to develop the site into a 500 home lifestyle retirement village

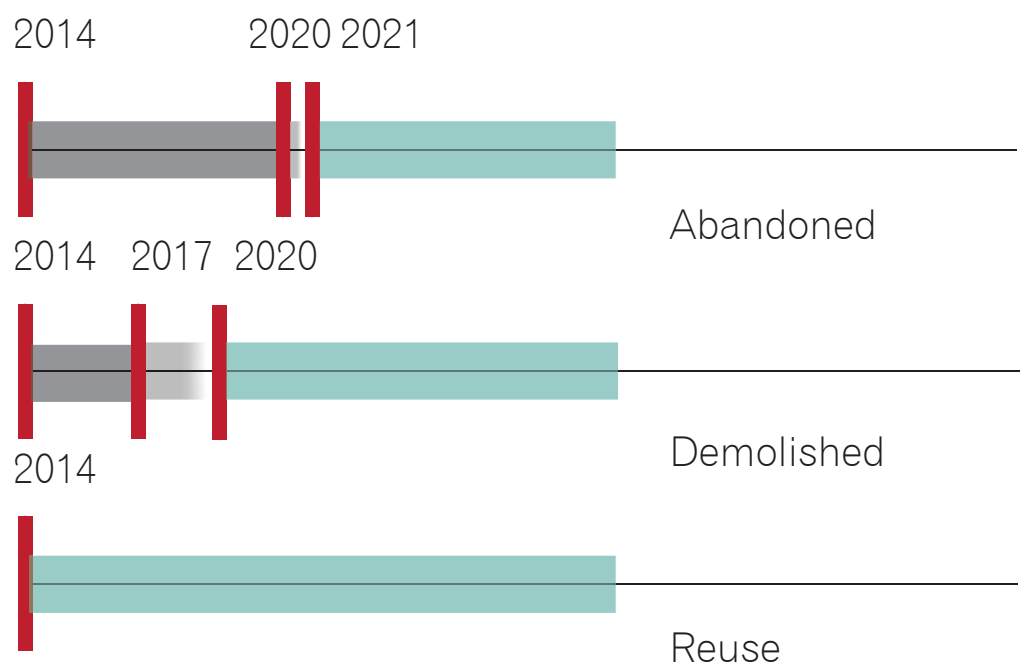

Parts of the site have already been demolished and much of the rest will be demolished by 2020. Over the next 20 years, Bishop intends to build 500 homes on the 14.8 hectare site. This will see the site completely reused, however not recognisable as the former Kimberley Centre. Much of the site will have been abandoned for a large period of time by the time it is fully demolished. By this point the Kimberley buildings will have become completely uninhabitable as many of these buildings are already becoming ruins, unsalvageable for reuse. The buildings that continue to be used are those in the best condition and despite the Speldhurst plan could remain in their current use. Their use increases the likelihood of the buildings survival. 


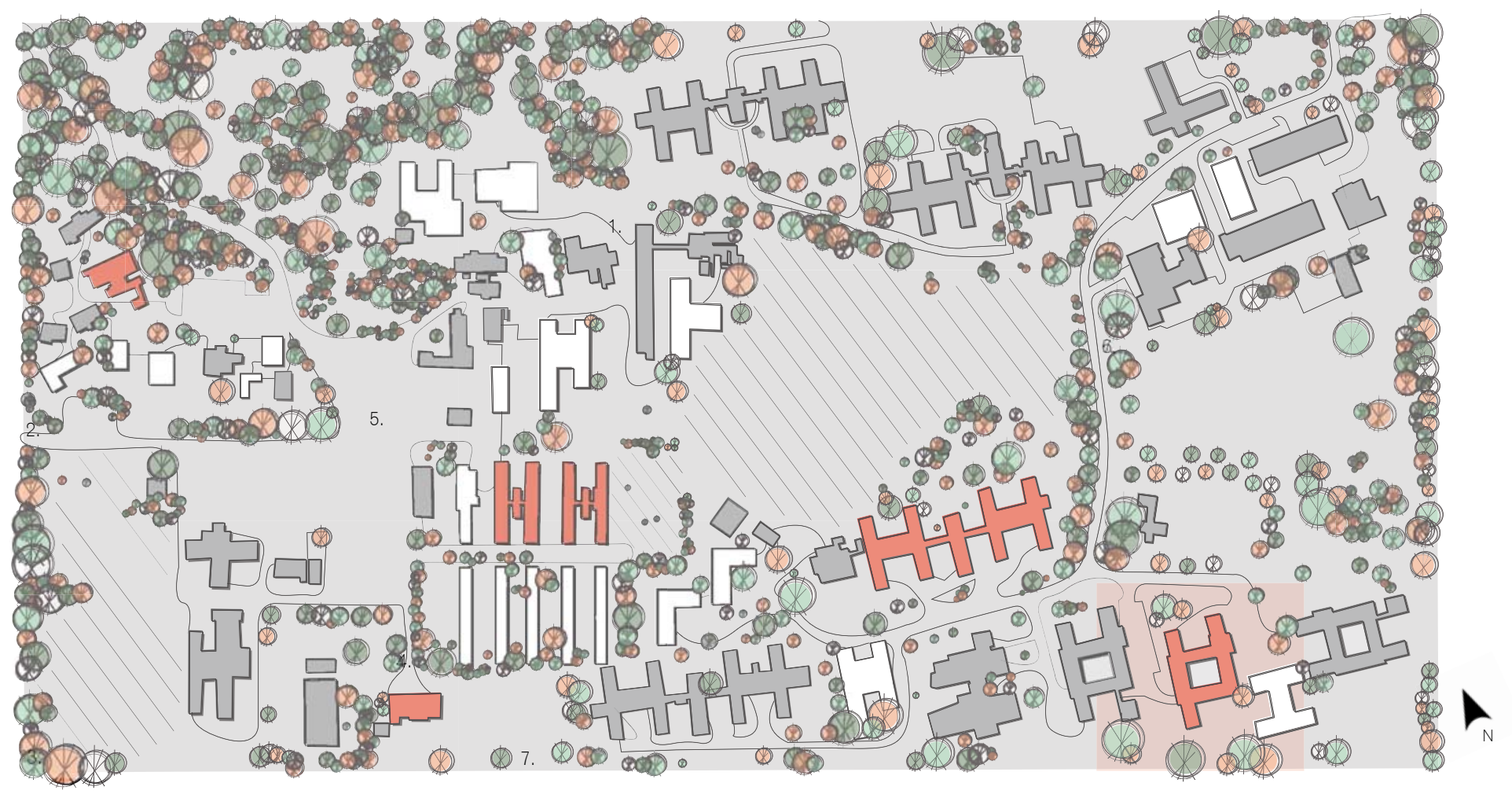

Buildings identified with negative memory attached

\section{Master Planning}

Integrating the site into the surrounding context using urban planning techniques was identified as a relevant part of the adaptive reuse of certain sites, particularly of Kimberley's size and nature during the physical analysis which can be found in Appendix B.

The master planning proposed a mixed programme, with new buildings and large green spaces, similar to approaches used at Staro Sajmiste and the former Lorton Workhouse, to draw people onto the site. However, a generic master planning approach ignores the identity and associated collective memory inherent to the site, and the preconceptions and reactions of the public at a national, and local level, in a small town where almost everyone will have a personal relationship or opinion of the site. Rather than continuing to develop this further, I identified buildings on the site of which had been witness to some of its most cruel and tragic events based on the public revelations and which could be developed in the future, within the scope of this thesis, in order to experiment with erasure techniques and and the connotations of reuse at a smaller scale. 


\section{Ward 7}

\section{Floor Plan}

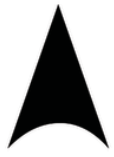

N
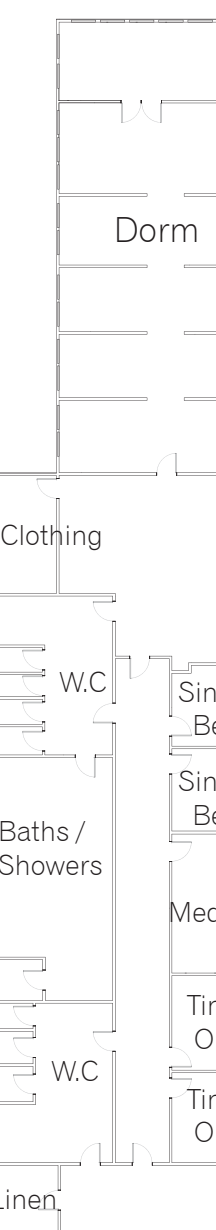

Ramp

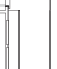

rm

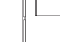

4

$$
\text { Bed }
$$

Time

Out

Time

Out

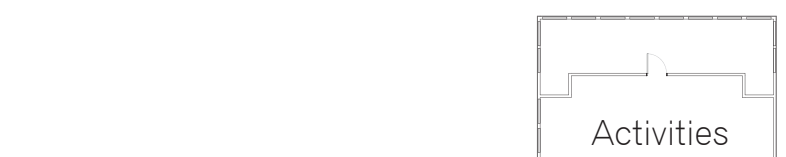

Dayroom

W.C.
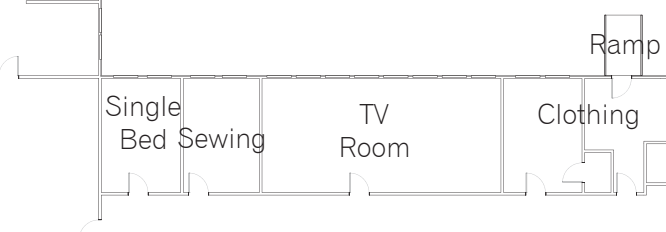

? Clothing
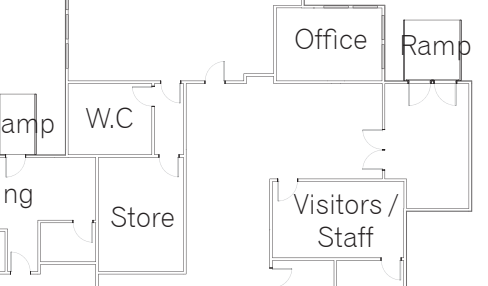

? W.C

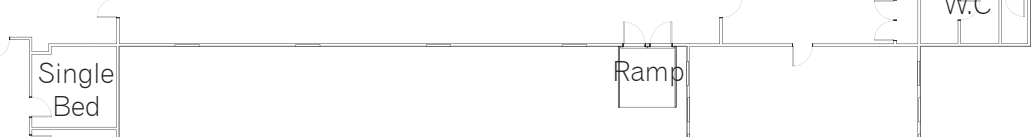

Dining

Dock

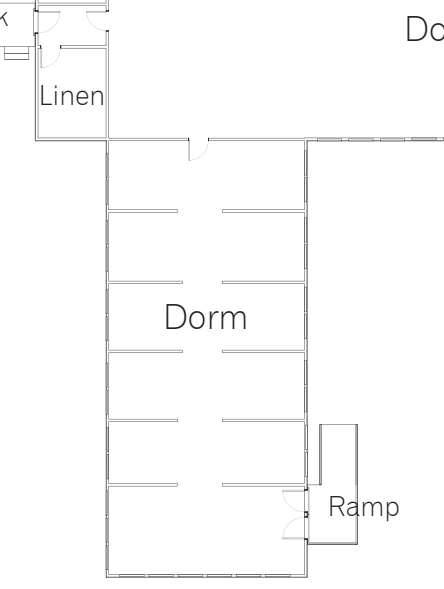

Dorm

most often in the allegations made in the 2017 HRC report and therefore provides a space where reconciliation and reintegration through the outpatient clinic can be staged.

The building is single storey and was constructed in the mid1960s based on standard Ministry of Works plans. Three buildings all of the same layout were built at the time. The building is in relatively good condition and has a fairly basic easily replicable plan that includes dorms, day rooms and various facilities. It is of lightweight timber construction, on timber piles with timber weatherboard facade. The building had a residential function and those housed there would have been confined for the safety of themselves and others.

The building is situated at the back of the site with both service

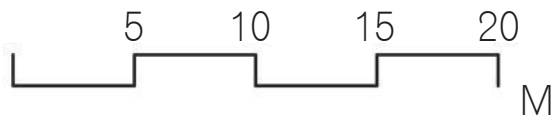
very little landscaping aside from the boundary tree line. 


\section{Ward 7 Category Analysis}

\begin{tabular}{|c|c|}
\hline Building Type & Institutional Building \\
\hline Building Style & NZ Domestic State Architecture \\
\hline Built When & 1966 \\
\hline Place & New Zealand \\
\hline Witness To & Confinement / Systematic Abuse \\
\hline When & $1966-1996$ \\
\hline Scale of Event & $\begin{array}{l}\text { Currently Unknown - As People continue to come forward the scale will become more } \\
\text { clear }\end{array}$ \\
\hline Abandoned When & 2006 \\
\hline Reason for Abandonement & $\begin{array}{c}\text { Closure of site due to turning away from institutional care to community care leaving } \\
\text { buildings redundant and no longer fit for use }\end{array}$ \\
\hline Current Owner & Developer and City Councillor Wayne Bishop \\
\hline Urban Area & Rural \\
\hline Political Circumstances & $\begin{array}{c}\text { The abuse took place within a government institution giving it an inherent political } \\
\text { component, as any responsibility or apology in the coming years will have to come from } \\
\text { the sitting government. }\end{array}$ \\
\hline Redevelopment & Building to be developed like much of the rest of \\
\hline Marker of Difficult History & NA \\
\hline
\end{tabular}
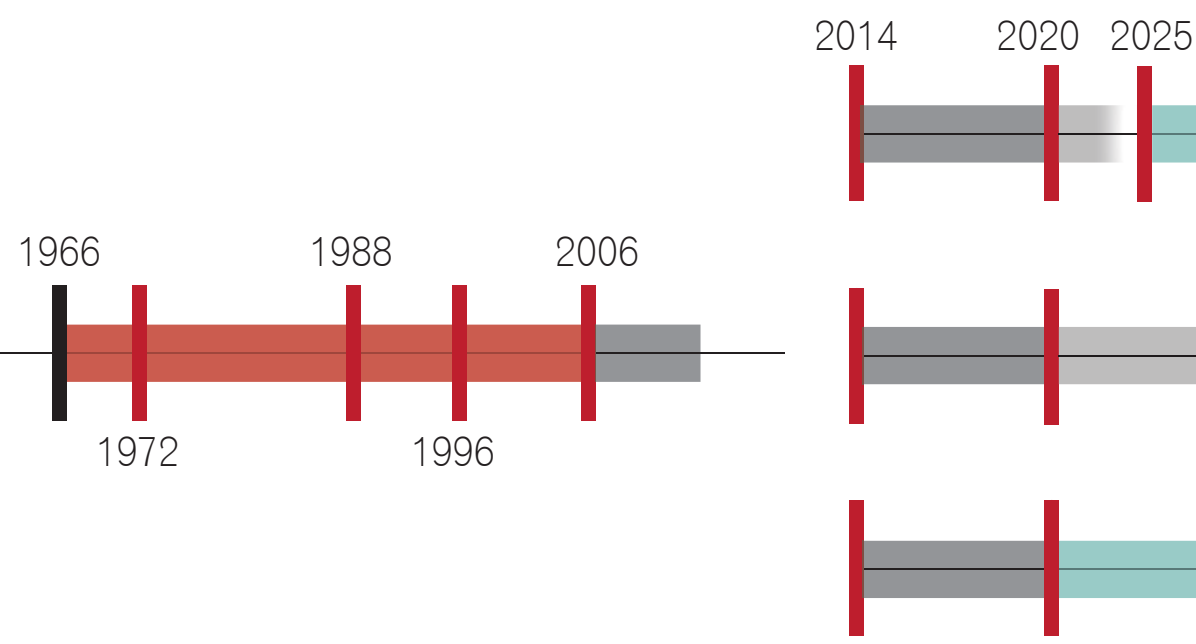

The Ward 7 Building, built during the largest building campaign on the site in the 1960s and later designated as the dangerous behaviour ward, has been largely out of use since the mid-1990s, when the centre reduced its services and began transitioning its residents to community based care. Many of the stories now being revealed about the centre took place in and around Ward 7, which had a notorious reputation among staff and residents alike. The building is yet to be demolished, and is likely one of the last to be demolished, due to its position on the east end of the site (Bishop's development is being constructed west to east on the site). If the building was to remain, however, to invoke memory of the site's dark past, it seems conceivable that the building would be reused. This is unlikely while revelations continue and reports continue to be written. The building would not be conceivably used before 2020 and in the meantime may continue to deteriorate. 


\section{'The Kimberley Cringe'}

'See I have been here over ten years all up and these people were brought up in fear, when you look at the things that went on in this place it was horrific. They were cruel, they were very cruel people. We had men out in the courtyard here, do you know how they got showered? With the fire hoses and they used to take them out there to beat them. If you rush up to one of these people quickly, they will cower and that's when they have had hidings at a very, very young age The Kimberley Cringe that's what they call it'1

There are parts of the building, explicitly referenced in the HRC reports, stories and revelations, which clearly invoke stronger memories of trauma than others. Those areas are identified here in red and will be the focus of the experimentation of erasure techniques in the next chapter.

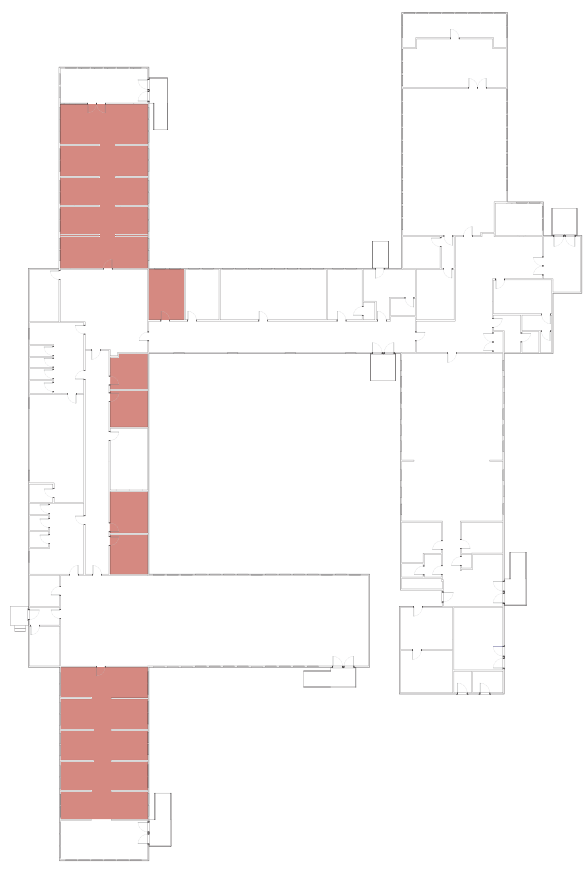

Fig. 13.1 - The dorms designed into solitary bunks for the purpose of curative care were most often used solely for punishment. Residents could often be left for days and in this time would be prone to hurting themselves ${ }^{2}$.
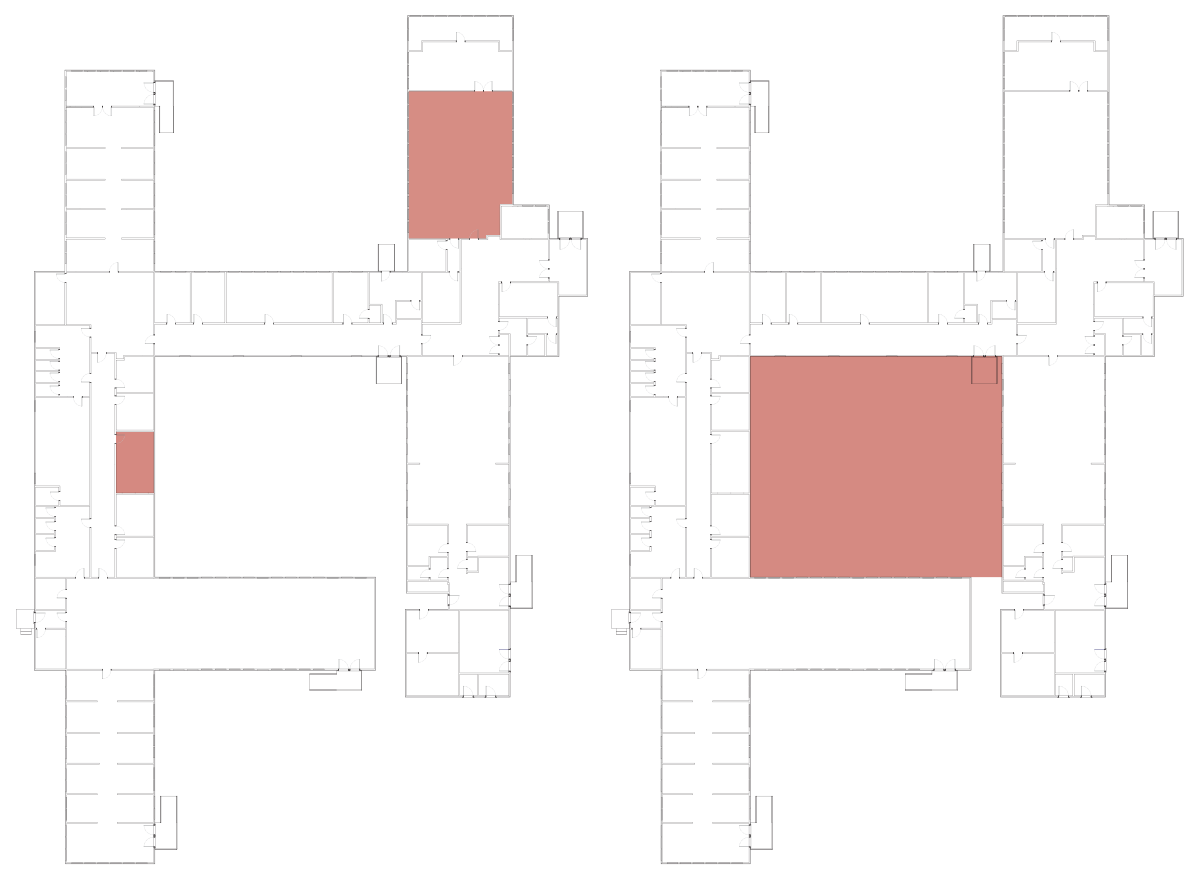

Fig. 13.2 - Residents were left in the Fig. 13.3 - Residents were showered day rooms with nothing to do, often using high pressure hoses in the all day, with limited supervision. central court yard which was largely The younger children managed to invisible to other residents ${ }^{3}$. entertain themselves but the older kids tended to lash out at each other often physically abusing one another just for something to do. Ward 7 is the only ward with a specialised medical room within the ward to deal with these types of injuries and behaviour.

In this chapter, a thorough site analysis, has allowed initially the entire Kimberley Centre site, and subsequently just Ward 7 to be evaluated against the data laid out in the case study analysis to generate a series of possible reuse timelines. The identification of negative memory on the site is the key driver of stage 3 of the process, the layering of mechanisms to integrate the memory and the new use. This site analysis has drawn on the site history, current identity, interest groups and site data to generate possible outcomes of the site as well as an understanding of its physical layout. It has also identified some issues with the initial draft process. Due to the complexity of the Kimberley Centre site, its varying physical outcomes and unsettled public identity, this process cannot be applied to the entire site as a whole. It may be that for this process to be applied to large complex sites such as Kimberley, the site will need to be broken down into different identities and physical outcomes and each part put through the process separately in order to coherently and respectfully attend to the negative memory attached to the site. 



\section{Test Design}

The draft design process aims to create a process for the adaptive reuse of buildings of negative heritage that mediates and respects the negative heritage of the site. Stages 1 and 2 of this process, as explained and then tested in the previous chapter, created a data set, that was developed to inform stage 3 of the design process.

This chapter tests stage 3 of the design process on Ward 7 of the Kimberley Centre site. It uses the current identity, interest groups and physical analysis to develop a brief for the site that introduces a use that will remediate the site in the collective memory. It then layers erasure techniques over the spatial and environmental requirements of this new use in order to test different variations of how the physical articulation of negative memory can influence the design.

The erasure techniques, taken from the case studies, are used to experiment with how memory can change the appearance of the building, by removing or changing the parts of the building where the memory of the trauma is at its height1. For the Ward 7 test case, demolition, burning and abandonment are experimented with as these are mechanisms that have already been used elsewhere on the site. Re-surfacing and entombment have also been investigated. These techniques are then evaluated against the case study data. Whether or not the techniques make the building more able to be developed is contingent on whether or not the erasure techniques make the building more evocative. This test will allow the evaluation of the mechanisms in relation to the Kimberley Centre site, as well as their application to other sites in general, and their effectiveness at fulfilling the aims of the process to remediate memory on a site in order to make it more available for reuse. 



\section{Stage 3: Design Test}

Stage 3, uses the data collected in stage 2 to formulate a brief for the adaptive reuse of the site. The brief is developed based on the site projections and reuse timeline designated by the case study analysis and site analysis of stages $1 \& 2$. This information is also used to judge the appropriateness of different mechanisms on the specific site.

The design test phase then layers the different erasure mechanisms over the spatial and environmental requirements of the new use, in order to understand how these may work to incorporate elements of the negative memory into the design of the new use.

This part of the process is designed to be repeated as many times as required, incorporating changes that occur over time to refine the design as much as possible.

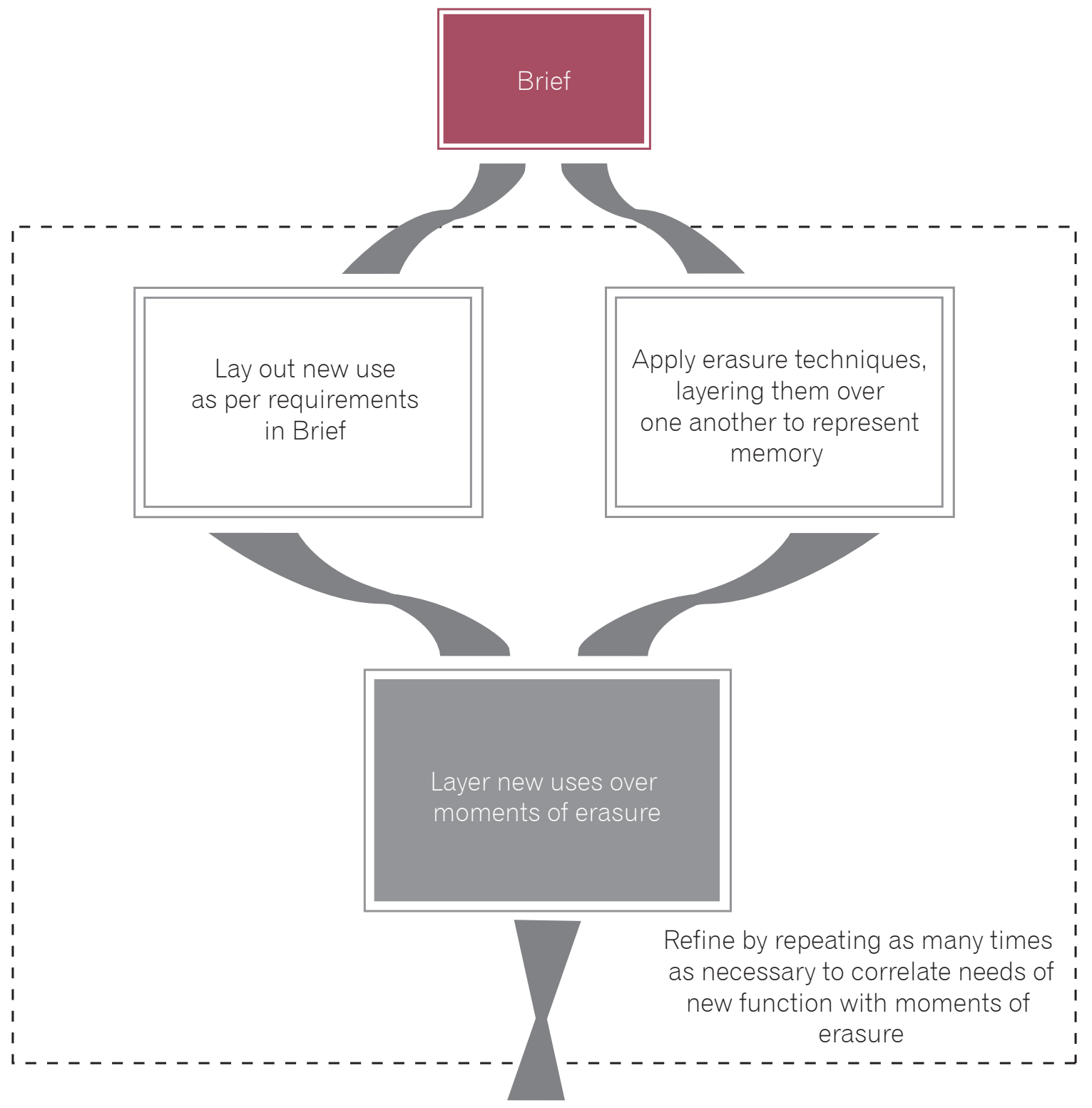

As identity, interest

groups and collective

memory change over

time repeat process

and adapt design. 



\section{Design Brief}

The design brief for Ward 7 of the Kimberley Centre responds to its current identity and interest groups surrounding the site and considering possible ways to remediate the building in the collective memory.

In The Road to Hell, Elizabeth Stanley documents the different consequences for children who were victims of state abuse. 81\% of abuse survivors suffered from psychological disorders including anxiety, mood or personality disorders, alcohol or substance abuse, depression, post-traumatic stress disorder and demonstrated severely disrupted mental functioning. These disorders often led to emotional fallout and difficulty in relationships.

Offering outpatient clinical facilities on the site is a way to remediate its negative history and limit its potency. Ward 7, the former dangerous behaviour ward, offers an ideal setting for this clinic in a familiar building amongst an established community.

The brief is to incorporate four clinics into the building that are distinct from each other and are legible in plan. The clinics will be for: Sleep Therapy, Substance Abuse, Depression \& Anxiety and Personality and Mood Disorders. In 'Stressed Spaces: Mental Health and Architecture' the authors look at a range of research and case studies in order to determine the effect of architectural design on the users of mental health facilities. Their findings have been used to define the scope of this brief'2.

\section{Sleep Therapy Clinic}

A sleep therapy clinic requires limited light and reduced noise. The space should be small and easily legible while being a calm and relaxing space. The clinic requires a waiting room and transition space from inside to outside as well as clinical and office space, with possible shared bathroom and reception space ${ }^{13}$.

\section{Substance Abuse Clinic}

Substance Abuse clinics require group and individual therapy rooms with the possibility of 24 hour response short stay units for the purpose of rehabilitation. The area should be able to be broken up and have a complexity that can distract patients and provide comfort and freedom of choice ${ }^{14}$.

\section{Depression \& Anxiety Counselling Centre}

The counselling centre will need to be positioned within the building so that it gets plenty of natural light and reduced noise while offering a reception, waiting rooms, and clinical space that is flexible and multipurpose. It is important to allow freedom and comfort in the counselling services that keeps a connection with the outside ${ }^{15}$.

\section{Personality \& Mood Disorder Treatment Centre}

Disorder centres need natural light and a strong connection to the outside with small waiting rooms that limit the amount of people in shared spaces. The plan must be familiar, rigid and unambiguous and reduce noise and the ability for echoes. The clinic must be separated and each function must be distinct ${ }^{16}$.

The clinics will share staff, storage and utility facilities in order to keep the building compact and provide coherency between each individual clinic. The building should be legible, both inside and out, with the difference in functions easily discerned.

As part of the design process the aim will be to layer the new functions over those of the former dangerous behaviour ward, considering the former negative memory as a central part of the design. The first part will be to identify the negative memory associated with the building and the parts of the building where this memory is most potent in order to understand where erasure will need to take place. These parts of the building can then become central components to the design and influence the layout of the new function.

The process acts in a feedback loop, so that this memory influences the adaptive reuse but doesn't confront the users with the negative memory. Instead it subverts it, in order to make the building viable for a new use. 


\section{Abandonment}

The physical breaking down of the building over time through neglect
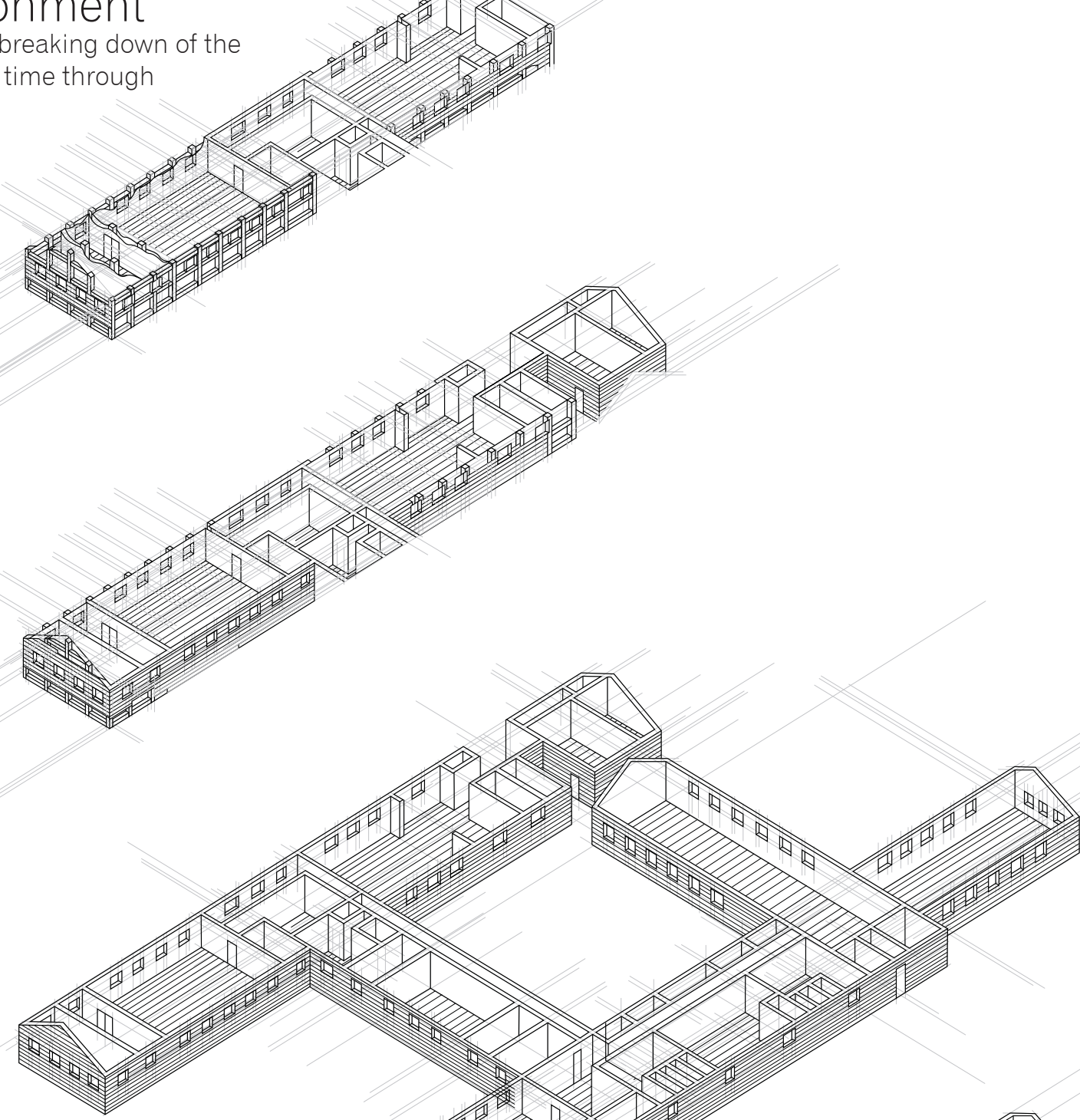

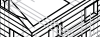
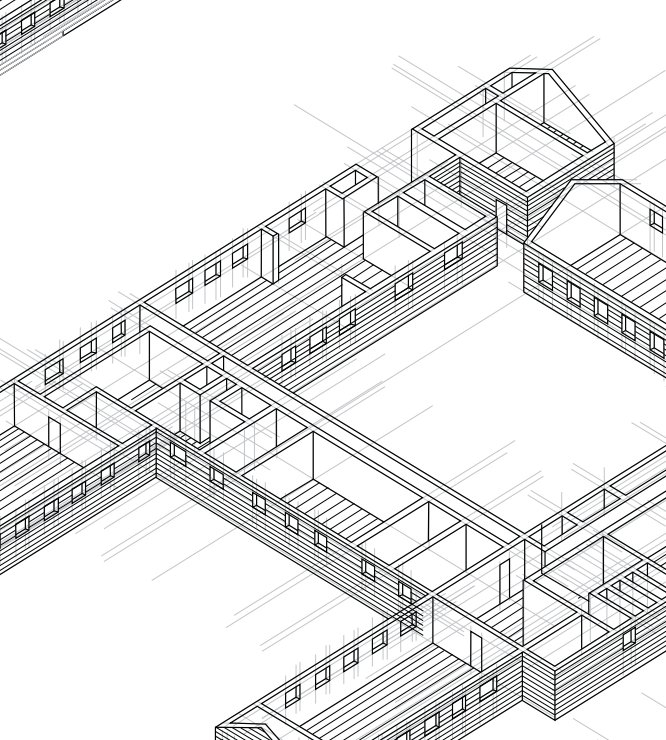


\section{Entombment}

Entombment sees the former day room made inaccessible, a

tomb to the memory of neglect but from the exterior visually the same.
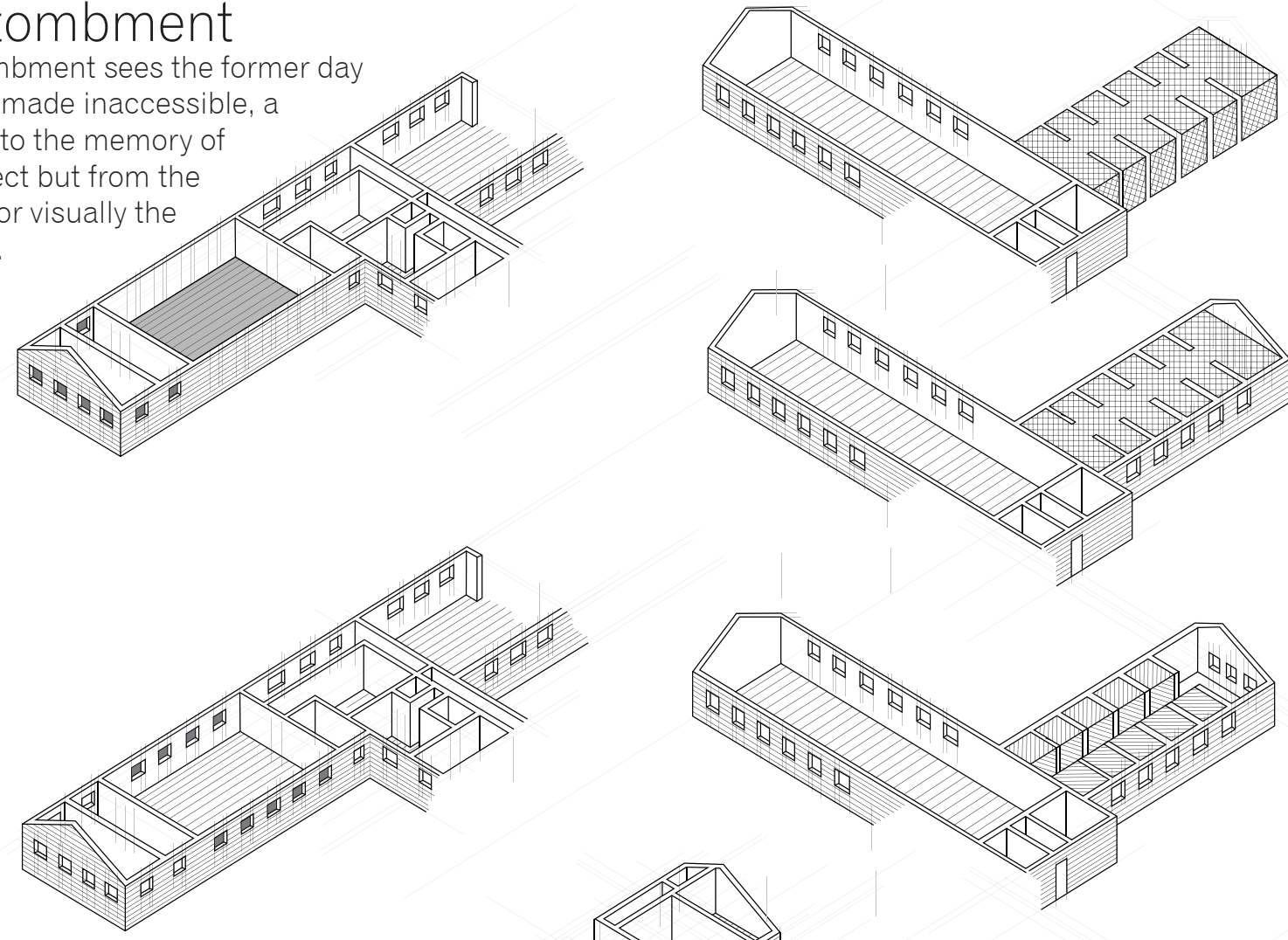

Filling In

Here the

monumentalization of filled in space is shown over time.
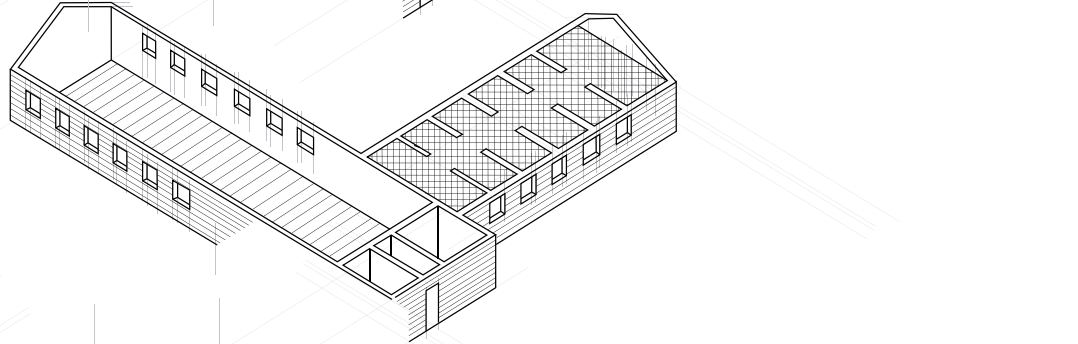

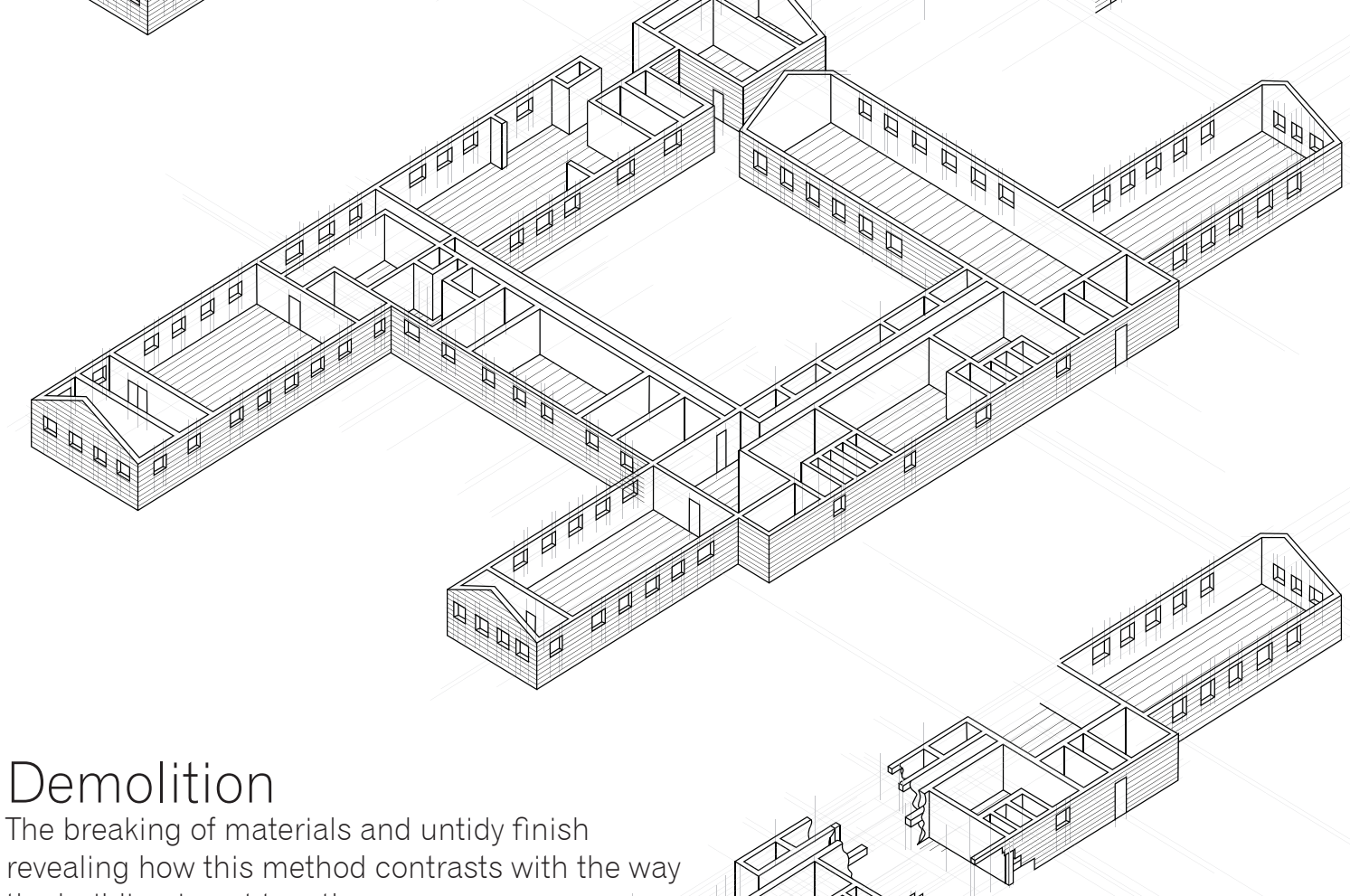

the building is put together.

\section{Re-Surfacing}

Here re-surfacing is showing a new facade covering up the damage made during demolition

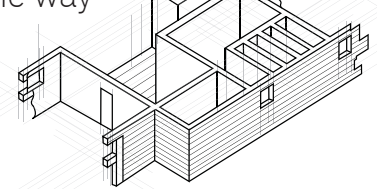



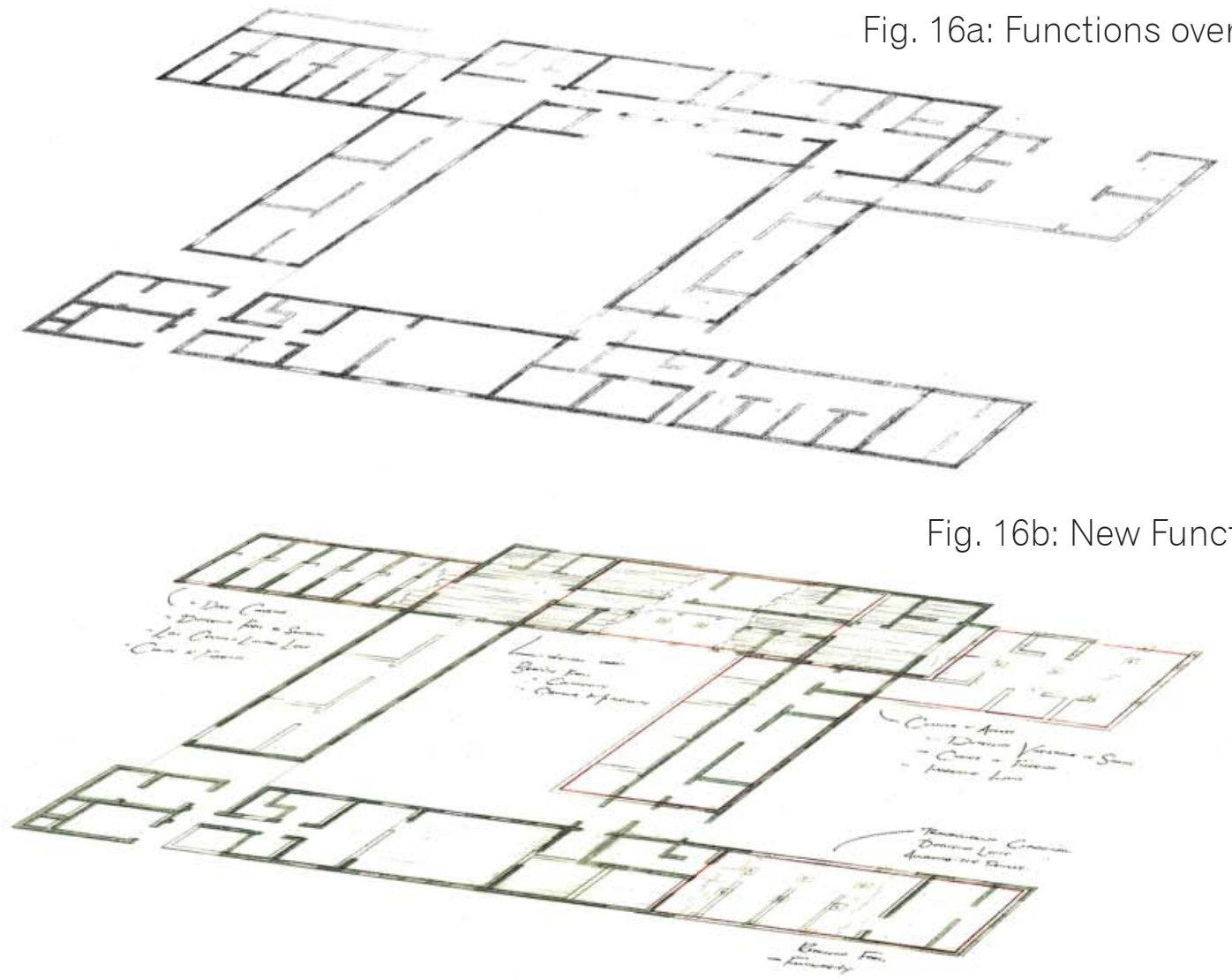

tions
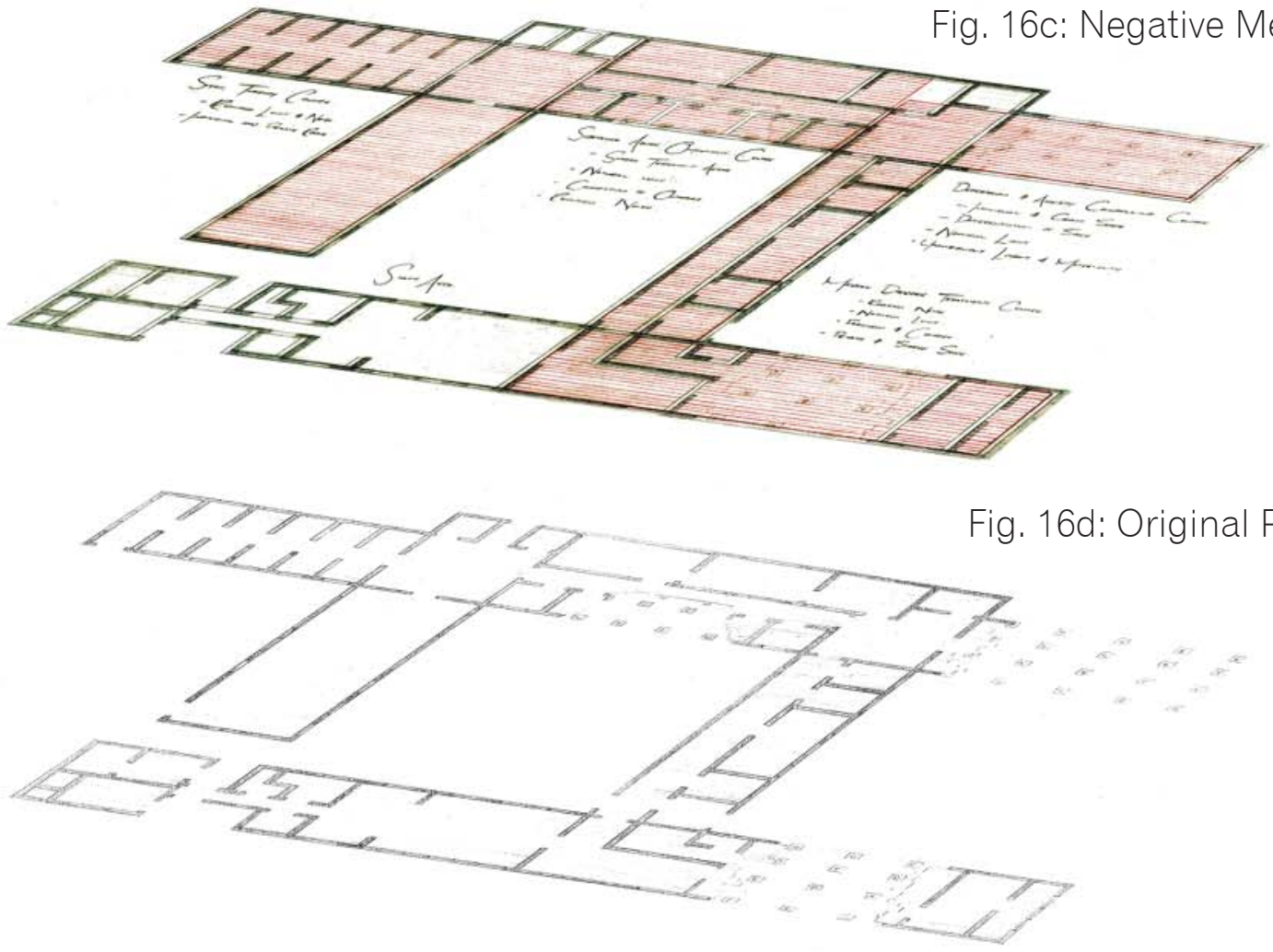

Fig. 16: The layers used in the planning of the building, showing the original plan (Fig.16d), with the parts of the building identified as most potent with negative memory in red (Fig. 16c). The new function has been outlined over the areas of negative memory with designated space determined by the requirements specified in the brief. Above these layers erasure techniques are drawn. This iterative layering continued until the design was developed and refined. 
Fig. 17a: Original Section

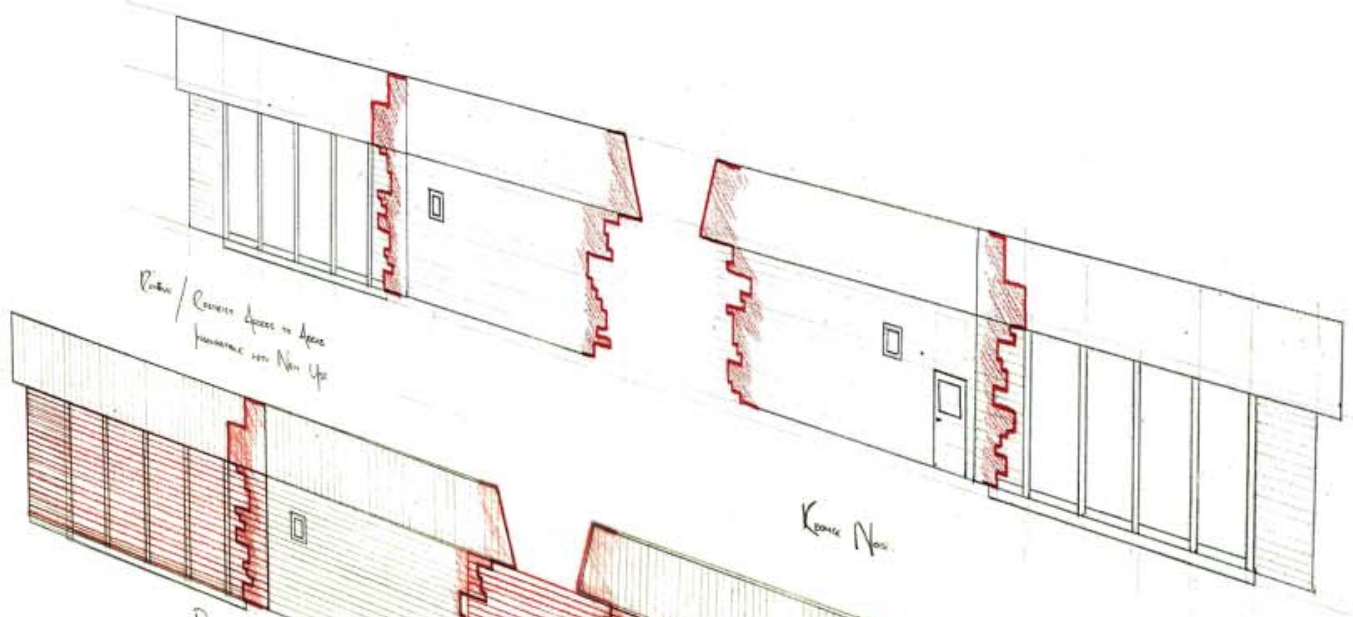

Fig. 17b: Negative Memory

Fig. 17c: Selective Demolition

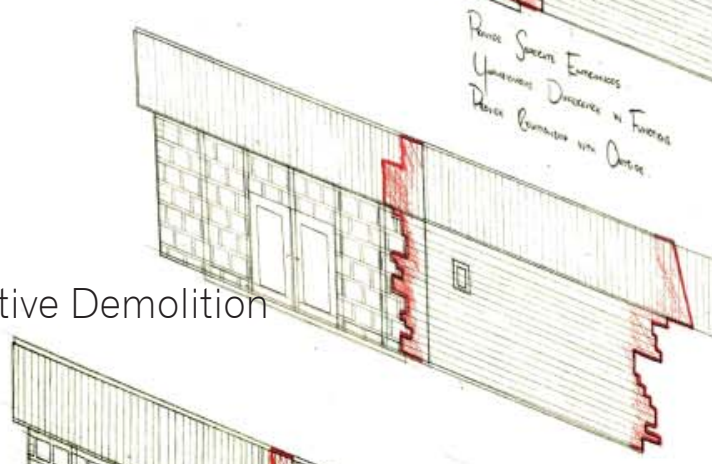

Fig. 17d: Re-Surfacing
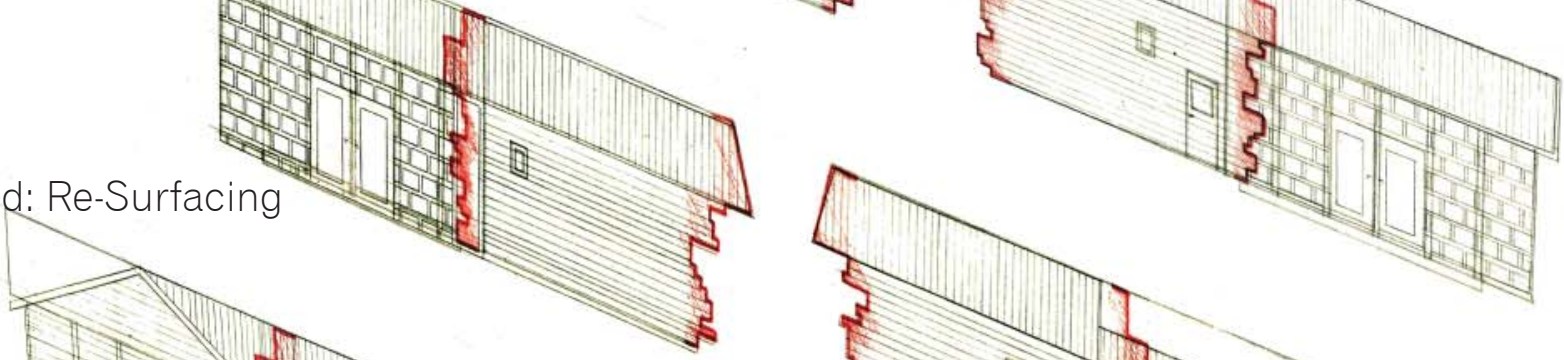

Fig. 17e: Functions over Erasure

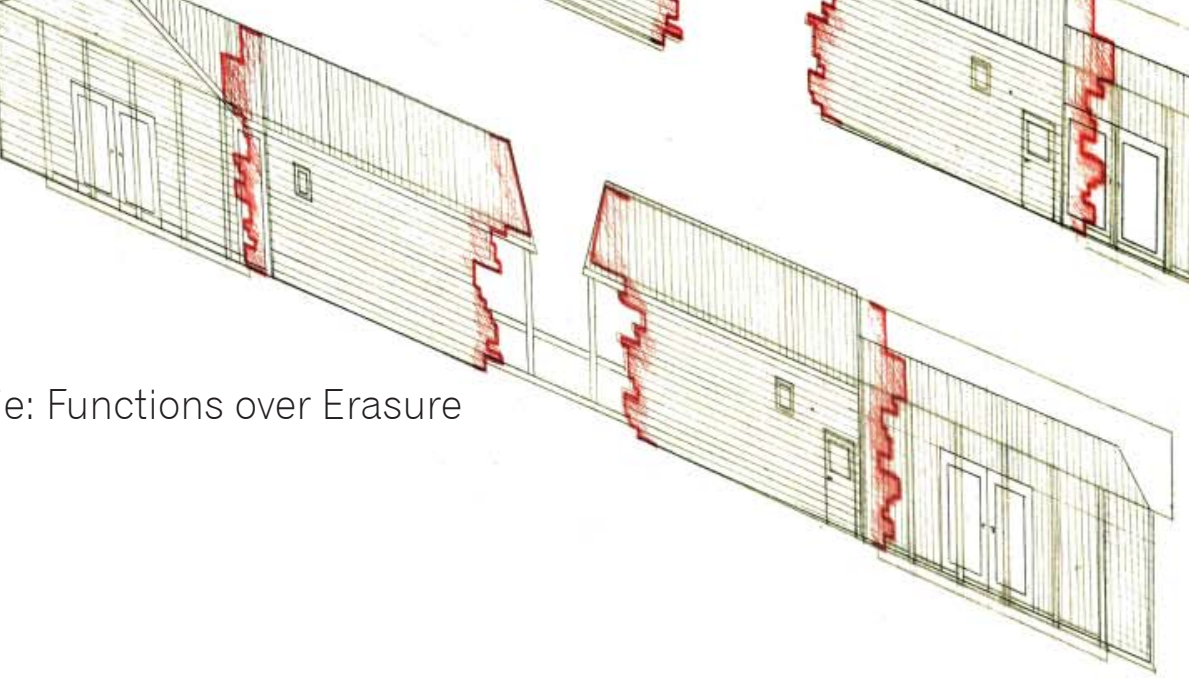

Fig. 17: The original elevation with the breaks between potent memory and less potent memory marked as in accordance with the plan (Fig. 18). Again, the parts of the building identified as most potent with negative memory are in red over top (Fig. 17b), the erasure techniques are then shown individually here, experimenting with different ways to break up the uses with the practical needs of the functions layered over top (Fig. 17c - 17e). This layering continued until the design was developed and refined. 


\section{Initial Design}

The design shows the four different clinics expressed in the brief laid out in the building.

The Personality and Mood Disorder clinic has been separated from the rest of the clinics using external walkways and is further isolated by being re-surfaced and lowered into the ground. It uses it re-surfacing and its position at the front of the building to provide an active connection to the reality going on outside and to plenty of natural light.

The Sleep Disorder clinic, extended beyond the original building footprint, is also re-surfaced to facilitate its new use. It is positioned on the southern edge of the building with minimal natural light and noise. Its resurfacing to a vertical lined facade separates it subtly from the old.

The Depression and Anxiety Counselling Centre is positioned at the front of the building and is the first clinic visitors will come across, for this reason its main entrance has been angled toward the rest of the site. This location position will also provide plenty of natural light and a connection to the outside. Multiple exits and entrances provide patients plenty of choice and remove restrictions. The front part of the centre replaces the demolished former dormitory and the entire centre has been re-surfaced on the inside to provide a soft and comfortable environment.

The Substance Abuse clinic is located in the centre of the building with the former medical rooms demolished, the scars of the removal left clearly visible. It has group and individual therapy rooms that face inward, with plenty of glass to provide transparency. Several overnight rooms will be shared between the Sleep Therapy and Substance Abuse clinics for emergency overnight care.

All four clinics will also share staff, storage and utility facilities in order to keep the overall building compact and provide some coherency between each individual clinic. 
Personality \& Mood Disorder Clinic

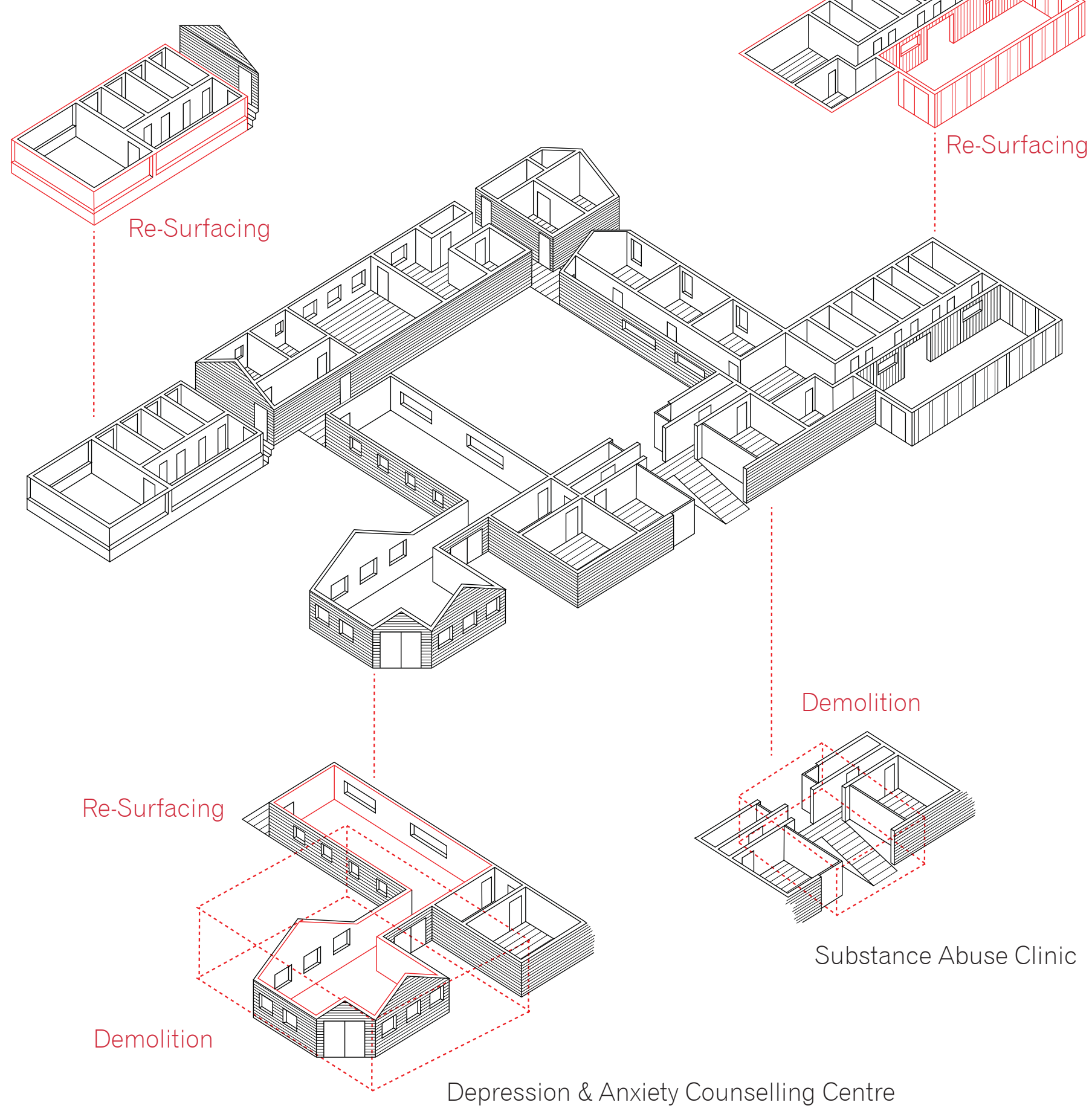





\section{Sleep Therapy Clinic}

The sleep therapy clinic is located in the former south dormitory, in the quietest part of the site away from noise and direct northern light. The clinic requires a relatively simple and predictable plan that is easily legible, with transition zones from the brightness of outside to the darkness of the clinical exam rooms. To provide this an extension has been added beyond the original footprint to accommodate a waiting room constructed in a gauzy light filtering material with a low ceiling and soft furnishings to simulate a dream like experience that provides a gradual transition from outside to in. The clinic also shares a series of short stay rooms with the neighbouring substance abuse clinic for the possibility of emergency overnight treatment.

While the plan layout is very similar to the original, the extension, change of access and manipulation of light changes the experience of entering and being in the building, diffusing the negative memory. For the clinic re-surfacing was used as an erasure technique with a change of facade treatment (shown in elevation and section on page 93) to not only differentiate its use from the rest of the building but also to differentiate it from its past use and any associated negative memory attached to its appearance. 


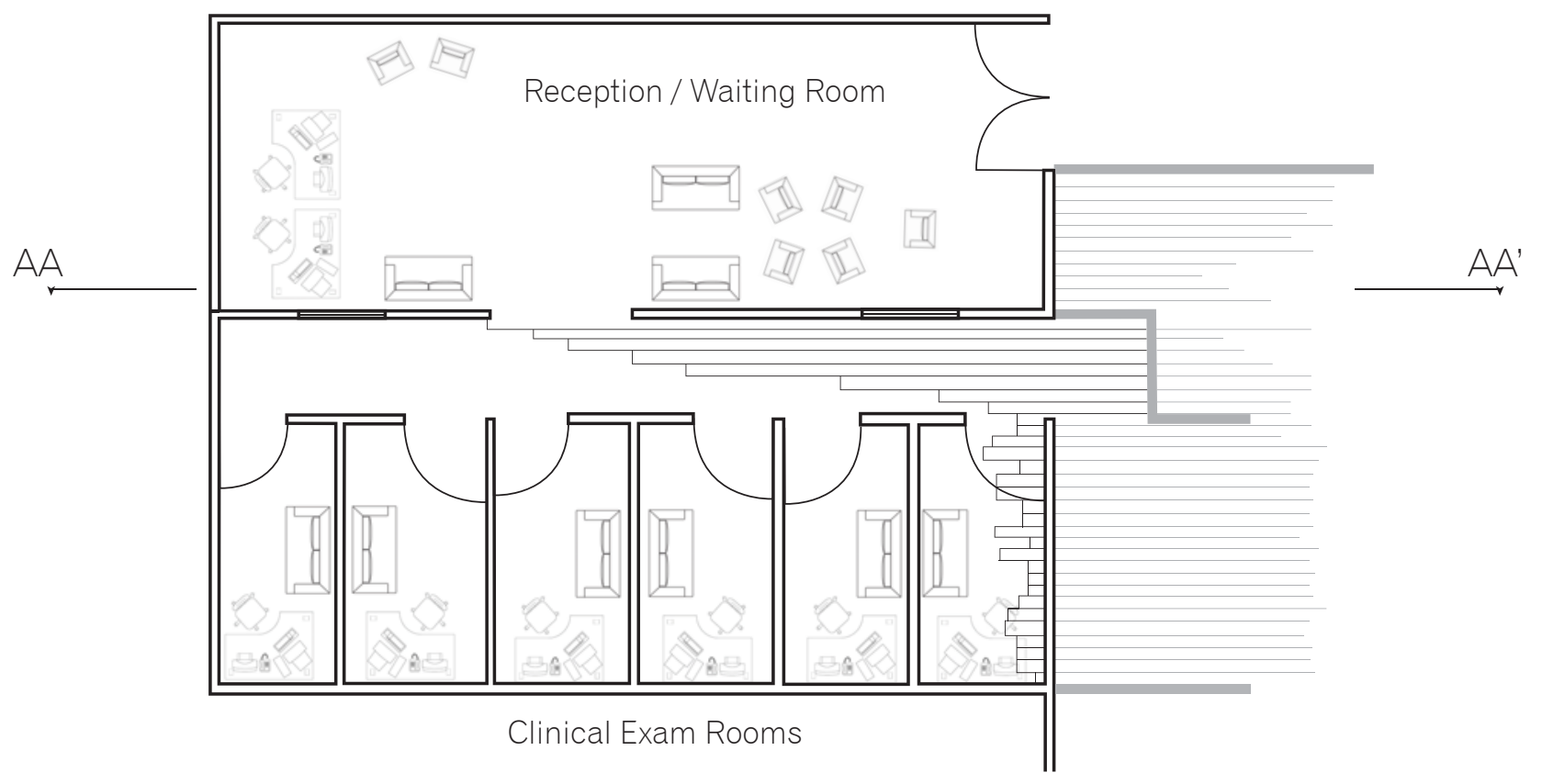

Plan

Elevation

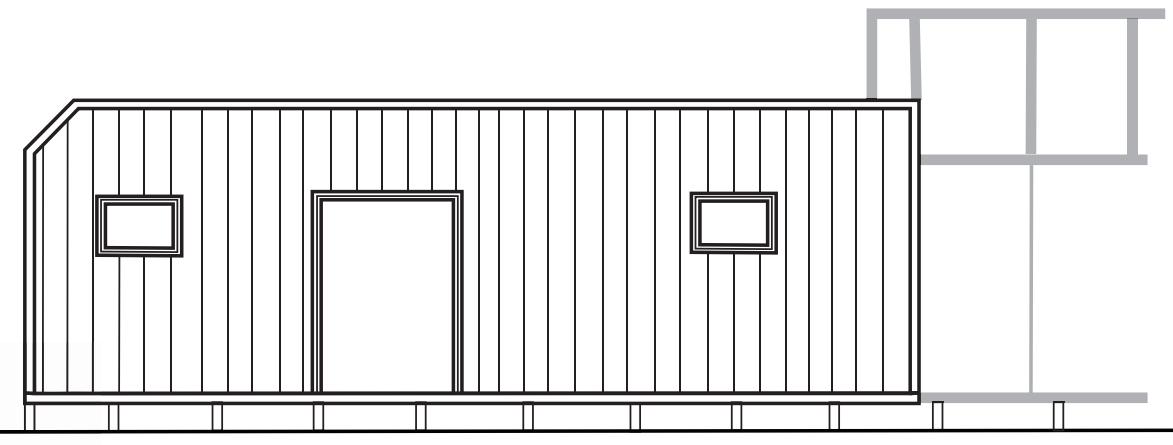

Section AA - AA' 


\section{Substance Abuse Clinic}

The substance abuse clinic is situated in the centre of the building where the former medical treatment room, solitary confinement cells and bathrooms were once situated. The clinic includes both group and individual therapy rooms with transparent inward faces creating a complex view of the demolished remnants of the building, designed to provide distraction and freedom of choice and comfort to the patients. The spaces are all individual with a strong connection to the outside and varying infiltrations of natural light. This connection to the outside is deemed highly rehabilitative in the literature. As previously mentioned, a series of short stay rooms are also provided for emergency 24 hour rehabilitative care.

The former uses have been selectively demolished from the footprint of the building; the scars of their removal left evident to acknowledge the negative memory and express distance and separation between the old and the new. The new use is too closely related to this former use and returning the building to use was deemed inappropriate during the site evaluation. Removing all remnants of these negatively connotated uses will better separate the old and the new and allow the building to still be occupied by the new use. 


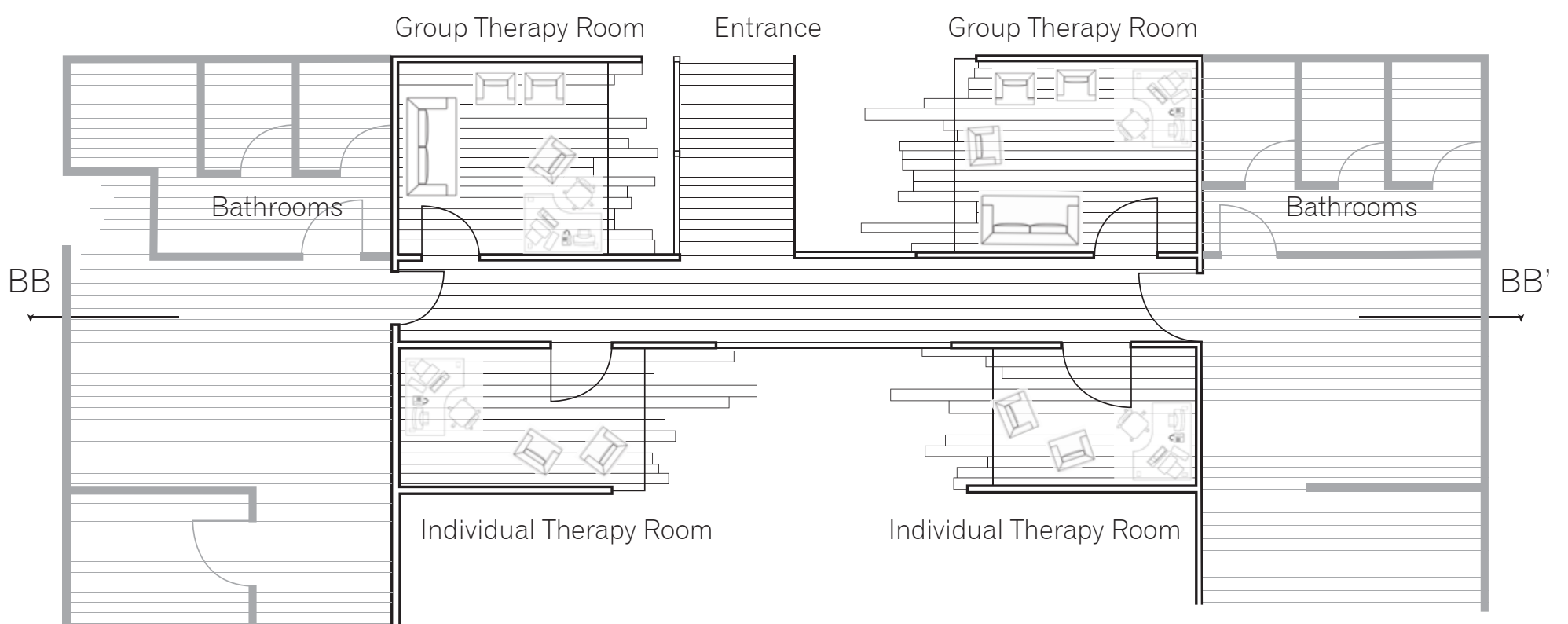

Short Stay Rooms

Plan

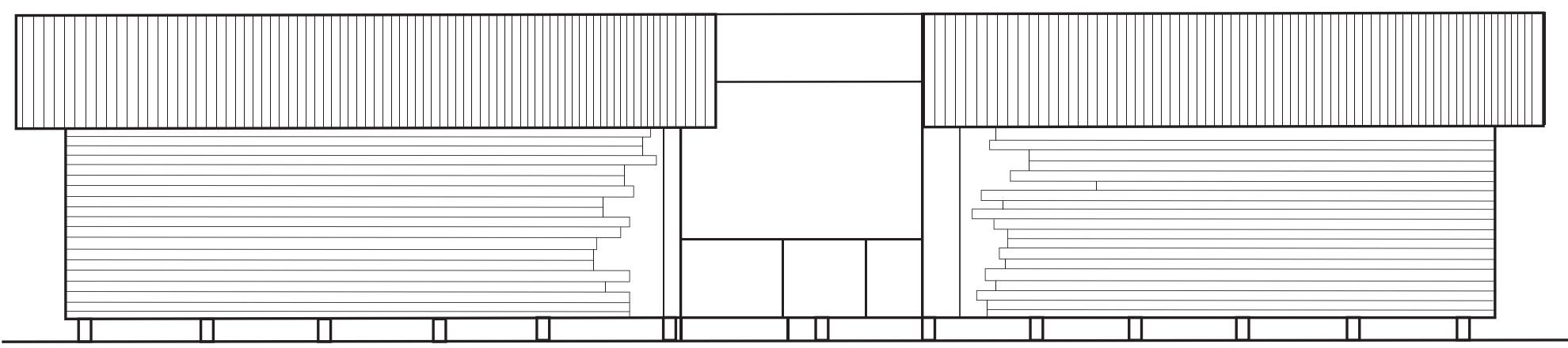

Elevation

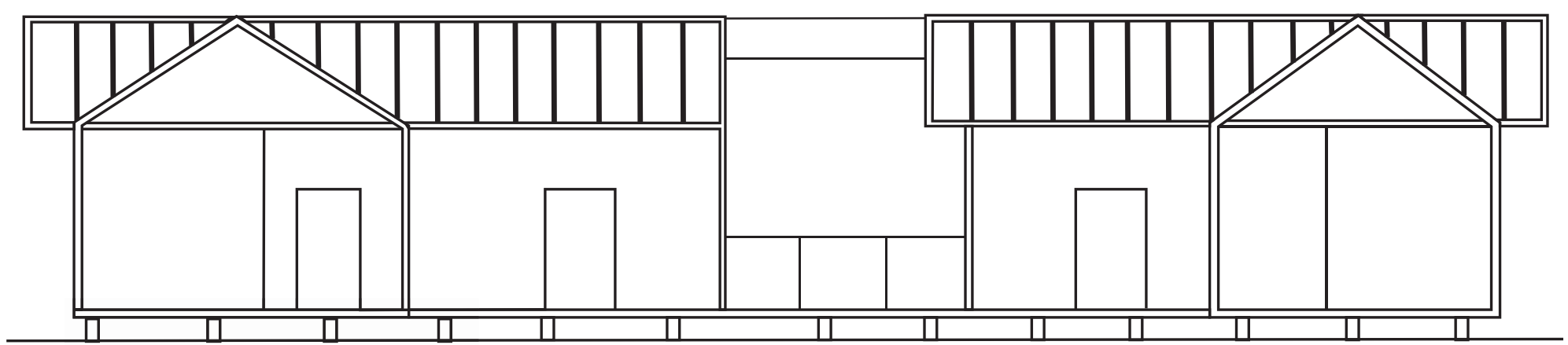

Section BB - BB' 


\section{Depression and Anxiety Counselling Centre}

The counselling centre for those suffering from depression and anxiety is situated at the front of the building, with an entrance facing the rest of the site. Being on the north side of the building it gets the most natural light and provides a strong connection to the world. The centre is a flexible space with no conventional office space but instead moveable partitions and furnishings offer freedom of choice and comfortable options for a range of therapy methods. The centre also has three entrances and exits so that users do not have to enter the same way they came in, offering an environment completely at the liberty of the user.

The centre uses selective demolition less explicitly than the substance abuse clinic simply by removing the former north dormitory and providing a new extension in its plan with a much more open plan, changing the main access and approach to the building. By separating the main entrance of the centre from the entirety of the rest of the building a differentiation between past and future uses is created. The flexibility and number of entrances and exits, also contrasts the once controlling plan and subverts the underlying negative memory of the former dormitory space. 


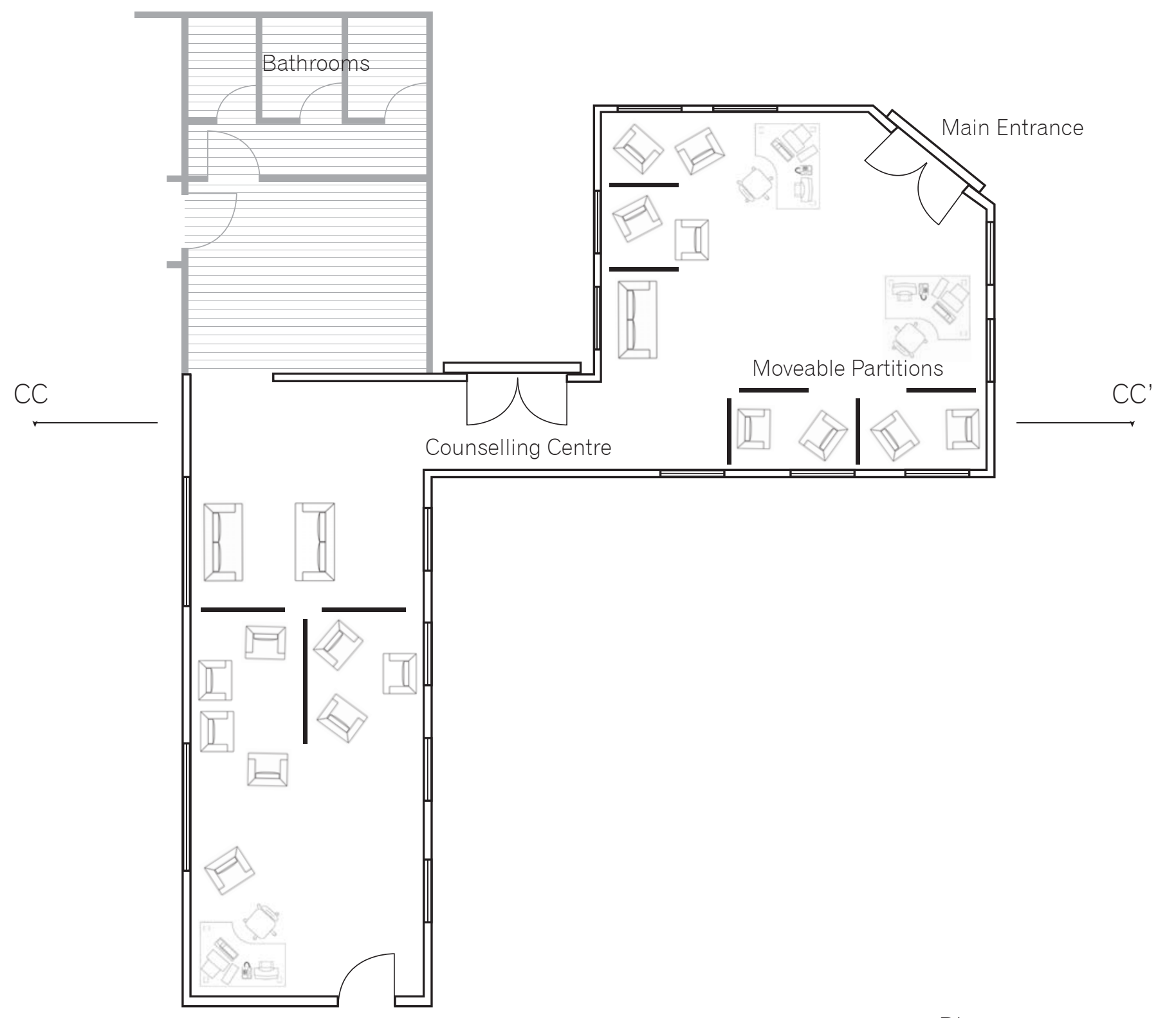

Plan

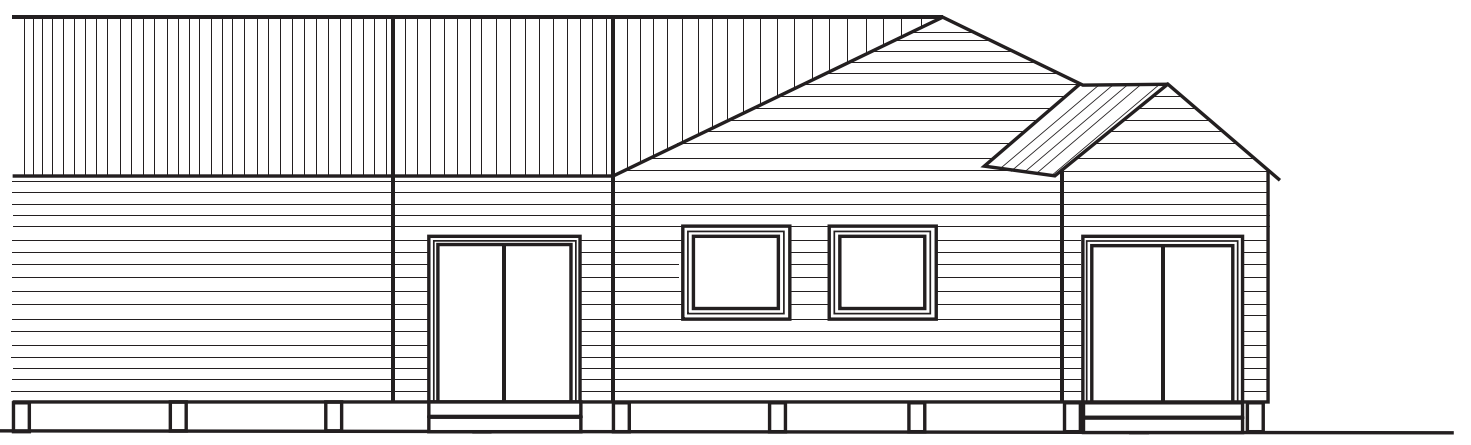

Elevation

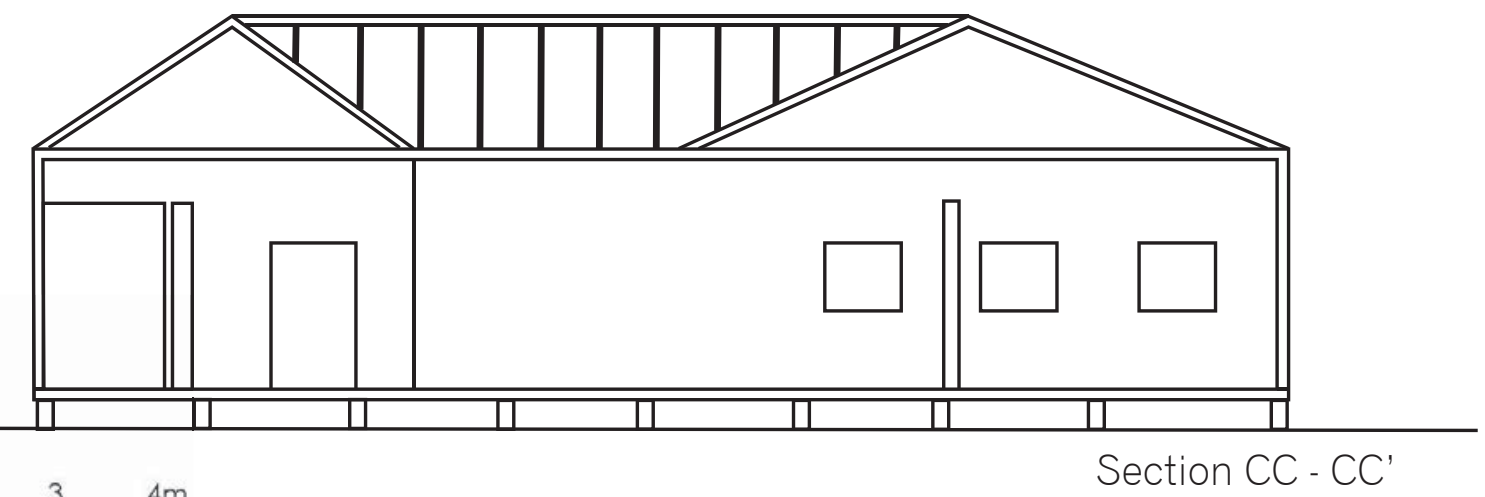




\section{Personality and Mood Disorder Clinic}

The Personality and Mood Disorder clinic is located in the north east wing, isolated from the other treatment centres. The treatment centre requires an isolated and rigid plan that is familiar to its patients and it is for this reason that it is situated in the part of the building that was once the old day room. This isolation is also exaggerated by the fact that the clinic has been lowered into the ground below the rest of the building, with diffuse light coming in only from around the tops of the walls. The plan is rigid with four clinical treatment rooms and a single waiting room as well as bathrooms close by and a single entrance and exit. The clinic has a low ceiling and soft furnishings in order to diffuse noise and control light.

The disorder clinic uses re-surfacing to change its appearance and therefore its association with the building and its former use. Its isolation from the rest of the building, isolates the new use from the old one and any negative memories, by changing access and the flow between inside and outside. 


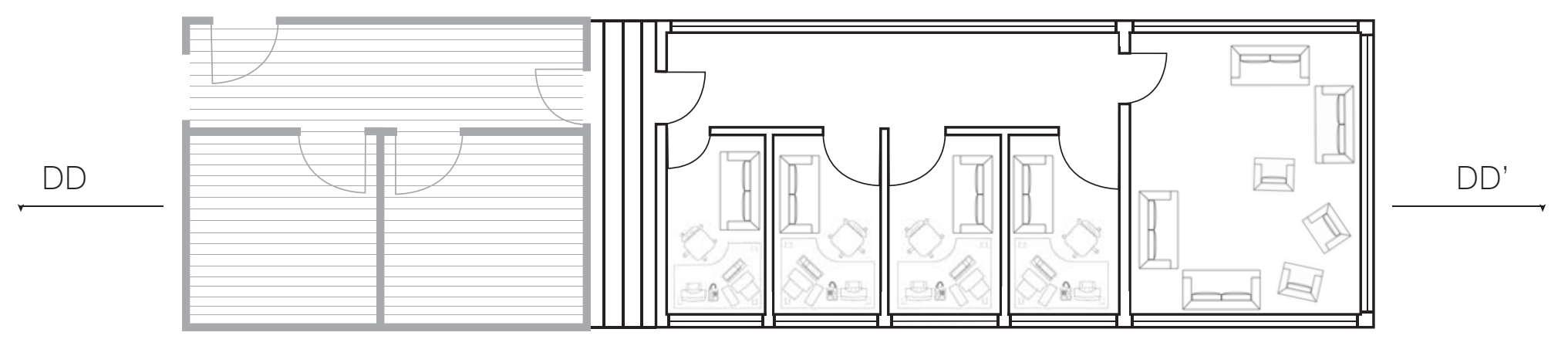

Plan

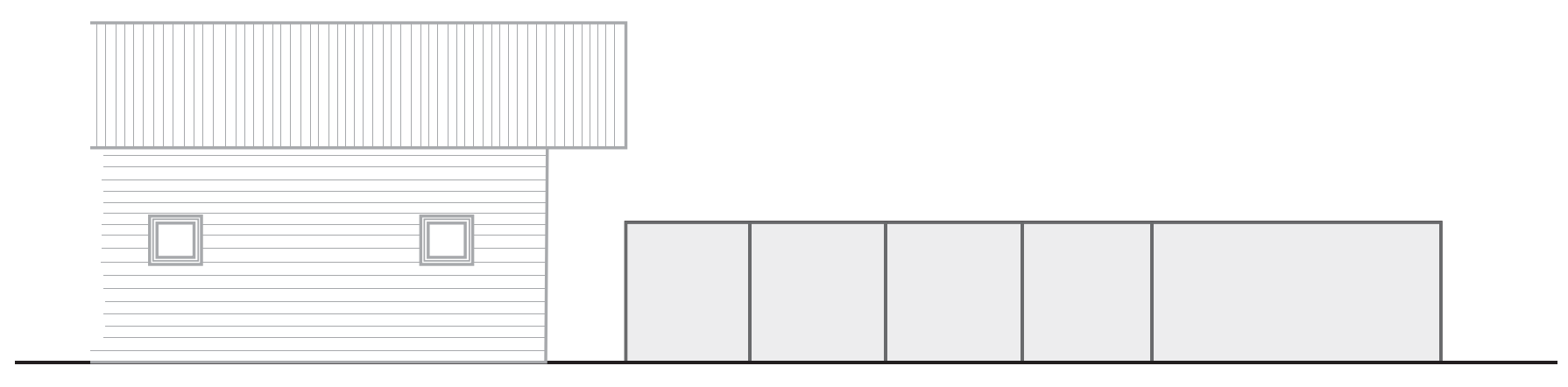

Elevation

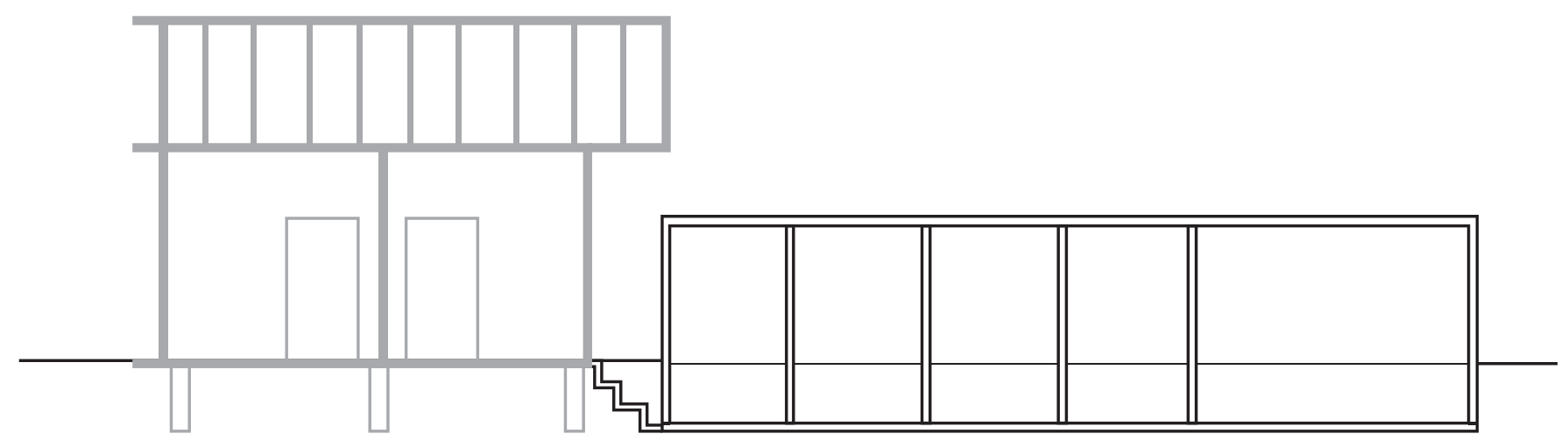

Section DD - DD'

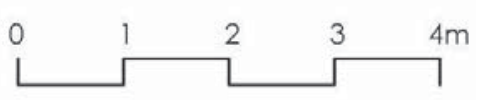





\section{Conclusion}

\section{Design Conclusion}

The initial design created, while testing the draft design process in the previous chapter is far from finished, it requires further detailing and refining through the layering process. In this design the distinction between places so potent they demand erasure and those that are available for reuse has been exaggerated in order to experiment with how negative memory can be integrated and acknowledged with a new use by matching four distinct new uses with four sources of negative memory demanding distinct access, appearance and atmosphere. What it shows however is one possible outcome of this process which with variations in criteria can create completely different outcomes. While it is unknown whether the community would accept this as a design proposal it does show a possible way of integrating negative memory with a practical new use.

This process for the design of negatively connotated places is purposely designed to allow for us to constantly remake and renegotiate our relationship with a place. As more revelations are made about a site it may move in our minds between the poles of transformation and erasure as discovered in the initial case study analysis. I chose Kimberley because it was a site currently dealing with an evolving stigma, however this meant that the constant renegotiation with what we understand about and how we read the site not only became a difficulty I had to overcome in my design but an important part of the test of this design process. In terms of timing this site is rare, in that it is in the midst of upheaval. Its place in the collective memory is not yet settled and therefore the evaluation of the site and its fitness for reuse is constantly in flux. In the age of mass media and our moral need to come to terms with a painful past many sites like Kimberley are likely to go through a cycle of public acceptance and condemnation and evaluating this and designing for it is difficult. The design produced by following this process has not been re-evaluated in the context of changing opinion but this is another important part of the process that needs to be evaluated, in the case of the Kimberley site this re-evaluation may take place in three years when the Royal Commission of Inquiry reports on its findings. 



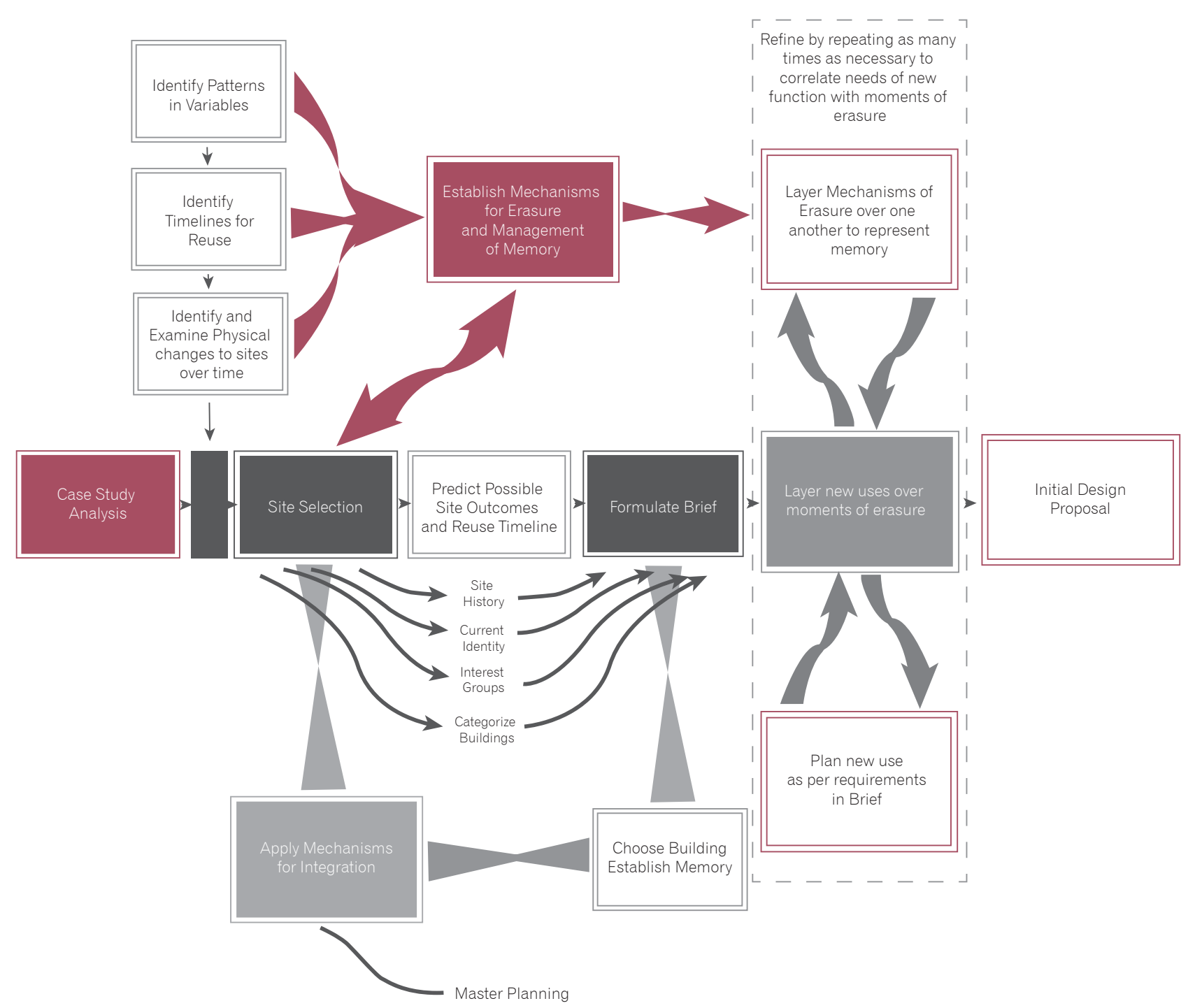

\section{Adapted Design Process}

Above is the adapted process actually undertaken when undertaking the design experiment on the Kimberley Centre, it shows the initial flaws in the process and where extra steps needed to be added in. The biggest issue, already mentioned in Chapter 4 (pp77) is that this site and any site for that matter has to be adapted to represent site specific parameters.

The biggest issues with applying the process to this site were to do with size and location. To focus on integrating the site into the surrounding community means ignoring more specific parts of the site identity. With such a large site these specific memories can be ignored or overlooked and as previously mentioned, negotiating and acknowledging these memories is the central aim of this thesis. As a part of this experiment, I broke down the site and focussed on applying this to a singular building, to further test the extents of this draft process, however beyond the specifics of this site it will be important to work at a small scale and work outwards whatever the size of the site. Master planning cannot be completely removed from the design process but should be considered as secondary to managing the memory and identity of the site.

Sites of varying sizes and locations are likely to fit into this process better than others. Many may reach the input of data stage and be unusable, others will need to be broken down and different parts of the site put through the process individually. Some parts of the site may be more usable than others in terms of their memory and categorisation and therefore, some parts may be able to be developed while others cannot. In sites spread out like Kimberley this will be easy, but in large buildings with multiple uses all located under one roof this will be harder to negotiate. In some situations extra steps may need to be added into the brief in order to break down this process and explicitly break down uses. 



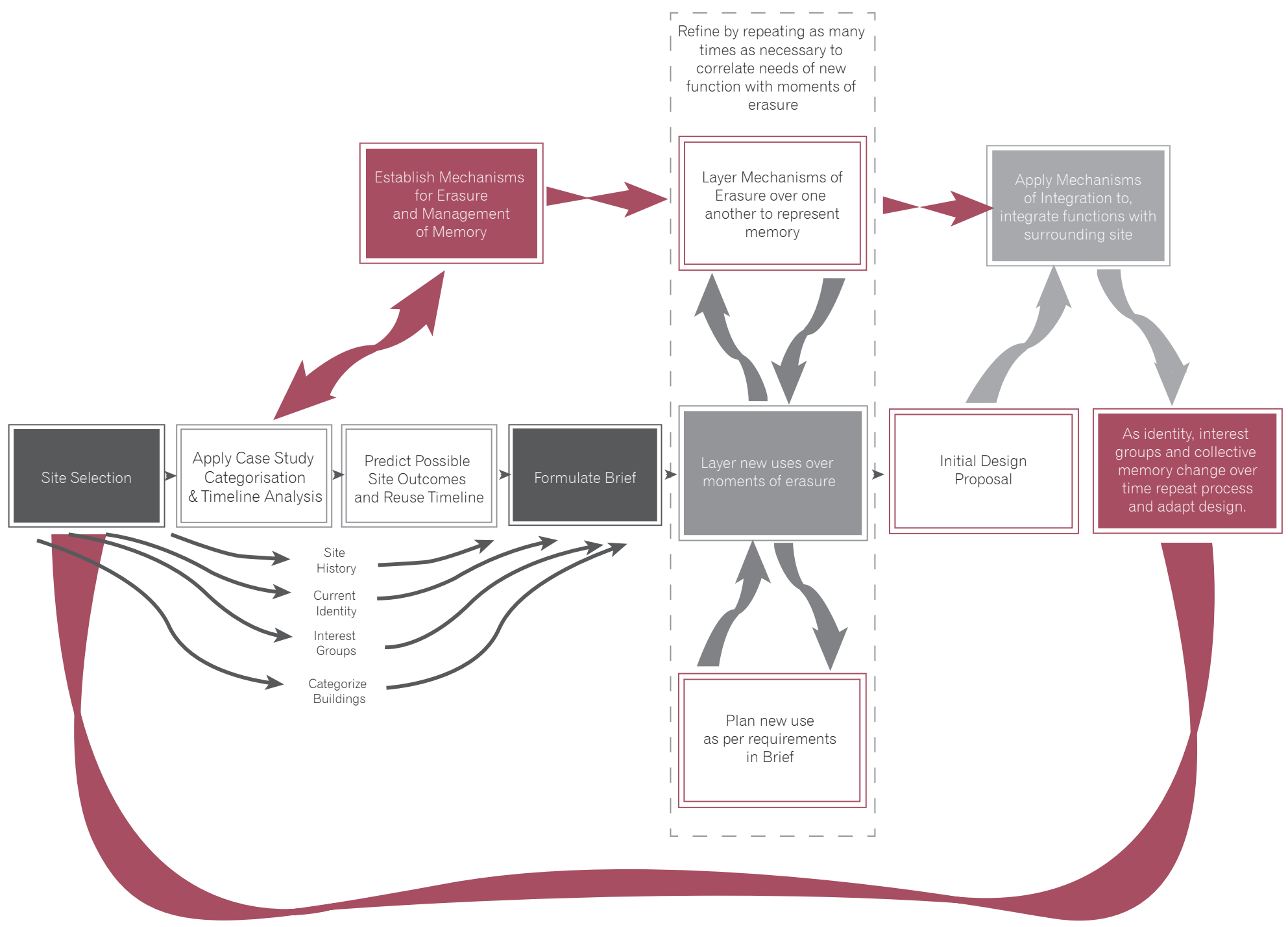

\section{Applicable Process}

On reflection the most important element of this process to consider is its ability to be replicated across a range of negatively connotated places.

The initial draft process and the adapted design process on the previous page are based on the original case study analysis and then the design experiment I undertook. Due to the limitations of this thesis I used the initial case study analysis to select a site of which presented an ideal set of parameters to experiment with the initial process I had developed, including location, current identity, interest groups and the physical remains of the site. Even this 'ideal' site presented many issues for the process I had designed.

However in a real life scenario, the selection of a site is likely to be the instigator for the use of this process. Not everyone designing on sites of negative heritage is going to carry out a thorough case study analysis such as mine, rather they are going to use the data I have collected here as input into their own design process, the same way they input site history and current identity in order to determine the usability of the site and its points of erasure. The process above has been adapted slightly to reflect this scenario. The individual parameters of the site can then be plugged into the process the same way as the original data to produce a design brief for the adaptive reuse of the site. 

This thesis ultimately has two key outcomes. The first is a categorisation process that allows a developer, designer or owner to evaluate the usability of the site by inputting a series of site variables, such as use, event, political and social conditions and the survival of the record. It also evaluates timelines of usability for these sites considering these same variables and the timelines of sites that have come before. This analysis has opened plenty of lines of inquiry that are beyond the scope of this thesis, how we measure the impact of an event on society and the influence this has on places, the way that the changing moral implications of saving places of negative heritage has altered our overall landscape and the way the passing of time captures the collective memory and what this has to say about the remnants of some of the twentieth century's worst atrocities.

The second is the development of a process (pp105) for the adaptive reuse of negatively connotated places. Ultimately this process can be adapted to multiple sites of pain and shame, incorporating the evaluation of the usability of the site based on the case study data into the design process. There is no one size fits all approach to the reuse of negative heritage buildings, some sites should simply never be reused, which is why this process allows for the evaluation of a site using its own history, timeline and interest groups as variables for the design stage. This process relies heavily on the case study data to make its evaluations but with the understanding that this process is not going to work the same for every site, that sites may need to be broken down and evaluated in parts, or may fall outside the parameters of what we know from the data.

What this thesis set out to do was draw lines between the political, cultural and social conditions surrounding a site and their final architectural outcome. Design, in some cases can bridge the gap between usability and obsolescence, by respecting and acknowledging negative memory in the reuse of a building and using it as an influence over the design of the new use. Collective memory has implications for the way particular cultural heritage sites have evolved over time. This in turn has implications for contemporary understanding and management of the built environment. In the modern era we see shunned sites reconstructed for memorial purposes, we sleep in hotels which once housed prisoners, we pull once revered statues to the ground, and we travel extreme distances to stand at the edge of mass graves. Collective memory changes our perceptions of space and what remains in our environment, not just to be remembered but to be glorified. This thesis has used the perceptions of collective memory to evaluate, categorise, manage and design for negatively connotated places where the tendency to obliterate traumatized sites - whether materially or psychologically - must be rationalized with the effort to frame architecture as a container of sets of events. A multifaceted collection of histories in context. 



\section{Reference List}

Ansley, B. (2007, June). Meltdown: Death of a Family. The Listener.

Arrhenius, T. (2012). The Fragile Monument: on Conservation and Modernity. London: Artifice Books.

Ashworth, G. (2002). Review of 'Dark Tourism: The Attraction of Death and Disaster. Tourism Management, 190-191.

BBC News. (2013, June). Josef Fritzl's Cellar in Austria to Concreted in. BBC News.

Brown, T., \& McAvine, S. (2017, August). Address may be Infamous, But it's Still Home. Otago Daily Times,

Bryan-Wilson, J. (2003). Building a Marker of Nuclear Warning. In R. S. Nelson, \& M. Olin, Monuments and Memory, Made and Unmade (pp. 183-204). Chicago: University of Chicago Press.

Burstrom, M., \& Gelderblom, B. (2011). Dealing with Difficult Heritage: the case of Buckeberg, site of the Third Reich Harvest Festival. Journal of Social Archaeology, 266-282.

Chadha, A. (2006). Ambivalent Heritage. Journal of Material Culture, 339-363.

Cockroft, S. (2016, December). The Houses of Horrors. The New Yorker.

Connellan, K., Garradboe, M., Riggs, D., Due, C., Reinschimdt, A., \& \& Mustillo, L. (2013). Stressed Spaces: Mental Health and Architecture. Health Environments Research \& Design Journal, 127168.

David, C. (2015, August). 'We are Taking the Island Back': Norway's Long Road back to Utoya. The Guardian.

Devlin, C., \& Hunt, T. (2017, August). What's Next for Mt. Crawford as LINZ moves ahead with disposal of prison site? The Dominion Post.

El Richani, D. (2015). Dead Spaces, Living Architecture and the Functionality of Deat in PostConflict Settings. Social Sciences, 1118-1126.

Field-Murray, W., Nieves-Zedeno, M., Hollenback, K., Grinnel, C., \& Crows-Breat, E. (2011). The Remaking of Lake Sakakawea: Locating Cultural Viability in Negative Heritage on the Missouri River. Journal of the American Ethnological Society, 468-483.

Fitch-Little, H., \& Muong, V. (2015, August). Dark Tourism in Anlong Veng. The Phnom Penh Post. Foote, K. E. (1997). Shadowed Ground: America's Landscapes of Violence and Tragedy. Austin, TX: University of Texas Press.

Galuszka, J. (2014, May). 'Local Developer' Snaps up Building. Manawatu Standard.

Hawthorne, C. (2016, August). At Sandy Hook Elementary, A New Campus and new start at site of Horror. LA Times.

Hunt, A. (2000). The Lost Years: From Levin Mental Deficiency Farm to Kimberley Centre. Auckland. Joshi, M., \& Amritha, B. (2012). Bhopal Gas Tragedy. Museum and the Community, 7-14.

Kohlbacher, F. (2006). The Use of Qualitative Content Analysis in Case Study Research. Forum: Qualitative Social Research, 1-20.

Langenbach, R. (1992). The Good and The Evil: The Preservation of Monuments with a Negative Symbolic Image. In L. H. Schneekloth, M. F. Feuerstein, \& B. A. Campagna, Changing Places: remaking Institutional Buildings (pp. 159-198). New York City: White Pine Press.

Legg, G. (2016, May). Redeveloping the Long Kesh/Maze Prison: Profiting from the Hunger Strikes? The Irish Times. 
Lennon, J., \& Foley, M. (2000). Dark Tourism: The attraction of Death and Disaster. London: Continuum.

Logan, W., \& Reeves, K. (2009). Places of Pain and Shame: Dealing with Difficult Heritage. Abingdon: Routledge.

Lowenthal, D. (1996). Possessed by the Past. New York City: Free Press.

Luna, R. (2013). Life of a Shell and the Collective Memory of the City. IntAR Interventions and Adaptive Reuse, Vol 4 Difficult Memories: Reconciling Meaning, 30-35.

Macdonald, S. (1997). A People's Story: Heritage, Identity, and Authenticity. In C. Rojek, \& J. Urry, Touring Cultures (pp. 155-176). London: Routledge.

Macdonald, S. (2009). Difficult Heritage: Negotiating the Nazi past and Nuremberg and Beyond. London: Routledge.

Macdonald, S. (2016). Is 'Difficult Heritage' still 'Difficult'? Museum International, 6-20.

McAtackney, L. (2014). An Archaeology of the Troubles: The Dark Heritage of Long Kesh/Maze Prison. Oxford: Oxford University Press.

Meskell, L. (2002). Negative Heritage and Past Mastering in Archaeology. Anthropological Quarterly, 557-574.

Miles, W. F. (2002). Auschwitz: Museum Interpretation and Darker Tourism. Annals of Tourism Research, 1175-1178.

Mirfin-Veitch, B., \& Conder, J. (2017). 'Institutions are Places of Abuse': The Experiences of Disabled Children and Adults in State Care between 1950-1992. Dunedin: The Donald Beasley Institute.

Moses, S. (2015). Stigmatized Space: Negative Heritage in Historic Preservation. Thesis. Philadelphia: University of Pennsylvania.

Newhub. (2008, September). Mixed Feelings from Residents over Kimberley Closure. Newshub.

Oliphant, R. (2016, April). 30 Years after Chernobyl Disaster, Wildife thriving in Radioactive Wasteland. The Telegraph.

Reader, I. (2003). Review of 'Dark Tourism: The Attraction of Death and Disaster'.

Rico, T. (2013). Negative Heritage: The Place of Conflict in World Heritage. Conservation and Management of Archaelogical Sites, 344-352.

Seaton, A. (1996). Guided by the Dark: From Thanatopsis to Thanatourism. International Journal of Heritage Studies, 234-44.

Sharpley, R. (2005). Travels to the Edge of Darkness: Towards a Typology of Dark Tourism. In C. Ryan, S. Page, \& M. Aicken, Taking Tourism to the Limit. London: Elsevier.

Sinclair, K. (2009, April). Bain Agreed to Razing Family Home, Court Told. Otago Daily Times.

Smith, L.-J. (2007). Uses of Heritage. Routledge: New York.

Stanley, E. (2016). The Road to Hell: State Violence Against Children in Postwar New Zealand. Auckland: Auckland University Press.

Stone, P. (2006). A Dark Tourism Spectrum. Tourism, 145-160.

Stone, P., \& Sharpley, R. (2008). Consuming Dark Tourism: A Thanatological Perspective. Annals of Tourism Research, 574-595. 
Strange, C., \& Kempa, M. (2003). Shades of Dark Tourism: Alcatraz \& Robben Island. Annals of Tourism Research, 386-405.

Tarlow, P. (2005). Dark Tourism: the Appealing 'Dark Side' of Tourism and More. In M. Novelli, Niche Tourism - Contemporary Issues, Trends and Cases (pp. 47-58). Oxford: Butterworth-Heinemann.

Tunbridge, J., \& Ashworth, G. (1996). Dissonant Heritage: The Management of the Past as a Resource in Conflict. John Wiley \& Sons: West Sussex. 



\section{Appendix A: Case Studies Data}

The original case study data as reference material for the analysis carried out in Chapter 3. All 70 case studies are profiled here in alphabetical order. Some variables are consistent across all the case studies, others are specific to the outcome of the building. The data is taken from a range of sources including media articles, books, encyclopedias and journal articles. 

Data REDACTED by Author due to Copyright Concerns. Pages 114 - 187 have been removed and can be found on the published physical copy of this thesis. 



\section{Appendix B: Case Study Physical Analysis}

Following on from the case study analysis, an in depth physical and historial analysis was done of a selction of sites to evaluate how physical changes on the site correlate with different social and political changes happening at the time within the context and effecting the collective memory. This physical analysis also allowed an in depth look at the different techniques of erasure used on these sites and the circumstances when they took place. These erasure techniques can be found detailed and explained on pp 200. 


\section{Long Kesh / Maze Prison Detailed History}

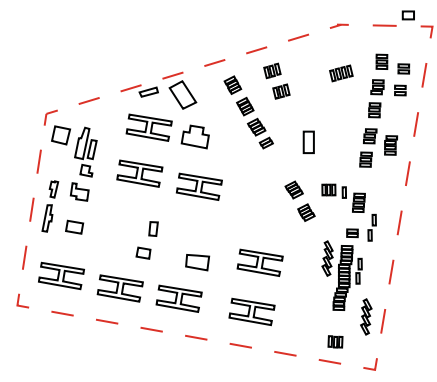

1976 - 2000 HMP Maze

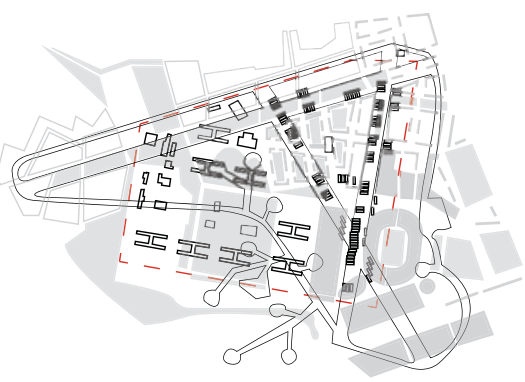

2005 Sports and Recreation Stadium Master Plan

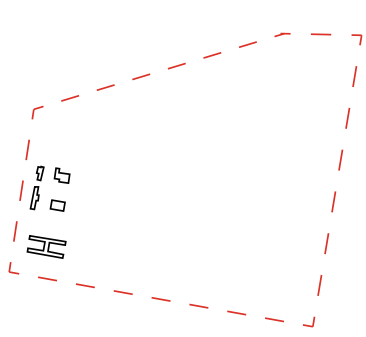

2006 - HMP Maze Site Post Demolition - One H-Block and Prison Hospital Remain

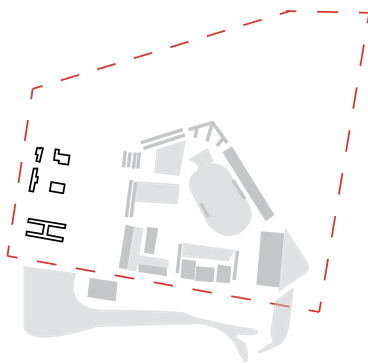

2010 - Plan for Peace and Conflict Resolution Centre and Ulster Agricultural Show arena
The Purpose built HMP Maze is opened on the site and begins housing paramilitary prisoners causing protests.

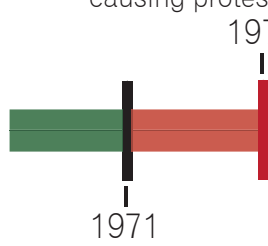

The British

Government begins housing paramilitary prisoners at the disused Long Kesh RAF Base

\section{5}

38 Republican prisoners break out of HMP Maze in the largest prison breakout in British history. 1983

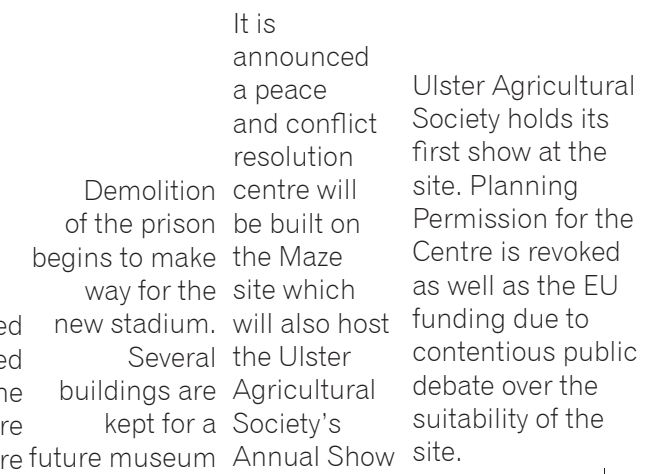

transferred elsewhere future museum Annual Show site.

1983

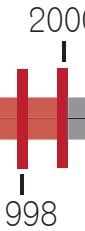

The phased release of paramilitary prisoners buik begins under the stadium on crisis and terms of the Good the prison site a public Friday agreement is announced backlash

the

stadium plan is ruled out

Long Kesh / Maze is one of the world's most politically contentious sites of negative heritage'. Seventeen years following its closure the future of the site is still heavily disputed, despite the fact that much of the former prison has been demolished. Aside from the couple of representative buildings that remain and the fence that still surrounds the site it is unrecognisable as the former prison and could never again fulfil that use.

The site has many different interest groups, all with differing views on the future of the site. Interestingly the idea of developing the site, despite its rather rural setting, has never been taken off the table. Its distinctive and unique sense of place is a 'hook' on which international investment can be hung. Places of negative heritage often fulfil the criteria of international investors looking for sites of distinction in a globalised market where everything is increasingly the same ${ }^{2}$. And while developing the site has been the aim since the prison closed in 2000, the idea of some kind of museum or peace centre has also never been taken off the table. A centre is what makes it distinct and gives it its sense of place. The issue with the creation of a Peace and Reconciliation Centre is that whose history, and whose perspective, is to be told is yet to be established and therefore disputed. Unionists are not interested in seeing Republican Hunger Strikers enshrined whilst Republicans are uninterested in seeing their history equivocated with everyone else's. 


\section{Fritzl House Detailed History}

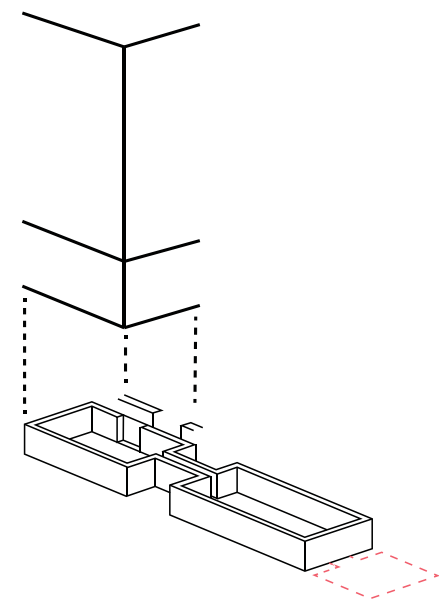

1984 - Elisabeth is imprisoned in the basement extension Fritzl has secretly built. It is behind three locked doors and has a height of only $1.8 \mathrm{~m}$

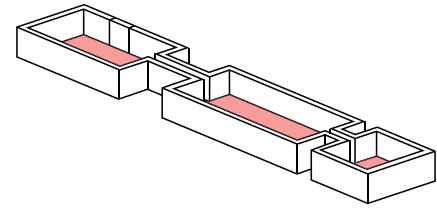

1994 - Elisabeth and her children work to add a third room to their prison.

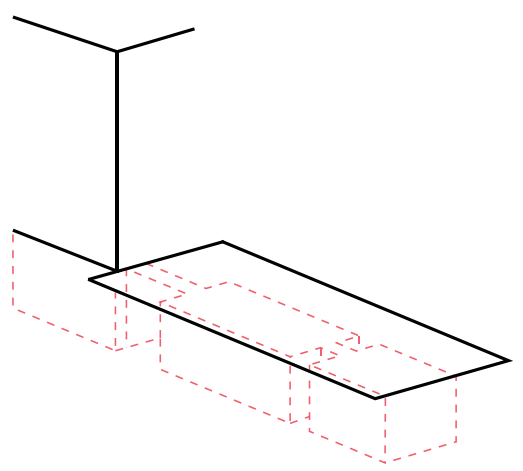

2013 - The basement is filled with concrete and made inaccessible.
Kerstin, the eldest daughter, falls ill and Fritzl at Elisabeth's insistence hospital. Staff immediately to life in prison local developer who

become suspicious of following a 4 day intends to rent the

tricks his daughter into the basement and locks her in the secret room

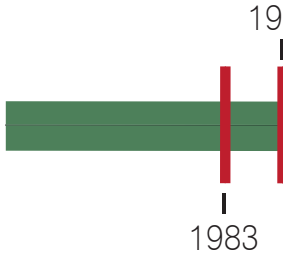

Consent is granted by the local authority for Fritzl to build an extension to the basement. Within the extension he conceals a secret room.

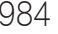
Fritzl's story. trial.

19 April 2008200

\section{6}




\section{The Bain House Detailed Analysis}
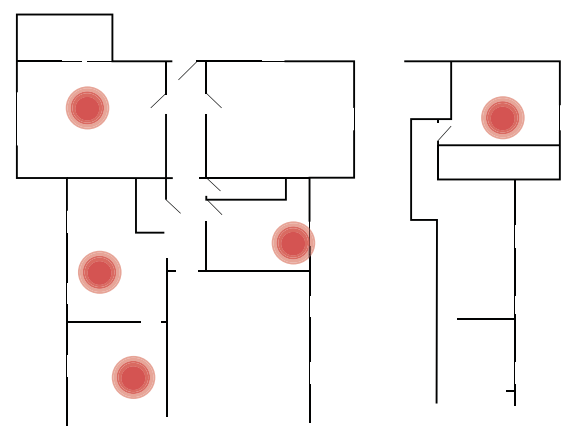

June 201994 - The bodies of five members of the Bain family are discovered in their family home in Dunedin.

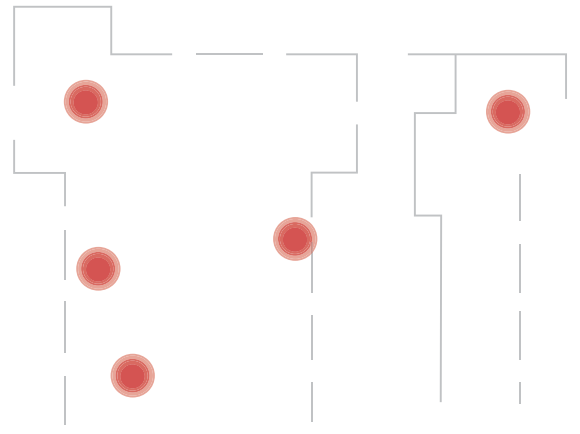

July 71994 - The house is destroyed in a controlled burning, leaving just the outline of the building on the site

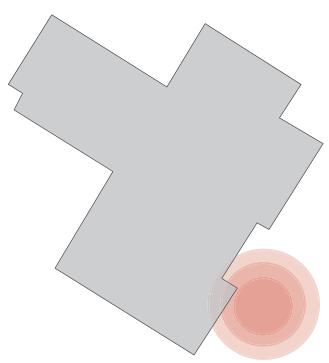

1997 - The Harveys build a single storey house on the property to the south of the old house and facing the street

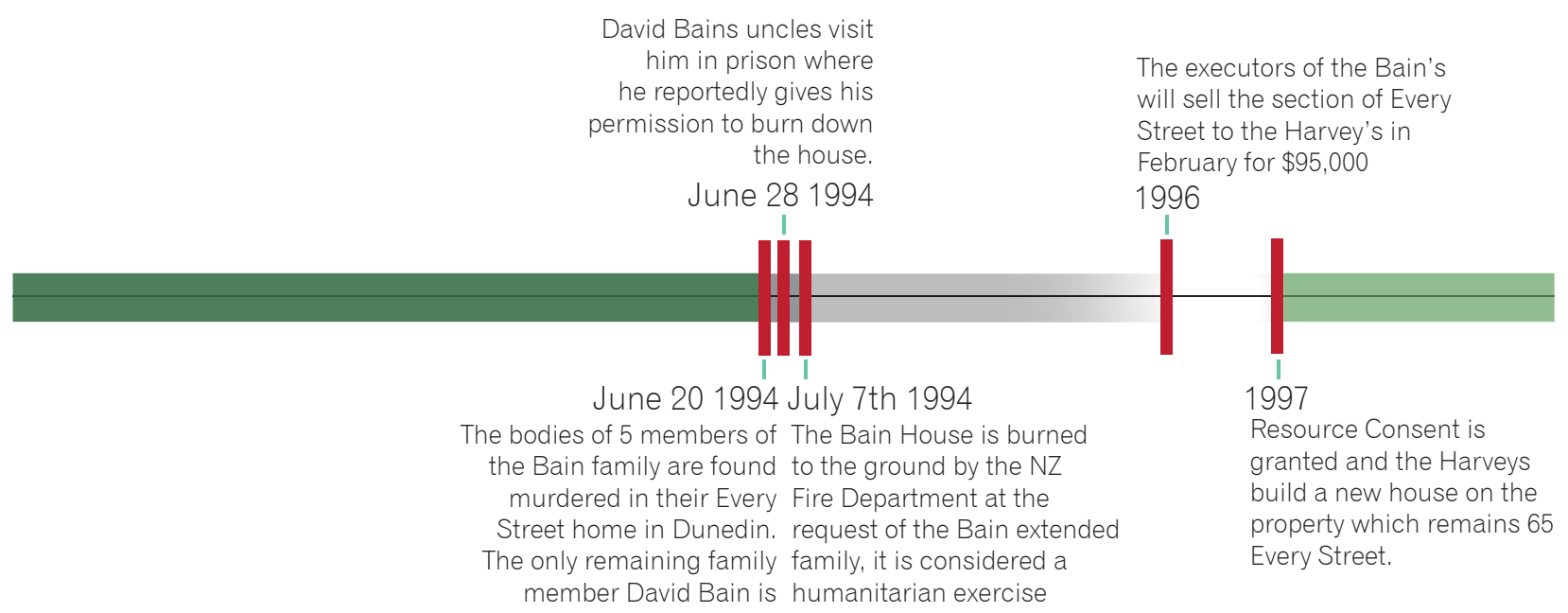

accused of the murders

The destruction of the Bain House occurred within 17 days of the murders. There were many reasons to demolish the house and a controlled burning was seen as a sensible decision. The house was considered dilapidated, cold and dirty and the section was deemed more valuable without the house on it. The family insisted that it was not destroyed for emotional reasons but rather to make way for a quick sale. The police had finished gathering evidence from the house and gave permission for the house to be burned. The New Zealand Fire Service deemed it a humanitarian exercise to undertake a controlled burning of the house, the legality of which is still questioned by many considering who actually owned the house was under question at the time.

Members of the public described the house as a menace which someone was going to take upon themselves to burn anyway. Dunedin was shocked by its third mass murder in five years, David Gray's Crib had been burned to the ground by an arsonist only four years earlier ${ }^{4}$. The attitude in New Zealand at the time seemed to be that the houses should be destroyed, as harbours of bad memories, they had no place in towns and suburbs and there was much communal relief in having them removed. Symbols of pain and death had no place in New Zealand society.

Despite this the current occupant of the site, Lorraine Harvey, who built a house on the site in 1997, slightly to the south but of a similar size and scale to the original house, after buying it from the Bain's and kept the address of 65 Every street said that any time the case is bought up in the media she finds news vans and reporters on her doorstep and often finds people creeping around the property curious about the notorious connotations now attached to the site ${ }^{5}$. 


\section{Sandy Hook Elementary Detailed Analysis}

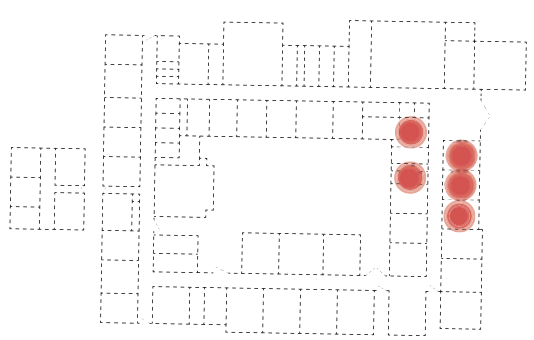

Above: 2012 - Original school plan saw those kills in classrooms directly aside the main entrance, where there was limited security and visibility.

Right: 2016 - The new school places a particular emphasis on security, reorientating it to the nature at the rear of the building with added escape routes and more secure doors

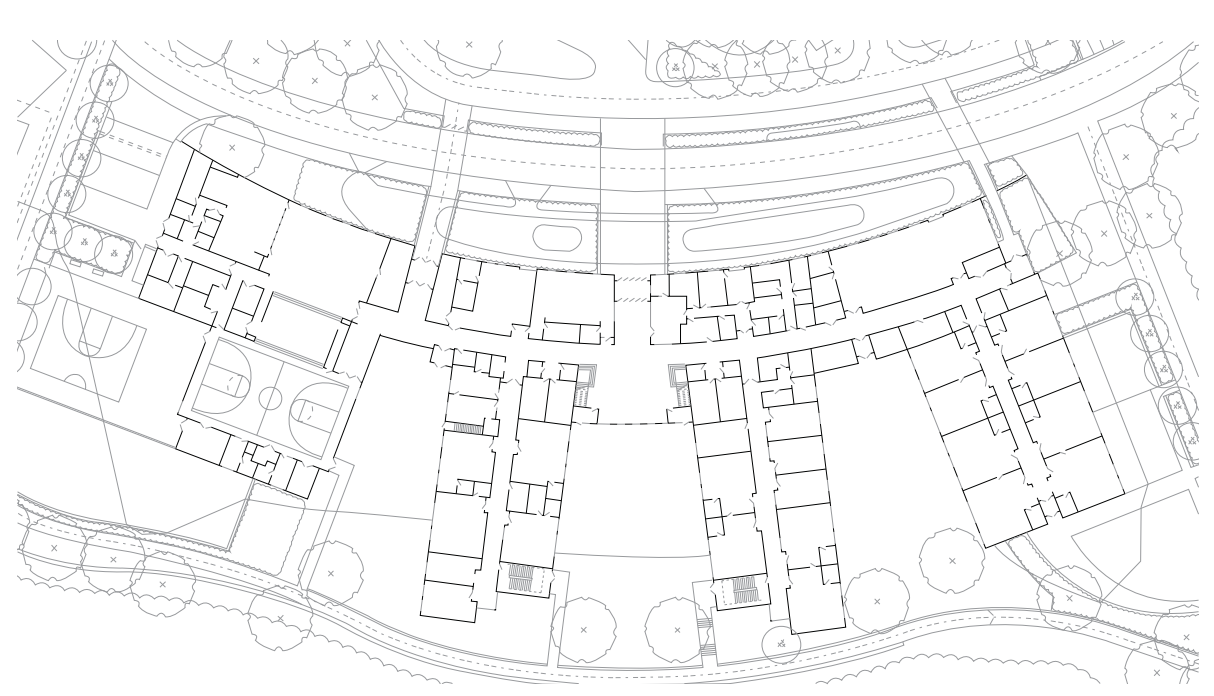

A 28 person taskforce decided unanimously to Planning Permission is granted for a new school to be built on the site 2014

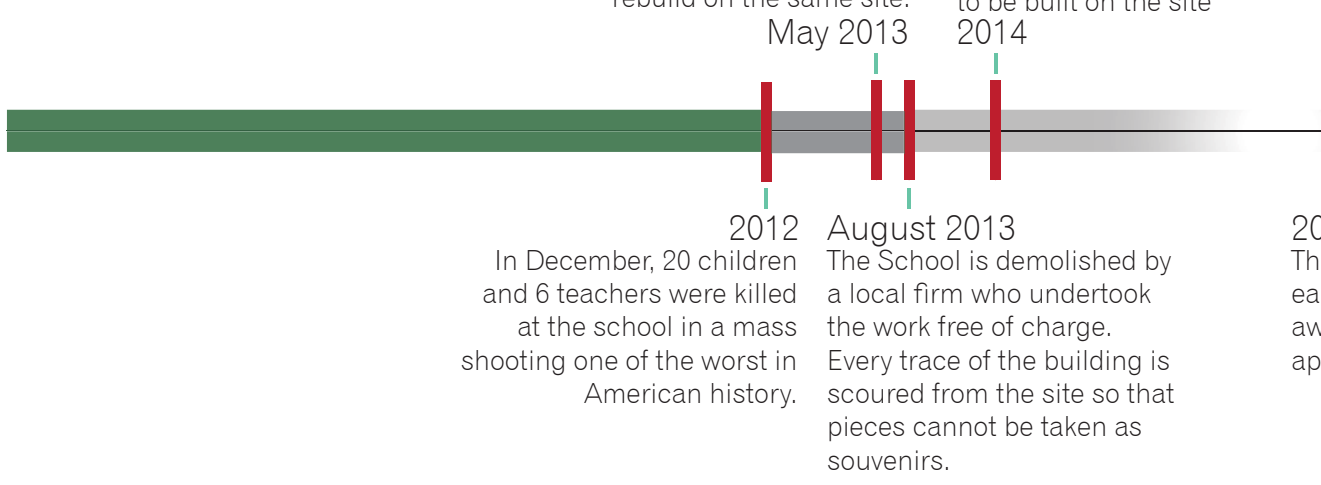

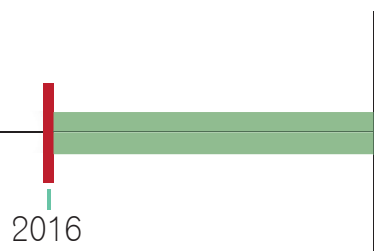

The new school is opened, earning various architecture awards and wide spread approval.

not be taken as ouvenirs.

The demolition of Sandy Hook Elementary School does not fit any kind of pattern of response to school shootings and therefore certain features of the event demand closer attention. Compared to shootings at Columbine (1999) and Virginia Tech (2007), the victims in this case were much younger earning a stronger show of empathy. They were also more dispersed around the building compared to the relatively contained nature of the other two shootings. This was also a small tight knit community who felt unsafe following the shooting, and were uninterested in subjecting their children to the bad memories, that the school held.

There was also an attempt at resilience in rebuilding the school on the old site. The community saw this is as a sign that they had not been broken by the tragedy, that they could rebuild, while some said tearing it down would be victory for evil, in the end the decision to demolish was unanimous, showing a united community spirit to move on and rebuild.

The strong design of the new school, which turns away from the town and towards the wooded nature reserve behind, also speaks to a reorienting of the school's values towards the wild and away from the civilized, finding safety and security in its quiet enclaves and embrace of nature. Security was high priority with maximum escape routes and security doors at the main entrance. Increased visibility and has also been used as a security measure. Does it bridge the gap between past and future? Possibly not, but it would've been difficult to ask a cash strapped public school to do this, however it does provide the elements of a safe haven, a refuge space, of which are vital to parents and children in the wake of tragedy. 


\section{Jonestown Detailed Analysis}

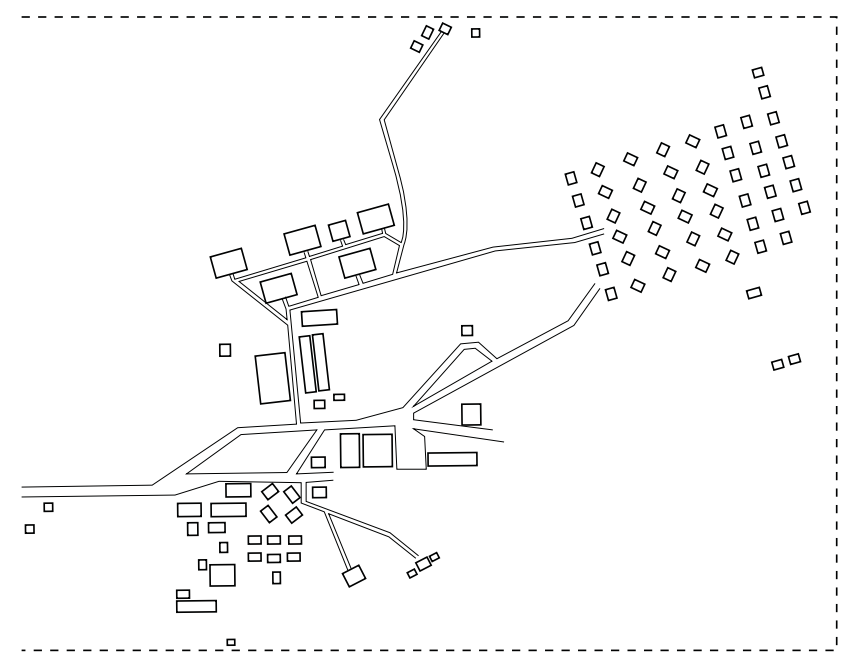

1978 - Jonestown, its border was arbitrary, provided by the surrounding jungle. The buildings were all timber cottages and shacks of which were already breaking down under pressure of mass migration in early 1978.

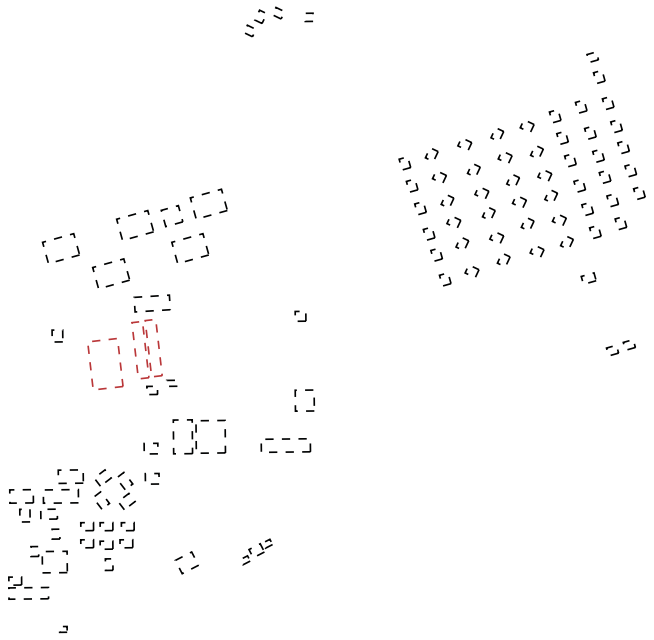

2003 - When a television crew travelled to the site in 2003 on the 25th anniversary they found only remnants of the buildings, most had been reclaimed by the jungle. There was very little evidence of human activity.
Jones negotiated a lease with the Guyana government for 3800 acres of jungle land in North West Guyana. 500 members of the temple migrated to Guyana to establish the commune 1974

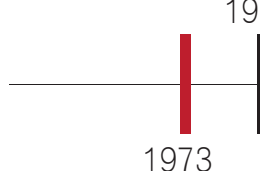

1973

Peoples Temple Agricultural Project based in California pass a resolution to establish an agricultural mission in Guyana in fear or possible persecution in the USA
During a six day siege Jones began preparing the community for an external attack and began planning to once again move the temple.

\section{US Congressman} Leo Ryan travelled to Jonestown with a delegation of 18 on behalf of the concerned relatives.
Guyanese government allowed re-occupation of the site by Hmong refugees from Laos. 1980

September 197714 November 1978

Jonestown like many other cases that fall in the abandoned category, has been abandoned because it no longer serves a purpose. All of those who occupied the site died in the act of 'revolutionary suicide' of 1978. The site lies outside of the public realm and therefore no active measures have been taken to erase the site and no one has taken interest in preserving it.

Abandonment is an inactive and yet effective method of erasure. The breakdown of buildings over time with no upkeep means that they lose a lot of their material worth, and if the site is ever used again, are simply demolished. Though public curiosity has bought news crews to the site over the years, no single interest group has looked to preserve or demolish the site. The fact that it remains hidden and out of the public eye is part of the interest surrounding the site, the invisible in this case, the inaccessible leaving a lot up to the imagination.

Jonestown may be able to break down but on similar sites (rural and built for temporary use) such as Auschwitz, preservationists are having to work hard to preserve the buildings of which were never meant to exist for 60 years. Abandonment is an indeterminate form of erasure which can add complex notions to sites. The breakdown of a site may draw more interest or in the case of Jonestown allow it to fade in the collective memory. 


\section{Charles St. Jail Detailed Analysis}

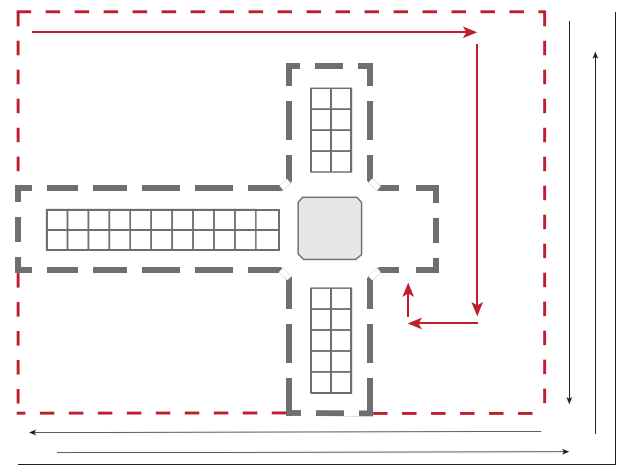

1900 - Charles St. Jail. The building, a large imposing presence in central Boston, is inaccessible to the public.

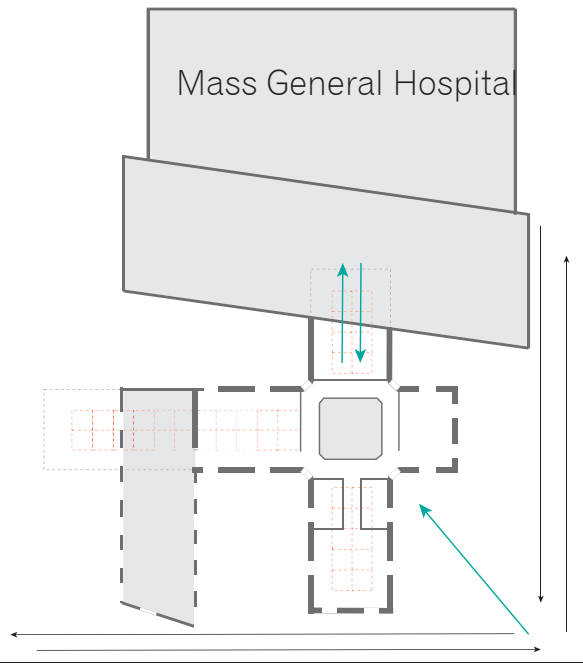

2007 - The Liberty Hotel conversion sees the old jail accessible to the public, be removing its surrounding fence. The additions of Mass Gen Hospital and the accommodation wing also provide access and place the building in scale with its surroundings.

The Jail is purchased by Mass. General Hospital who immediately commission a feasibility

$\begin{array}{rr}\text { to close due } & \text { a feasibility } \\ \text { to inhumane } & \text { report for its } \\ \text { conditions } & \text { reuse }\end{array}$ conditions 1991

Renovation of the building is completed and Liberty Hotel is opened within the former Jail. 2007

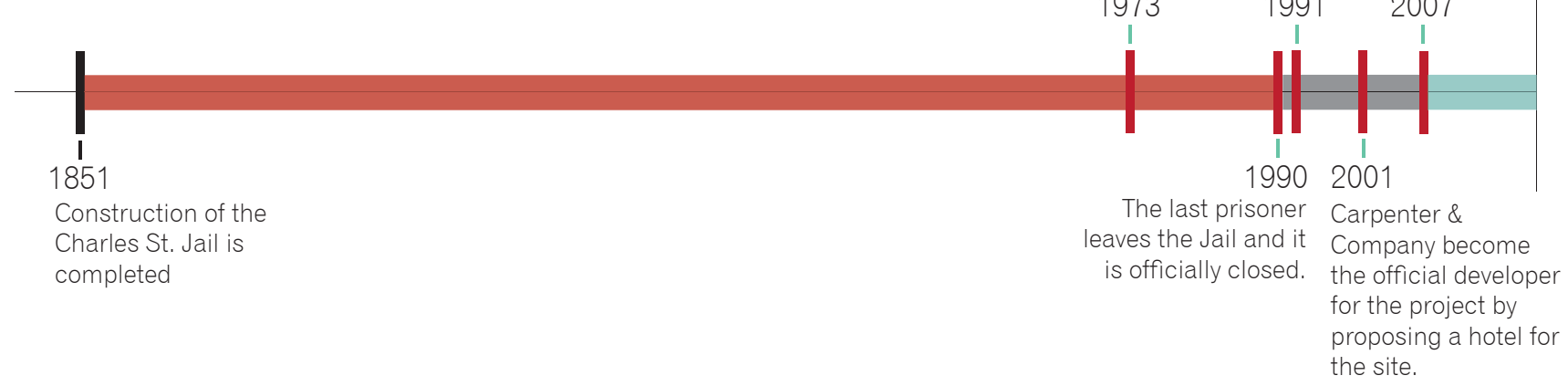

The conversion of the Charles St. Jail to the Liberty Hotel has involved a simultaneous embrace and also subversion of its negative heritage. Its name and public marketing centre around its history as a prison. In many ways the renovation of the Jail also accentuates this identity with the exterior elevation on the street and interior qualities such as the walkways and central hall remaining the same. The aim of this renovation is for the building to still be identified as a prison - whilst simultaneously ignoring the reality of nineteenth century prisons.

Charles St. Jail was condemned in the 1970s for inhumane living conditions, yet took 17 years for all its occupants to be relocated and for the prison to be officially shut down. This history is entirely ignored in the prison's extensive prison museum and all of the actual cells and living realities of the prison have been removed. All of the hotels rooms and suites are housed in the new extension building, meaning the hotels guests do not sleep where prisoners would have slept and the entrance and access to the prison has largely changed, subverting its use.

The prison's economic feasibility is reliant on its now physical attachment to Mass General Hospital who own the prison and site. The hotel was deemed a place where families of patients could stay during treatment. Its physical integration and removal of prison wall is the most prominent symbol of the jails change of use. 


\section{Oakley / Carrington Asylum Detailed Analysis}

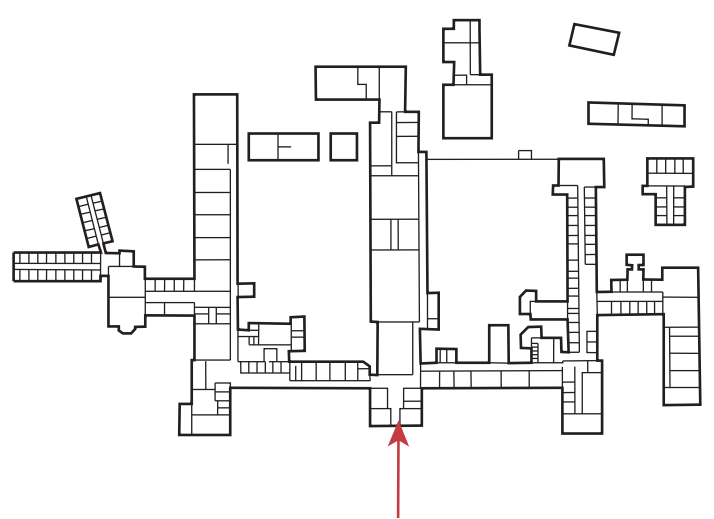

1960 - Oakley Hospital and surrounding facilities, largely inaccessible

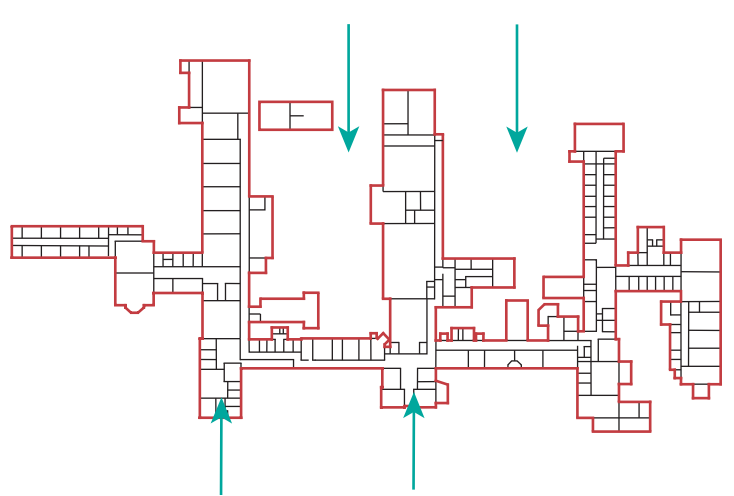

2000 - United Building One, much of the interior of the building has been refitted - some rooms are now inaccessible to users of the building. Accessibility has been increased and it has been reorientated to face the rest of the university.
The Asylum is renamed Oakley Hospital. The complex now includes multiple buildings including a forensic unit.

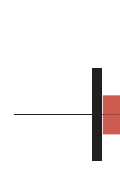

1865

Construction of the

Whau Lunatic Asylum is completed
The Hospital is closed by the Auckland DHB and sold to Unitec whose growing campus backed onto the site
Unitec put the former asylum buildings up for sale suggesting they could be developed as medium density housing 2014

The prompt renovation of Auckland's Oakley / Carrington Asylum relies on it retaining much of its exterior shell, and internal layout for its new use as a university building dedicated to the teaching of architecture and design.

The building retains its external identity and much of its internal layout for use as a school, however some rooms have been entombed or had access removed to its current occupants. Aside from this the building, which was once private and restrictive is now easily accessible, and though retaining its prominent northern face, is orientated towards the site where it is integrated with the rest of the facilities on the site. The renovation and continued use of Building One relies heavily on its inclusion in the Unitec site as shown aside. If Unitec were to discard the building, it would have no conceivable alternative use in its intensely urban setting.

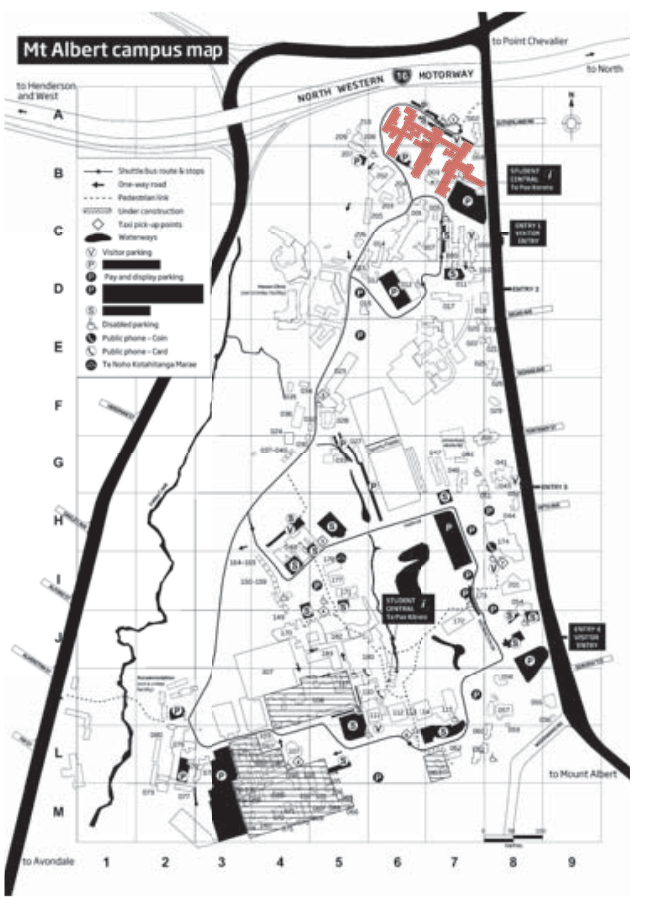




\section{Buffalo State Asylum Detailed Analysis}

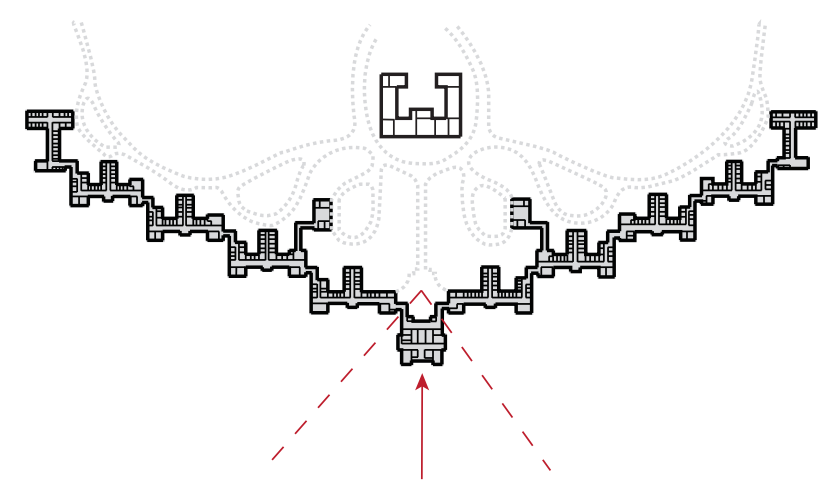

1890 - Buffalo State Asylum, in the Kirkbride Plan, had its wings splay outward to provide constant views outside and a cross breeze of fresh air into the wings, essential elements of Dr. Kirkbride's iconic plan which saw architecture as curative for mental illness.

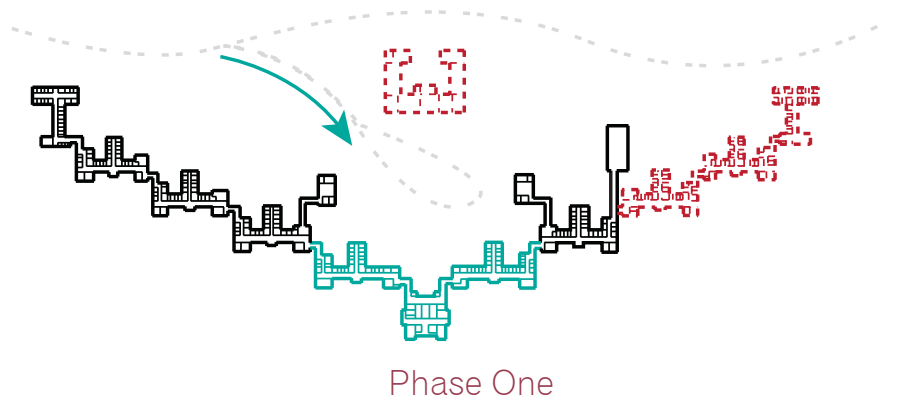

2017 - Phase one of the buildings redevelopment opens with significant changes to the shape of the building and grounds.

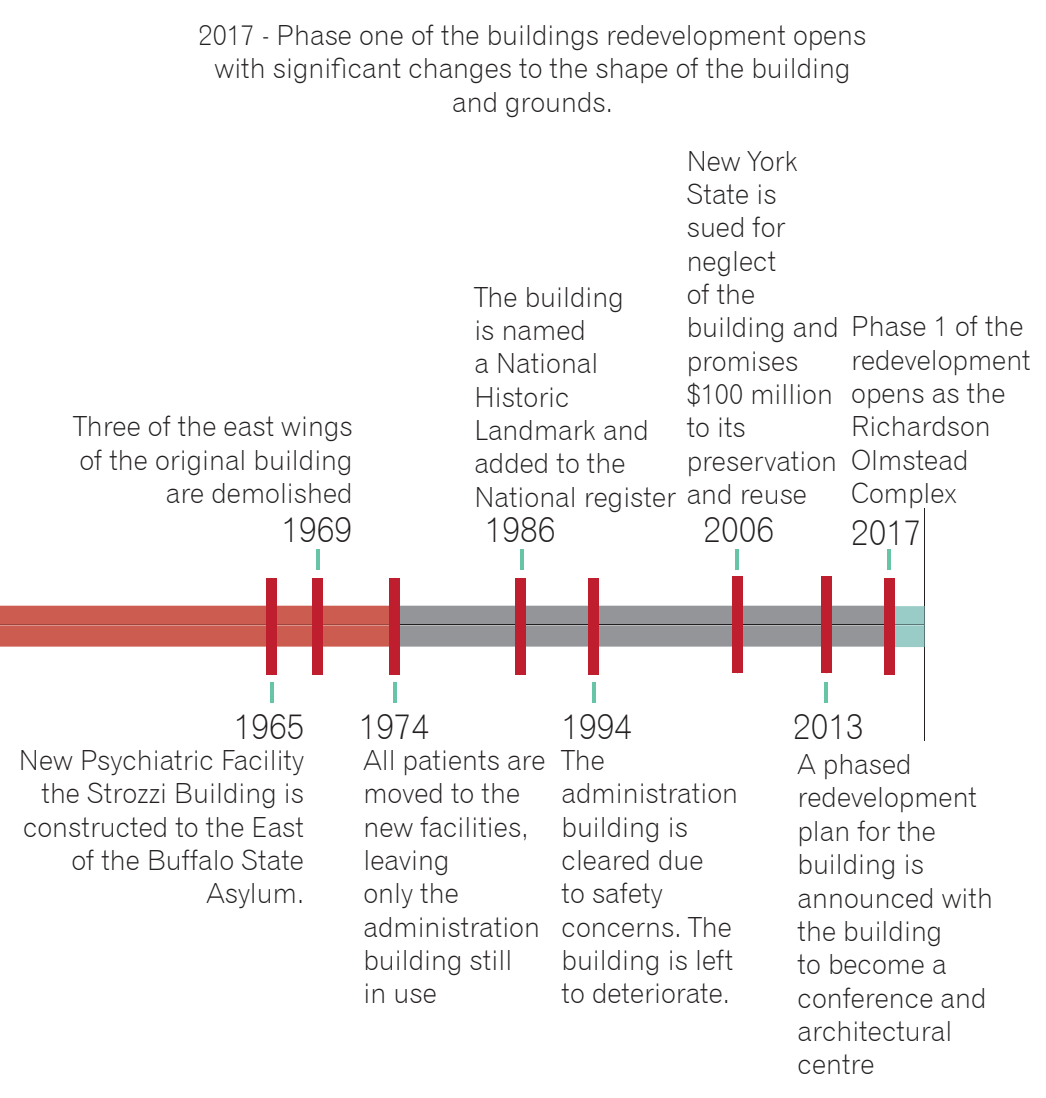

The northern part of the site dedicated to agriculture is reclaimed by Buffalo County for the construction of Buffalo College.

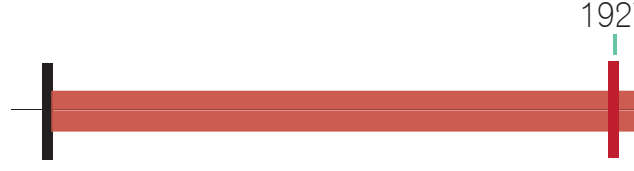

1880

The Buffalo State Frank Law-Olmstead in the Kirkbride Plan is opened to patients while still under construction.
Asylum, designed by H.H. Richardson and

What was once the Buffalo State Asylum and is now the Richardson Olmstead Complex has had to be significantly altered, partially demolished and re-orientated in order to be integrated into its surrounding environment. The building, which once sat on the outskirts of the city, now sits in the heart of its suburbia and backs onto a university, the building needed to be scaled down in order to fit into this far more layered and changing landscape.

Due to the size of the building, its redevelopment has also taken a significant amount of time, and will be completed in stages, the first of which opened in 2017. The entire building which was once oriented towards the river has now been slightly diminished to the eye and turned around so that access is on the opposite side of the building. This completely changes the effect of the wings of the building which now protrude in rather than out removing their elongating effect.

Negative heritage is not referenced at the Richardson Olmstead Complex, the fact that it was once an asylum is not expressed, rather its historical exhibitions and celebrations are to its architect and landscape architect, the aesthetic identity of the building becoming prominent, while the internal layout has been largely reorganised to reflect its new use as hotel and conference centre. The re-orientation of the building means that corridors and rooms have switched sides, so that no guest will sleep exactly where a patient once slept and many rooms are areas are completely inaccessible, doors removed in order to cut off the negative memory from the new enforced identity. 


\section{Lorton Workhouse Detailed Analysis}

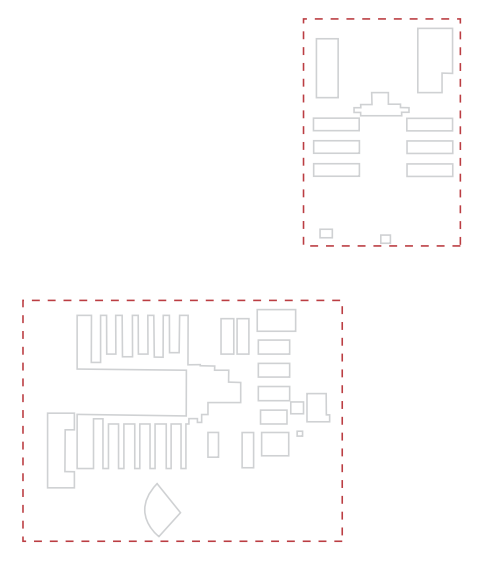

1925 - The Workhouse and Penitentiary side by side on the larger riverside site, each surrounding by its own fence

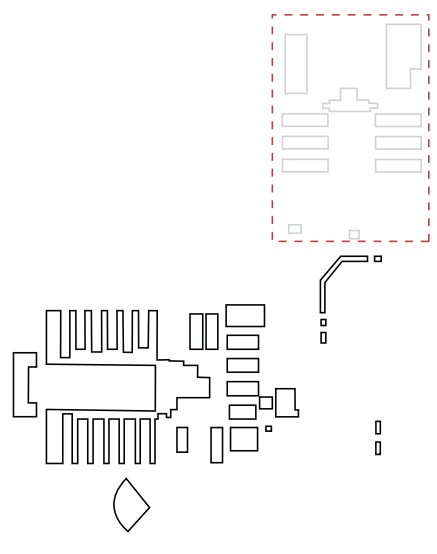

2008 - The Arts Centre opens in the old Workhouse complex, the fencing removed and the site opened to the street. The penitentiary, abandoned remains inaccessible.

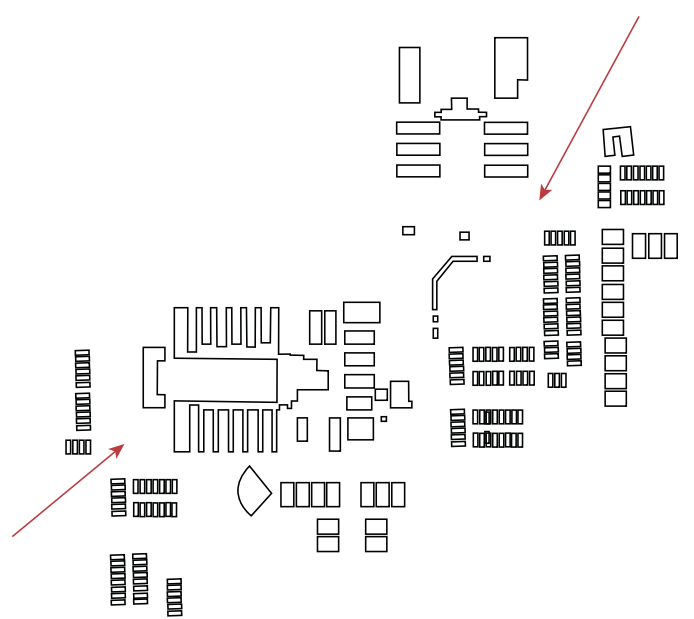

2016 - The Laurel Hill Development, still in construction integrates the two prison sites and their communal uses with a medium density housing development making up the rest of the site.

In 2002 the 3200 acre site was purchased by Fairfax Country, a usability study commissioned and was approved to become an Arts Centre in July 2004 $2002-2004$

In 2016 the Laurel Hill Development was begun on the remainder of the site. including residential and commercial use. 2016

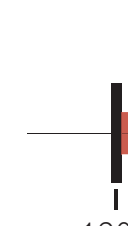

1908

Lorton Workhouse is established by the District of

Columbia on the Occoquan River is closed and the building turned rehabilitation program 1968

The former Lorton Workhouse and Reformatory once centred on an isolated site on the Occoquan River now lies in a newly developed suburban area and has undergone a phased development in order to integrate it into the surrounding landscape and make the site viable for reuse. The Reformatory and Workhouse were closed in 2001 due to poor conditions and the Workhouse was transformed into an arts centre over the following seven years after the site was purchased by Fairfax County. However the Arts Centre was not financially viable on the still rather isolated site. The integration of the site with the surrounding community has involved the inclusion of recreation areas including a baseball field and golf course and an improvement in roads and accessibility to bring people to the site. The Laurel Hill Development begun in 2016 is the final phase using the remaining available land and including residential and commercial zoning so as to improve visitation and use of the site. On a large more isolated site such as this one phasing and integration are important in order to give the site patronage and therefore viability

In the reuse of the site the buildings have retaining their identity with external elevations resurfaced to reflect the modern and creative identity of the new site and the interiors transforming flexibly and easily into corresponding facilities for the Arts Centre. The site has been re-orientated to allow for redevelopment but access and perception of the site remains largely the same. 


\section{Staro Sajmiste Detailed Analysis}

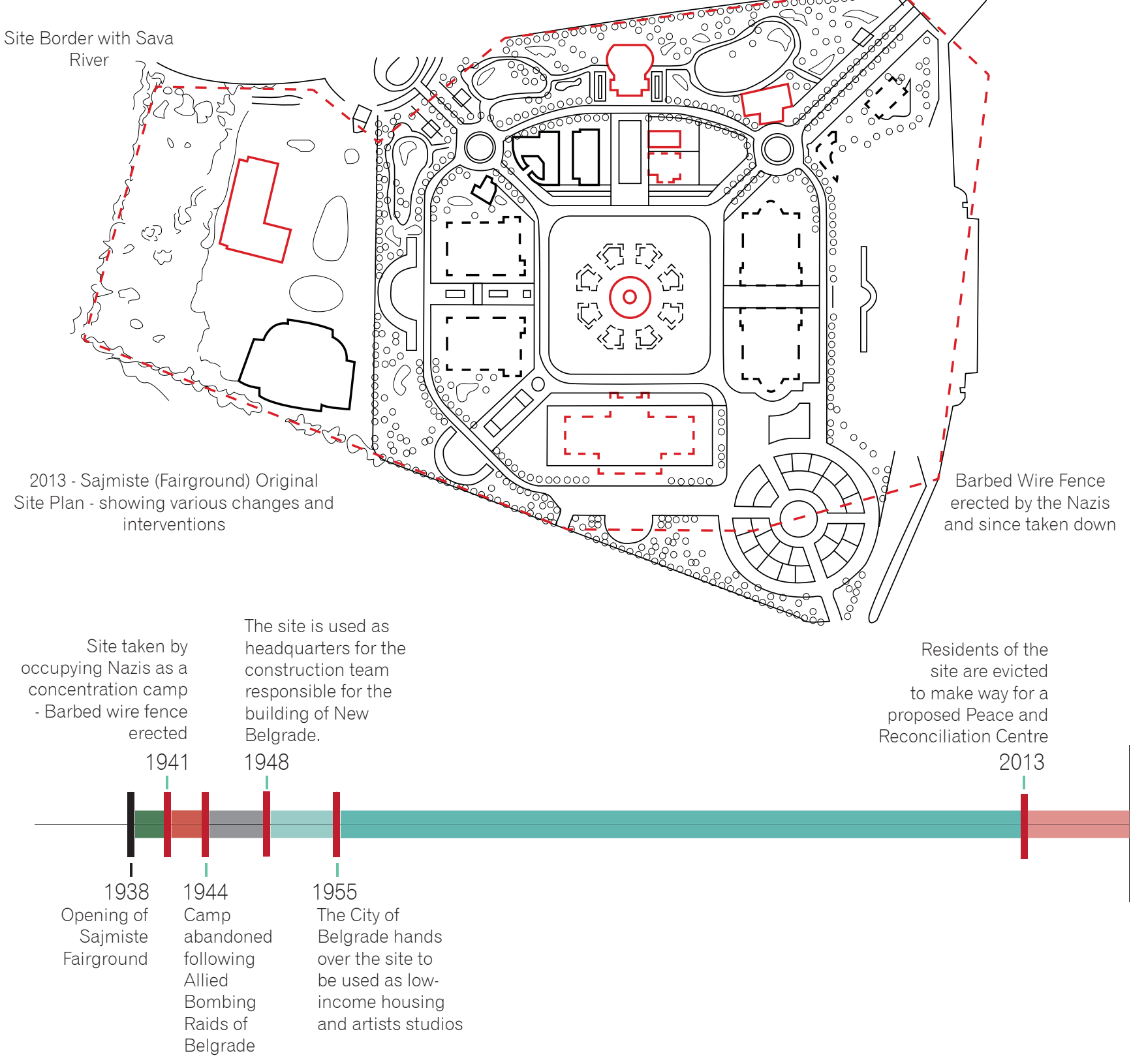

Sajmiste the fairground (now known as Staro Sajmiste - Old Fairground) is a fairground built on the Sava river in 1938, it was transformed into a concentration camp by the occupying Nazis in December of 1941. Thousands were killed or imprisoned on the site until it was abandoned following the allied bombing of 1944. In the 1950s those buildings that hadn't already been destroyed were turned into housing for the socially disadvantaged and over time Staro Sajmiste, which now sits in the centre of Belgrade, has become a hub of commercial and residential activity. Occupation of the site has seen many of the buildings preserved, hindering the realization of postwar redevelopment on the urban site.

In the summer of 2013 those living there were evicted to make way for a peace and reconciliation centre, The fact that Belgrade was the only capital city in Europe with the remains of a concentration camp not commemorated troubles Serbia's entry into the European Union, where under the Stockholm declaration all sites central to the Holocaust must be commemorated. However, arguably, a museum commemorating genocide cannot be built on a site forcefully cleared without compromising its purpose. Those living there have played a part in its preservation, without them the site with all its remnants would not exist, and it would not have been integrated into the city fabric.

The site had a radial layout, ideal for the display of digital technology as well as camp surveillance and though not so immediately obvious now with the heavy vegetation growth the central observation tower still exists. The fact that the site is open and accessible is central to its integration. The occupying Nazis built a barbed wire fence around the site in 1942 and with the erection of a museum in need of security, the fence may return, a symbolic gesture to the integration and accessibility of a resilient site. 


\section{Erasure Techniques}
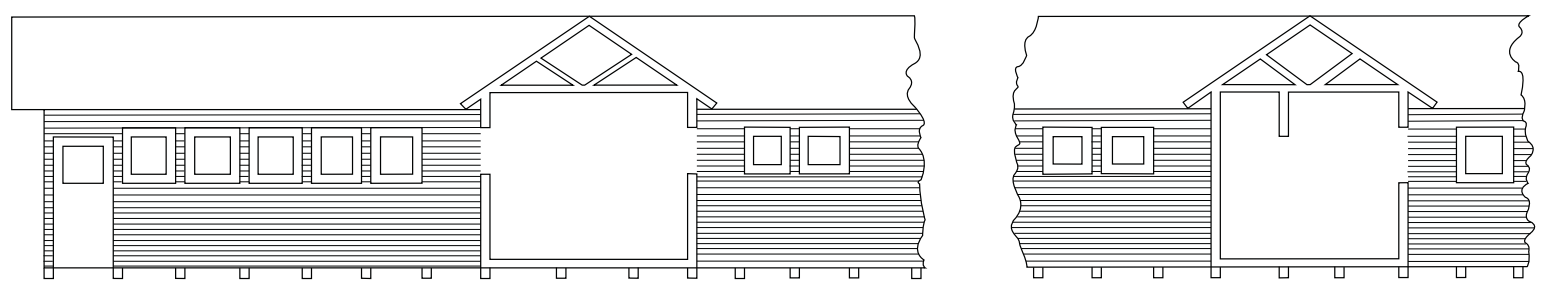

\section{Demolition - Total \& Selective}

Demolition is a simple and common form of eradicating a building and in this case means the use of bulldozer or the very active dismantling of the building. There are two types

- A Total demolition is the complete eradication of the building, with no physical remnant remaining.

- Selective demolition, is the demolition of certain parts of a building or a site that are deemed to particularly harmful to future development or are particularly painful reminders of a negative history. With the aid of machinary selective demolition is common and easy to undertake.

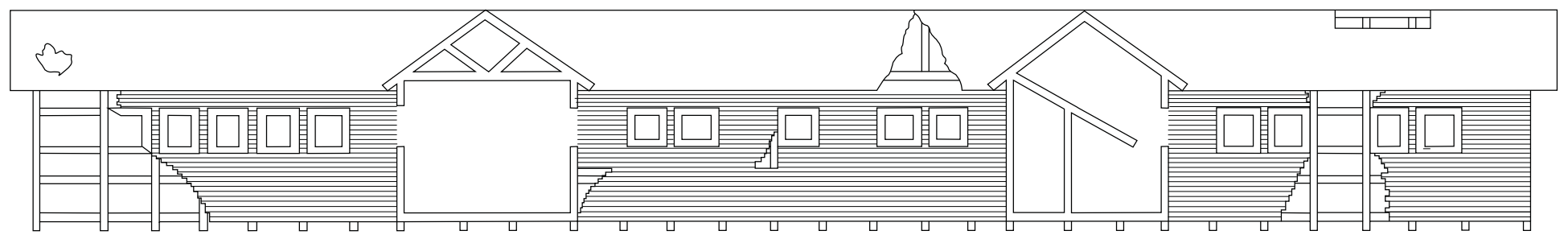

\section{Abandonment}

Abandonment is genally an indeterminate and inactive method of destroying a building. However any kind of abandonment, the end of occupation and therefore the end of the upkeep of a building is likely to begin its destruction. After a certain amount of time abandoned many buildings are deemed uninhabitable, or not sufficiently financially viable to restore and are demolished in order to finish the erasure process and remove an 'eyesore' from the landscape.

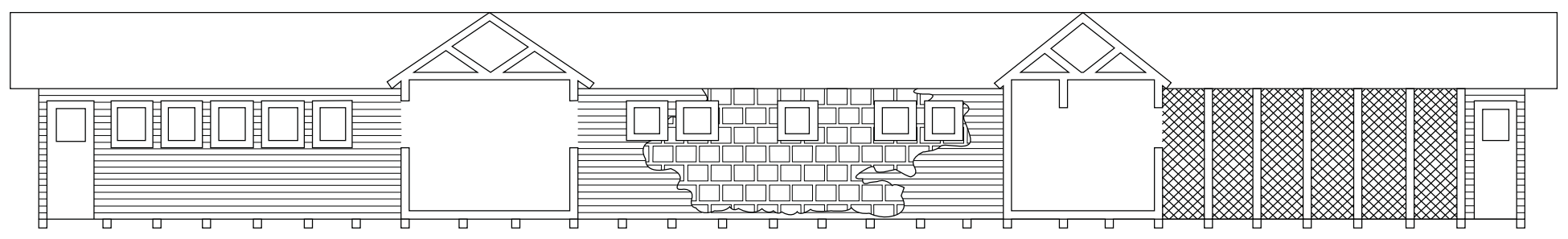

\section{Re-Surfacing}

Re-surfacing of a building covers a number of individual methods across a range of scales, from a new coat of paint to a complete change in cladding. Re-Surfacing aims to alter the appearance of a building, allowing it to take on a new identity and subverting its old one. This can also change the dimensions of the space when walls are re-clad in glass increasing visibility and the overall intension of the space.

\section{Filling In}

Filling in involved the filling in of space with concrete or another similar material in order to remove the space and make it a solid form. 


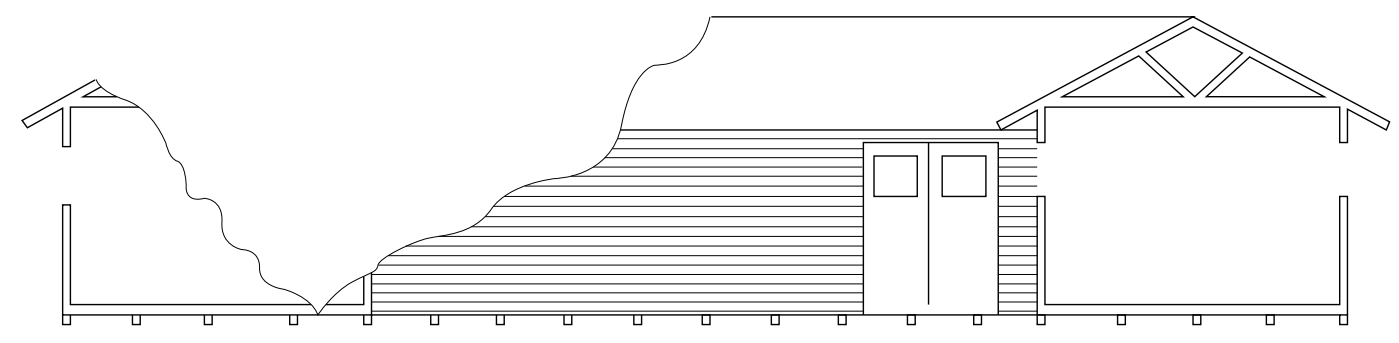

\section{Burning}

Burning is a total and indeterminate method of eradicating a building. It is used by those who are determined to see every last remnant of a place destroyed. It is a method often used by a community or those outside authority as is a method easy to generate and inflict.

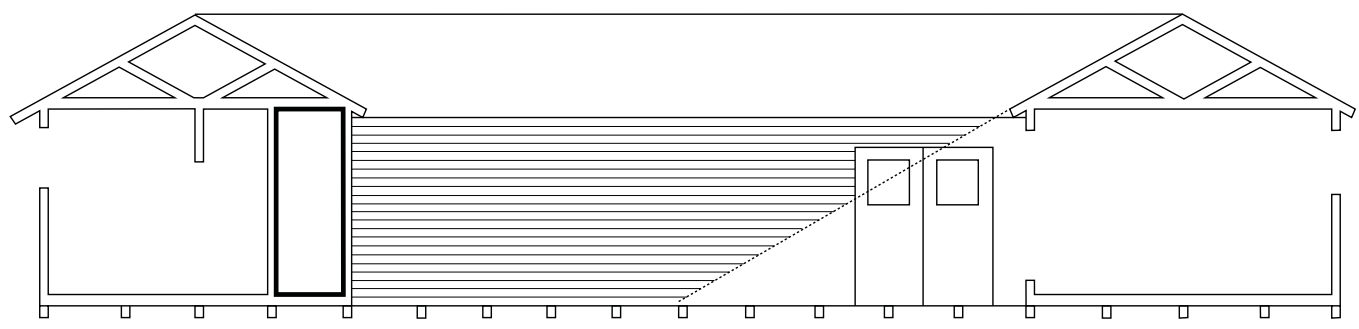

\section{Entombment}

Entombment is the active technique of removing access to a space, making the interior inaccessible so it can no longer be occupied. This is rarely used, when space can be altered and destroyed to have a similar erasing effect.

\section{Increased Visibility}

Increased visibility is the opening up of enclosed rooms or spaces, increasing visibility within a room or to the outside by inserting glass instead. This changes the experience of the space and its ability to hide or enclose negative memory 